$1-1-1961$

\title{
Marketing practices and procedures of Northeastern livestock producers
}

Kenneth D. McIntosh

Follow this and additional works at: https://researchrepository.wvu.edu/ wv_agricultural_and_forestry_experiment_station_bulletins

\section{Digital Commons Citation}

McIntosh, Kenneth D., "Marketing practices and procedures of Northeastern livestock producers" (1961). West Virginia Agricultural and Forestry Experiment Station Bulletins. 457.

https://researchrepository.wvu.edu/wv_agricultural_and_forestry_experiment_station_bulletins/432 @ WVU. It has been accepted for inclusion in West Virginia Agricultural and Forestry Experiment Station Bulletins by an authorized administrator of The Research Repository @ WVU. For more information, please contact ian.harmon@mail.wvu.edu. 
West Virginia University Libraries

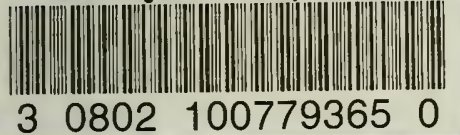


Digitized by the Internet Archive in 2010 with funding from Lyrasis Members and Sloan Foundation 


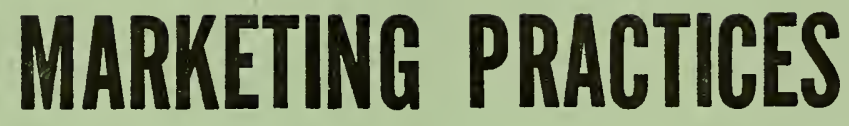
AND

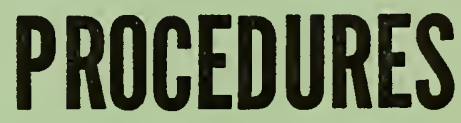

OF

\section{NORTHEASTERN LIVESTOCK PRODUCERS}

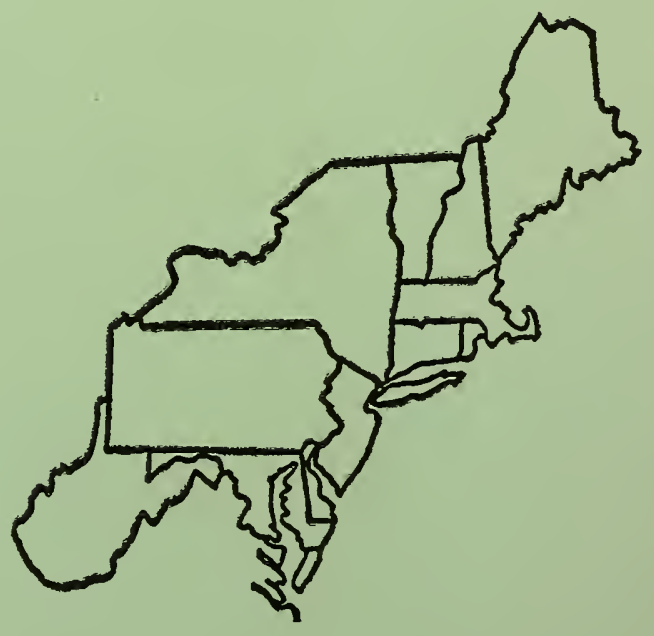

\section{WEST VIRGINIA UNIVERSITY} AGRICULTURAL EXPERIMENT STATION 


\title{
THE AUTHOR
}

Kenneth D. McIntosh is Assistant Agricultural Economist in the West Virginia University Agricultural Experiment Station.

\author{
WEST VIRGINIA UNIVERSITY \\ Agricultural EXPERIMENT Station \\ College of Agriculture, Forestry, and Home Economics \\ A. H. Vanlandingham, Director \\ MoRgantown
}




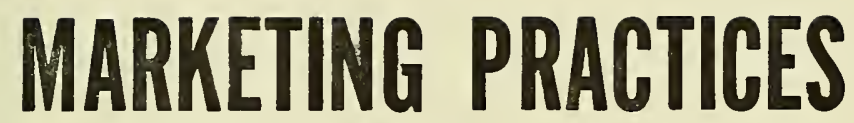

AND

PROCEDURES

OF

\section{NORTHEASTERN LIVESTOCK PRODUCERS}

by

KENNETH D. McINTOSH

WEST VIRGINIA UNIVERSITY

AGRICULTURAL EXPERIMENT STATION 


\section{CONTENTS}

Foreword

iii

Summary iv

Introduction

General Characteristics of Northeast Farmers

Income Sources and Type Farms

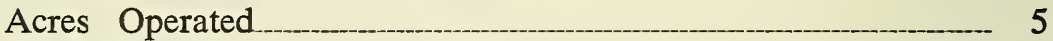

Road Type

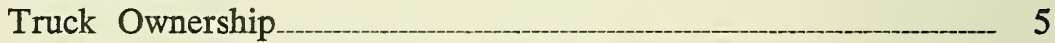

Number and Kind of Livestock on Farms

Membership in Herd Improvement Associations______________ 9

Distance to Livestock Dealers and/or Auctions________________ 9

Livestock Sales______________ 12

Type and Number Sold 12

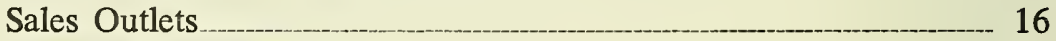

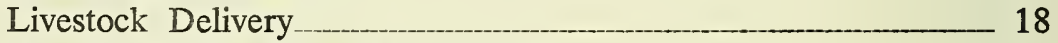

Livestock Market News Information.___ 22

Reasons for Selling Livestock 24

Condition of Animals Sold _ 28

Inspection of Livestock Sold______ 30

Age of Livestock Sold 33

Seasonality of Sales_________ 35

Lot Size 35

Type Sale 35

Farmer's Opinions About Choice of Outlet,

Prices Received, and Marketing Services___________________ 38

Livestock Procurement 46

Number and Sources of Livestock Purchased 46

Intended Use and Reasons for Purchasing Livestock ___ 51

Knowledge of Past History-Inspection $\quad 55$

Age of Livestock Purchased___ 58

Seasonality of Purchases__ 58

Lot Size 61

Type Purchases 64

Health of Livestock Purchased_____ 64

Satisfaction with Livestock Purchased 66

Farmers' Attitudes on Their Marketing Problems_________ 66 


\section{FOREWORD}

This report is a descriptive summary of livestock marketing activities by Northeastern farmers, including both buying and selling. It is a companion report to other surveys already published dealing with auction markets, livestock dealers, and slaughter plants. These four reports cover the full range of livestock marketing activities in the Northeast and have served to focus attention on areas needing more thorough or detailed study. These studies were made cooperatively by the Northeastern Agricultural Experiment Stations and participating agencies of the United States Department of Agriculture.* The objective of these studies was to develop ways to improve the efficiency of livestock marketing.

This report, the last of the series under the project, is based on survey data obtained from 1,300 Northeastern farmers. The cooperating agencies included:

State Agricultural Experiment Stations
Connecticut
Delaware
Maine
Maryland
Massachusetts
New Hampshire
New Jersey
New York
Pennsylvania
Rhode Island
Vermont
West Virginia

\section{United States Department of Agriculture}

Agricultural Marketing Service

Farmer Cooperative Service

State Experiment Stations Division

Regional Coordinator

\section{Administrative Advisor}

- This report represents one area of research carried out under Northeast Regional Livestock Marketing Research Project NEM-7, "Improvement of Market Procedures and Outlets for Northeastern Livestock with Emphasis on Dairy Animals." 


\section{SUMMARY}

\section{Characteristics of Farmers}

The results of a farm survey taken in Northeastern United States during 1955 indicate that 62 per cent of the farmers interviewed were dependent upon dairying as their principal source of income. Work-offfarm provided the major source of income for 16 per cent of the farmers and another 8 per cent depended primarily upon income received from the sale of livestock.

The average acreage for all farm types was 128 . Livestock and dairy producers operated the largest number of acres, and poultry farmers and retired workers operated the smallest number of acres.

About half of all farmers surveyed lived near a hard-surfaced road, and about two-thirds owned a truck. Of those owning trucks, approxi-

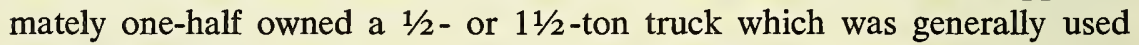
in their livestock operations. Twenty per cent of the farmers owning trucks were not able to indicate the size of their trucks.

Most farmers lived within 30 miles of the nearest livestock dealer and/or nearest livestock auction.

When farms were classified by type on the basis of the principal source of income, then examined for typical numbers of livestock, it was found that a typical farmer had no hogs, beef-type cattle and calves, sheep and lambs. This was true for livestock, dairying, and indeed each of the 10 types of farm. On all typical farm types except livestock there was at least one to five dairy animals. Thus, in addition to dairy farmers, many Northeastern farmers were engaged in dairying to some extent. On typical dairy farms, there were 31 to 50 dairy animals.

\section{Sales of Livestock}

\section{TYPE AND NUMBER OF ANIMALS}

Livestock and dairy-type farmers sold more than two-thirds of all animals sold and their sales were significantly larger than those of other farm types. During 1954, producers sold about three times more dairytype cattle $(4,885)$ than beef-type cattle $(1,643)$. Dairy-type calves sold $(12,268)$ were approximately 30 times greater than the number of beef-type calves sold (391). The number of hogs and sheep sold was quite low and, for all practical purposes, can be considered insignificant. The average number of animal units sold for all farm types was 8.0. Livestock farmers ranked first, averaging 21.2 animal units sold, while dairy farmers ranked second with an average of 7.8 animal units.* 


\section{SALES OUTLETS}

About half of all the livestock sold were marketed through auctions, one-fourth to dealers, and the remainder through several minor outlets. When reduced to animal units the numbers sold through auctions were significantly larger than the numbers sold through all outlets except dealers. The differences in numbers marketed through auctions and dealers were not statistically significant.

\section{SOURCES OF LIVESTOCK INFORMATION}

The data reveal that two-thirds of all Northeastern producers interviewed received livestock price information regularly. In order of importance, newspapers, radio, and farm magazines were listed as the sources of information. Three-fourths of those receiving information indicated that it met their needs. One-fourth of the respondents stated positively that they were satisfied with the present available information, while 15 per cent indicated a positive need for more information.

\section{REASONS FOR SELLING LIVESTOCK}

The most commonly stated reason for selling livestock was "ready for market." A large number of the bob calves were sold because the parents were poor producers, they were bull calves and farmers had no desire to raise them, or farmers obtain more income from selling milk as milk rather than marketing it through calves. About 13 per cent of the livestock were sold because they were culls. Low production, disease, old age, failure to breed, and difficulty in handling were some of the stated reasons for culling herds.

\section{CONDITION-FINISH-INSPECTION-AGE}

About half of the cows and heifers were sold when carrying calves. Slightly more than half of the cows and heifers were sold during the lactation period. Milk and butterfat production records were known for less than 10 per cent of all dairy cows sold.

About half of the respondents indicated they had a feeding program for finishing slaughter cattle. Most commonly it was pasture alone or in combination with some grain. Less than 15 per cent of the producers finished livestock on grain alone, but for those who did, the period of feeding was 150 or more days.

* Farmers not knowing or not giving their principal source of income were actually second ranking, but there were only six of these and they were not considered as a significant and reliable farm type. 
Less than 15 per cent of the livestock were inspected by veterinarians before being sold. Only 2 per cent of all producers stated that they "filled" their livestock in the immediate 12 hours before selling them.

About 60 per cent of the dairy calves were less than five days old when sold. Half of the hogs were sold as feeder pigs and half as slaughter hogs. Practically all beef-type cattle were one year old or more when sold. Two-thirds of the lambs sold were between the ages of three and six months.

\section{SEASONAL PATTERN-LOT SIZE-TYPE SALE}

For all livestock there was a minor peak in the numbers marketed during the spring months of March and April. During September, October, and November livestock marketings increased substantially to an annual peak and then declined in December, January, and February to their annual low.

In general, replacement stock and slaughter cattle were sold in lots containing one animal, while calves, lambs, and hogs were sold in either single or multiple numbers per lot. Approximately 60 per cent of the cattle and calf lots contained one animal each, and about 40 per cent of the hog and sheep lots contained five or fewer head.

Although there were variations noted among states, more than 60 per cent of all dairy cattle were sold by the head and more than 95 per cent were sold for cash.

Practically all lots of livestock were sold "as is." Less than 5 per cent of all lots had any type of written or oral description concerning health, breeding, or production of the animals.

\section{FARMERS' OPINIONS ABOUT CHOICE OF OUTLET,}

\section{PRICES RECEIVED, AND MARKETING SERVICES}

Farmers stated that "convenience" was the most important reason for selling livestock to or through all outlets except terminals. "Price" was listed as the second most important reason for influencing farmers' choice of market. "Habit" was the only major reason given for selling livestock to certain outlets.

Producers registered overwhelming satisfaction with both market price and market services regardless of the outlet used. Where dissatisfaction was noted with market prices it most often occurred when animals were sold through auctions or private sales. Marketing services were most unsatisfactory when livestock was sold through auctions, to relatives, local homeowners, and through breed dispersals.

\section{NUMBER AND SOURCE OF LIVESTOCK PROCUREMENTS}

Most of the livestock purchased during 1954 were replacement dairy animals. Very few hogs and sheep were purchased. For all respondents 
the average number of animal units purchased was slightly greater than 2.0. Dairy farmers bought significantly more animal units than all types of farmers except livestock farmers.

Purchases from dealers ranked first, with 32 per cent of all animal units bought from this agency. Procurements from other farmers ranked second, accounting for 30 per cent of all animal units, and auction purchases ranked third, amounting to 20 per cent of all animal units bought. At the 5 per cent level of significance, there was no significant difference in the animal units purchased from these three sources.

\section{INTENDED USE AND REASONS FOR PURCHASING LIVESTOCK}

Approximately 85 per cent of the dairy-type cattle were bought for replacements, and the same percentage of beef-type cattle and calves were bought for feeding. Three-fourths of the hogs were bought for feeding and half of the sheep were purchased for herd replacements.

More than three-fourths of the respondents indicated a preference for raising their own replacements. The most commonly given reason for this preference was "knowledge of health and animal characteristics." "Obtain better stock" and "cheaper to raise than buy" were also stated as reasons. Essentially these same reasons were listed by those respondents who preferred to buy their replacements.

\section{KNOWLEDGE OF PAST HISTORY- \\ HEALTH-CONDITION-FINISH-INSPECTION-AGE}

Producers knew the previous owners of about half of the dairy-type cattle and calves purchased, 43 per cent of the hogs, 55 per cent of the sheep, and 16 per cent of the beef-type cattle and calves.

Annual milk production records were known for 16 per cent of the dairy cattle purchased by dairy farmers, and butterfat records were known for 5 per cent of the dairy cows purchased.

About 40 per cent of the cattle and calves bought were known to have been inspected by veterinarians at the time they were purchased. Since many of the Northeastern auctions require veterinary inspection of livestock, and more than half of the farmers do not know about such inspections at auctions, the proportion of replacements that were checked by veterinarians is likely higher than that indicated by producers.

Approximately 56 per cent of the dairy animals were over two years of age when purchased and 20 per cent were under three months of age. Practically all beef-type cattle and calves were six months or older when bought. Most of the hogs were bought for feeding and were under three months of age, whereas sheep were bought largely for replacements and were one year old or more when purchased. 


\section{HEALTH OF ANIMALS PURCHASED}

Farmers stated that 20 per cent of all sheep, cattle, and calves bought suffered disease or other trouble, such as failure to breed. The rate was only 2 per cent among hogs. In spite of diseases and other trouble, farmers registered satisfaction with more than 90 per cent of all livestock purchased.

\section{SEASONAL PATTERN-LOT SIZE-AND TYPE PURCHASE}

The greatest number of livestock was bought during the months of June, September, and October. Purchases were lowest during January and generally increased steadily through June. During July purchases decreased substantially, but from this low they increased rapidly to an annual peak during the month of October.

The typical lot size for all stock purchased was one head. Almost 60 per cent of the cattle and calves were purchased in lots containing one or two head. Hogs and sheep lots were slightly larger with approximately two-thirds containing five or fewer head.

More than 90 per cent of the animals were bought by the head. Credit purchases accounted for only 5 per cent of all cattle and calf lots and none of the hog and sheep lots.

\section{FARMERS' ATTITUDES ON LIVESTOCK MARKETING PROBLEMS}

When asked to state their major marketing problems, two-thirds of the Northeastern producers replied that they had no problems or they failed to answer the question. One-fourth of the farmers had "felt problems" in the area of prices and competition, and a small percentage had problems in the area of inadequate market facilities and services. 


\section{Introduction}

The primary objective of this report is to indicate the livestock marketing practices and procedures followed by producers in the Northeast. Livestock production and marketing in Northeastern United States is comprised largely of dairy cattle production and the disposition of cull dairy animals and calves. Altogether, cattle and calves kept for milk (5,$380,000)$ outnumber all other cattle and calves $(1,043,000)$, approximately 5 to $1 .^{\prime}$ This area is one of the most important dairy regions in the nation with approximately 16 per cent of all dairy cattle located in the twelve states. ${ }^{2}$ West Virginia is the only Northeastern state where the number of cattle and calves kept for milk does not exceed the number of other cattle and calves.

The Northeast has long been a deficit meat producing region, with considerable quantities of meat imported from other regions. In 1957, the estimated meat requirements for people in the area was 4,453,955,400 pounds of beef and veal, $2,935,887,000$ pounds of pork, and $200,499,600$ pounds of lamb and mutton (Table 1). During the same year Northeast farmers marketed $853,971,250$ pounds of beef and veal, $248,557,240$ pounds of pork, and $22,209,960$ pounds of lamb and mutton. Thus, if it is assumed that all the meat marketed by Northeast farmers was consumed in the region, it was equivalent to about 19 per cent of the beef and veal, 9 per cent of the pork, and 11 per cent of the lamb and mutton consumed in the Northeast during 1957.

While the production of swine, beef-type cattle, sheep and lambs is not very large when compared to other regions and states, it is quite important to those producers who depend upon the production of meat animals for their cash income. This is especially true in West Virginia and in certain localities in Pennsylvania, Maryland, and New York. At the same time, the value of cull dairy animals should not be minimized, as this source of income often means the difference between profits and losses for dairy farmers.

During 1958 the value of all cattle and calves marketed by Northeast producers was estimated at $\$ 283,677,000$. Swine marketings were valued at $\$ 61,565,000$, and sheep and lamb marketings were estimated at $\$ 8,144,000$. $^{3}$ Altogether, the money received from sales of livestock added one-third of a billion dollars to the incomes of Northeastern

1 Compiled from Livestock and Poultry Inventory, January 1, 1959, Number, Value and Classes. USDA, AMS, Crop Reporting Board, February 13, 1959. The Crop Reporting Board separates cattle and calves into two major categories; those kept for milk and others. Essentially these categories refer to dairy-type cattle and beef-type cattle, respectively. It is recognized, however, that these delineations are not precisely accurate and there is some overlapping between categories. It would seem that the difference is not very great, but to the extent that it is the use of dairy cattle for animals kept for milk and beef-type cattle for others is in error.

2 Ibid.

${ }_{3}$ Meat Animals-Farm Production, Disposition, and Income, by States, 1957-1958, USDA, AMS, Crop Reporting Board, MTAN 1-1 (59) April 1959. 
TABLE 1. ESTIMATED CONSUMPTION, PRODUCTION, AND IMPORTATION OF MEAT IN NORTHEASTERN U. S., 1957*

\begin{tabular}{l|c|c|c|c|c}
\hline \hline \multirow{2}{*}{ Type of Meat } & $\begin{array}{c}\text { Consump- } \\
\text { tion }\end{array}$ & \multicolumn{2}{|c|}{ Production } & \multicolumn{2}{|c}{ Importation } \\
\cline { 2 - 5 } & $\begin{array}{c}\text { Lbs. } \\
\text { (Millions) }\end{array}$ & $\begin{array}{c}\text { Lbs. } \\
\text { (Millions) }\end{array}$ & $\begin{array}{c}\text { \% Of Con- } \\
\text { sumption }\end{array}$ & $\begin{array}{c}\text { Lbs. } \\
\text { (Millions) }\end{array}$ & $\begin{array}{c}\text { \% Of Con- } \\
\text { sumption }\end{array}$ \\
\hline Beef and Veal & 4,454 & 854 & 19.2 & 3,560 & 80.8 \\
Pork & 2,936 & 249 & 8.5 & 2,687 & 91.5 \\
Lamb and Mutton & 201 & 22 & 11.1 & 178 & 88.9 \\
\hline
\end{tabular}

* Estimating consumption, production, and importation of meats in the Northeast required population estimates, annual per capita consumption rates for the different meats, and total meat marketings by farmers in the region. Such information was compiled from: Population Estimates, July 1, 1957, Bureau of the Census, U. S. Department of Commerce, December 9, 1957, Series P-25, No. 168; Livestock and Meat Statistics, 1957, USDA, AMS, Statistical Bulletin Number 230, July 1958, pp. 283-289; Meat Animals-Farm Production, Disposition, and Income, by States, 1957-1958, USDA, AMS, Crop Reporting Board, MTAN 1-1 (59) April 1959.

The information in Livestock and Meat Statistics on farm meat marketings refers only to liveweight. Therefore, liveweights were converted to carcass weights by using a 13-year average dressing percentage for all cattle, calves, hogs, sheep and lambs slaughtered under federal inspection (see pp. 201-202 in Livestock and Meat Statistics).

Consumption figures were derived by multiplying the estimated population in the 12 Northeast states $(47,738,000)$ by the national rates of meat consumption per capita for 1957 ( 84.5 pounds of beef, 8.8 pounds of veal, 4.2 pounds of lamb and mutton, and 61.5 pounds of pork per capita).

farmers; a sum which represents something other than a minor by-product.

For farmers to realize the greatest return from their livestock, they need to be informed on such things as prices, markets, grades, etc. The procedures and practices followed by producers up to the time animals are sold are in no small way partial determinants of the amount of income received from marketing livestock.

\section{General Characteristics of Northeast Farmers}

\section{INCOME SOURCES AND TYPE FARMS}

Realizing that most Northeast farmers were engaged in dairying, the survey was designed to place major emphasis upon the marketing practices and procedures followed in purchasing replacement livestock and selling cull dairy animals and calves. Altogether, 1,314 producers were interviewed, ${ }^{4}$ and 812 or 62 per cent listed dairying as their principal source of income (Table 2). The second largest group of respondents (16 per cent) depended upon work-off-farm for their primary source of income. The remaining producers relied upon other farm enterprises for their principal source of income, but none of these accounted for more than 10 per cent of all respondents.

Since there were farmers in all classifications who bought, sold and raised livestock, though often in limited quantities, it was postulated that differences in marketing practices and procedures may be associated with type of farming. To insure that if such differences did exist they

4 The number of schedules for each state are: Connecticut, 17; Maine, 60; Maryland and Delaware, 82; Massachusetts, 34; New Hampshire, 22; New Jersey, 44; New York, 468; Pennsylvania, 376; Vermont, 73; West Virginia, 138. 


\section{TABLE. 2 PRINCIPAL SOURCE OF INCOME FOR A SAMPLE OF NORTHEASTERN UNITED STATES FARMERS}

\begin{tabular}{l|c|c}
\hline \multicolumn{1}{c|}{ Source } & No. of Respondents & Per Cent \\
\hline Dairying -arm & 812 & 62 \\
Work-Off-Farm & 207 & 16 \\
Livestock - & 105 & 8 \\
Poultry & 51 & 4 \\
Grain - & 41 & 3 \\
General Farming & 36 & 3 \\
Vegetables & 31 & 2 \\
Retirement Earnings* & 13 & 1 \\
Fruits - & 12 & 1 \\
Unknown - & 6 & $* *$ \\
\multicolumn{1}{c}{ Total } & 1314 & 100 \\
\hline
\end{tabular}

* Pensions, Social Security, Trust Funds, Interest on Investments, etc.

** Less than one-half of 1 per cent.

could be delineated, the data were stratified according to type of farming in most instances.

The classification for each respondent was ascertained by asking the individual what was his or her principal source of income for the preceding year. No attempt was made to determine the amount of income from each farm and non-farm source and the principal source of income as enumerated by the respondent is reported as the type of farming carried out by that individual. For example, respondents who stated that their principal source of income was from off-farm employment are classified under work-off-farm. Those listing dairying as their principal source of income are classified under dairy-type farmers, etc.

The interviewees were also asked what were their second and third most important sources of income. Since numerical measurements were not made of the contribution to total income from each source, the second and third principal sources of income were not used in defining type of farming. Most of the producers knew their second, but very few knew their third principal source of income. Tables 3 and 4 indicate that in addition to dairy and livestock producers many Northeastern farmers received part of their income from livestock or dairying.

Due to variations in plant facilities, production practices, and marketing procedures existing among farmers, one commonly speaks about an average or modal type farmer for each farm type. In the following discussion of physical inventory, the typical farmer for each category, based on an average or mode, is the reference point. 

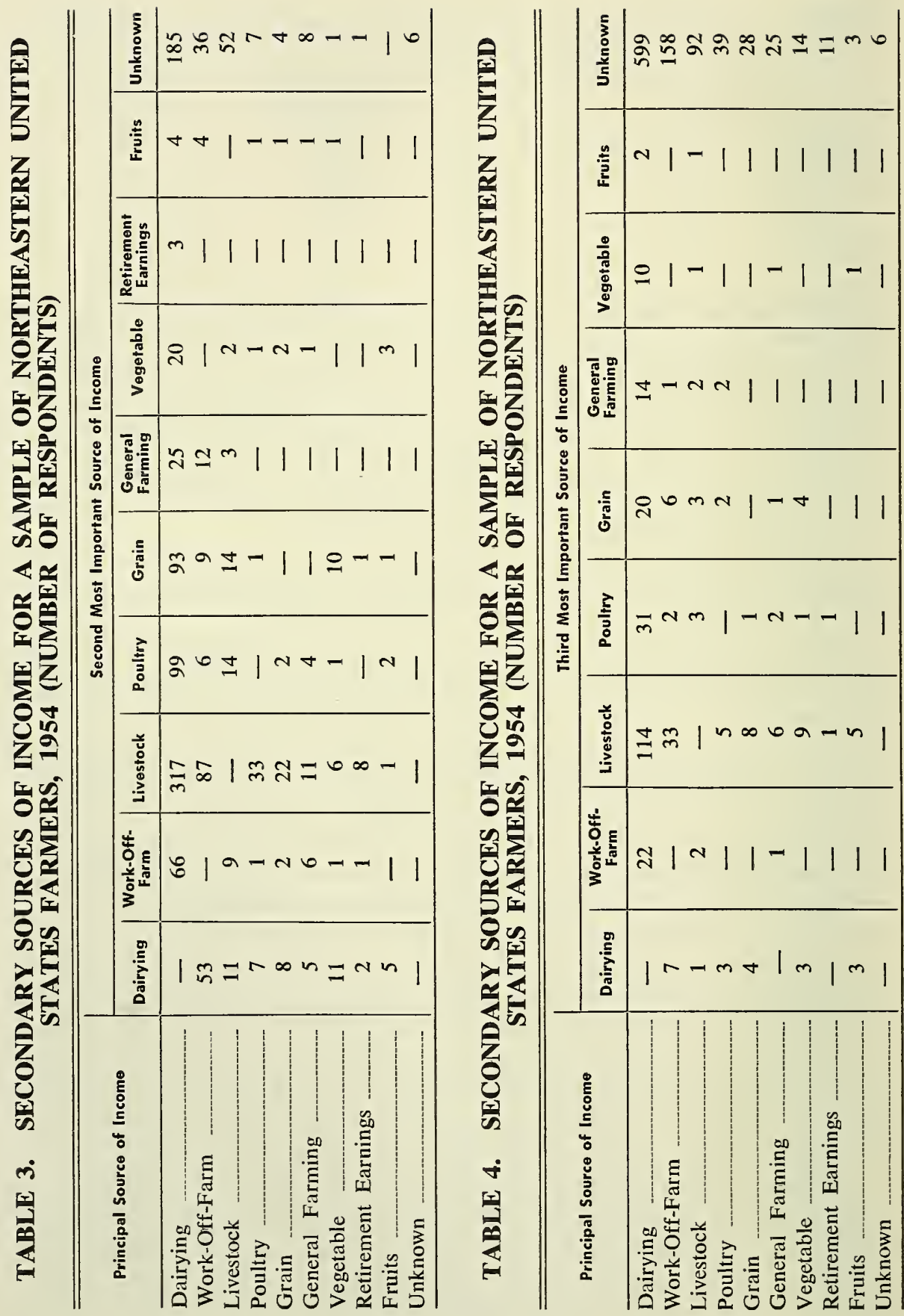


\section{ACRES OPERATED}

The data in Table 5 indicate that dairy and livestock producers operated the largest number of acres, and retired workers operated the smallest number. In general, persons not dependent upon farming for their principal source of income operated considerably fewer acres than those producers who earned their livelihood primarily from farming. ${ }^{5}$

\section{ROAD TYPE}

Forty-nine per cent of all respondents lived near a hard-top road, one-fourth near a dirt road, and one-fifth near a gravel road (Table 6). Among the farm types a higher proportion of the vegetable producers ( 74 per cent) resided near a hard-surfaced road than any other farm type; dairy farmers ranked second (52 per cent). Grain farmers ranked lowest in the proportion living near a hard-top road and the highest living near a dirt road. A fairly high proportion of the livestock farmers and retired workers lived near a dirt road.

\section{TRUCK OWNERSHIP}

Approximately three-fifths (61 per cent) of all respondents owned a truck (Table 7). Most of the producers had only one truck, but 5 per cent stated they owned two or more trucks. Among the farm types, vegetable and fruit farmers had the highest percentage ownership ( 87 and 88 per cent, respectively), and retired workers and respondents working off farm had the least percentage ownership (46 and 48 per cent, respectively). ${ }^{\circ}$

The most popular size truck among all respondents was the $1 / 2$-ton pick-up. Ranking second in ownership, and very close to the pick-up

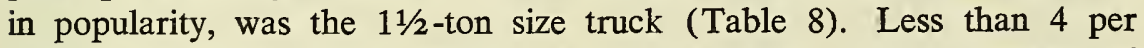
cent of all trucks owned weighed 4 tons or more. Almost one-fifth of the producers who stated they owned a truck did not know the truck size. Among the farm types a higher proportion of the grain, vegetable, and fruit farmers had $1 \frac{1 / 2}{2}$-ton trucks, while poultry, fruit, general farming, and work-off-farm had the highest proportions of $1 / 2$-ton trucks.

About three-fifths of all respondents owning trucks used them in their livestock operations (Table 9). A greater proportion of livestock farmers used their trucks for hauling livestock than other farm types.

\footnotetext{
5 An analysis of variance test was performed to see if the differences in acreage operated by type of farming were significant. At the 5 per cent level, no difference was noted between the number of acres operated by dairy, livestock, and vegetable producers. Retired workers and poultry farmers each operated significantly fewer acres than did seven of the other eight farm types. The acreage data for unknown type of farming was omitted from the analysis due to the small number of respondents.

$6 \mathrm{~A}$ chi square test at the 5 and 1 per cent levels of significance indicated that ownership of trucks and type of farming were not independent of each other. In other words, there was a relationship between the type of farming and the ownership of trucks.
} 


\begin{tabular}{|c|c|c|c|c|c|c|}
\hline 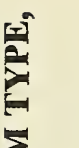 & & $\bar{\alpha} \sum_{\Sigma}^{\infty}$ & $\dot{i}$ & 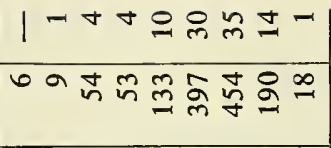 & $\begin{array}{l}\frac{8}{0} \\
\frac{ \pm}{m} \\
=\end{array}$ & $\stackrel{\infty}{\simeq}$ \\
\hline & & $\xi$ & ¿ & $|1 \equiv| m \equiv m \mid 1$ & 8 & \\
\hline & & 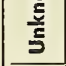 & $\dot{0}$ & $|1-| c-n \mid 1$ & 6 & 웅 \\
\hline & & 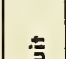 & ¿ & ||||$m m m||$ & 8 & \\
\hline & & L & $\dot{0}$ & $1111+\forall+11$ & $\stackrel{\sim}{\sim}$ & $\infty$ \\
\hline $2 \stackrel{2}{2}$ & & శ్ & ১ & $|\infty m \vec{n} m \cong| \mid 1$ & 8 & \\
\hline Eñ & & 㐔 & $\dot{0}$ & $|\rightarrow m \tan |||$ & $m$ & तิ \\
\hline$\sum_{i}^{2}$ & & $\frac{1}{2}$ & $\circ^{0}$ & 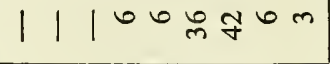 & @ & \\
\hline 近造 & & g. & $\dot{0}$ & $|1| n n=m a n$ & $\bar{m}$ & $\stackrel{\text { I }}{=}$ \\
\hline$=\sum_{2}$ & 竞 & "ू. & $\curvearrowright 0$ & $m|m| \underset{N}{\infty} \stackrel{\infty}{\sim}=1$ & ○ & \\
\hline 둥 & 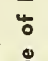 & Oٓ & $\dot{3}$ & 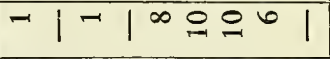 & $\ddot{m}$ & $\equiv$ \\
\hline 뜰ㄹ & $\stackrel{2}{2}$ & 咆 & ஃ & 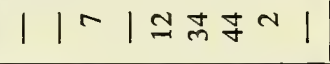 & 8 & \\
\hline$\theta$ & & ○े & $\dot{0}$ & ||$^{m} \mid n \pm \infty-1$ & $F$ & $\hat{a}$ \\
\hline$\psi_{2}^{2}$ & & 主 & ஃ & | 10 ำกำก & $\stackrel{8}{8}$ & \\
\hline 뜰ㄹㄹㄹㄹ & & $\stackrel{0}{0}$ & $\dot{0}$ & ||$^{n}=m m \infty \mid$ & $\bar{n}$ & $\vec{b}$ \\
\hline$\sum_{5}^{3}$ & & $\stackrel{\breve{~}}{\frac{\breve{g}}{\omega}}$ & ஃ & $\mid 1+\forall m$ กิ & 8 & \\
\hline ZZ & & $\stackrel{\circ}{\stackrel{0}{3}}$ & $\dot{0}$ & 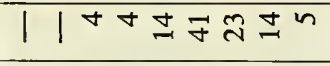 & $\cong$ & $\stackrel{0}{2}$ \\
\hline 룽 & & 它E & $\curvearrowright 0$ & $\because m \underline{\sim}$ & $\stackrel{8}{\circ}$ & \\
\hline 돌 뚤 & & $3^{5}$ & $\dot{0}$ & ーヘ & हิ & 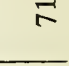 \\
\hline 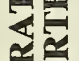 & & 류 & $\stackrel{0}{\circ}$ & 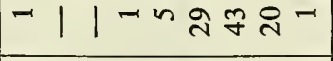 & 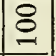 & \\
\hline $\begin{array}{l}-\frac{2}{2} \\
\frac{2}{0}\end{array}$ & & & $\dot{0}$ & 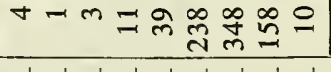 & $\frac{N}{\infty}$ & \pm \\
\hline 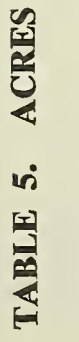 & & 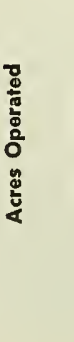 & & 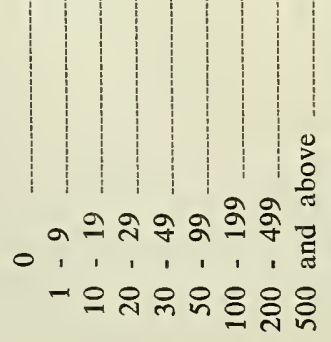 & & 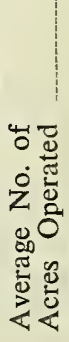 \\
\hline
\end{tabular}



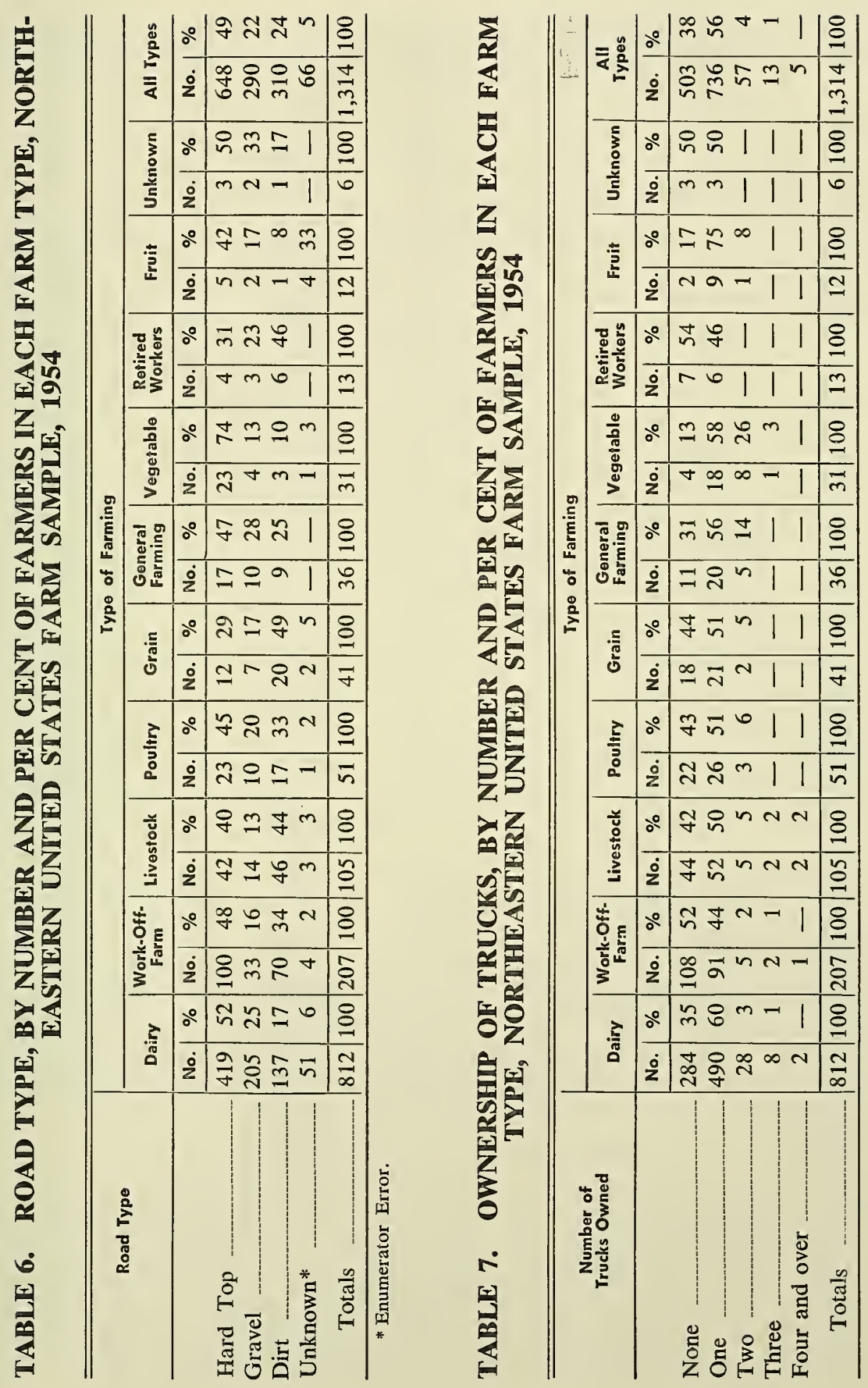


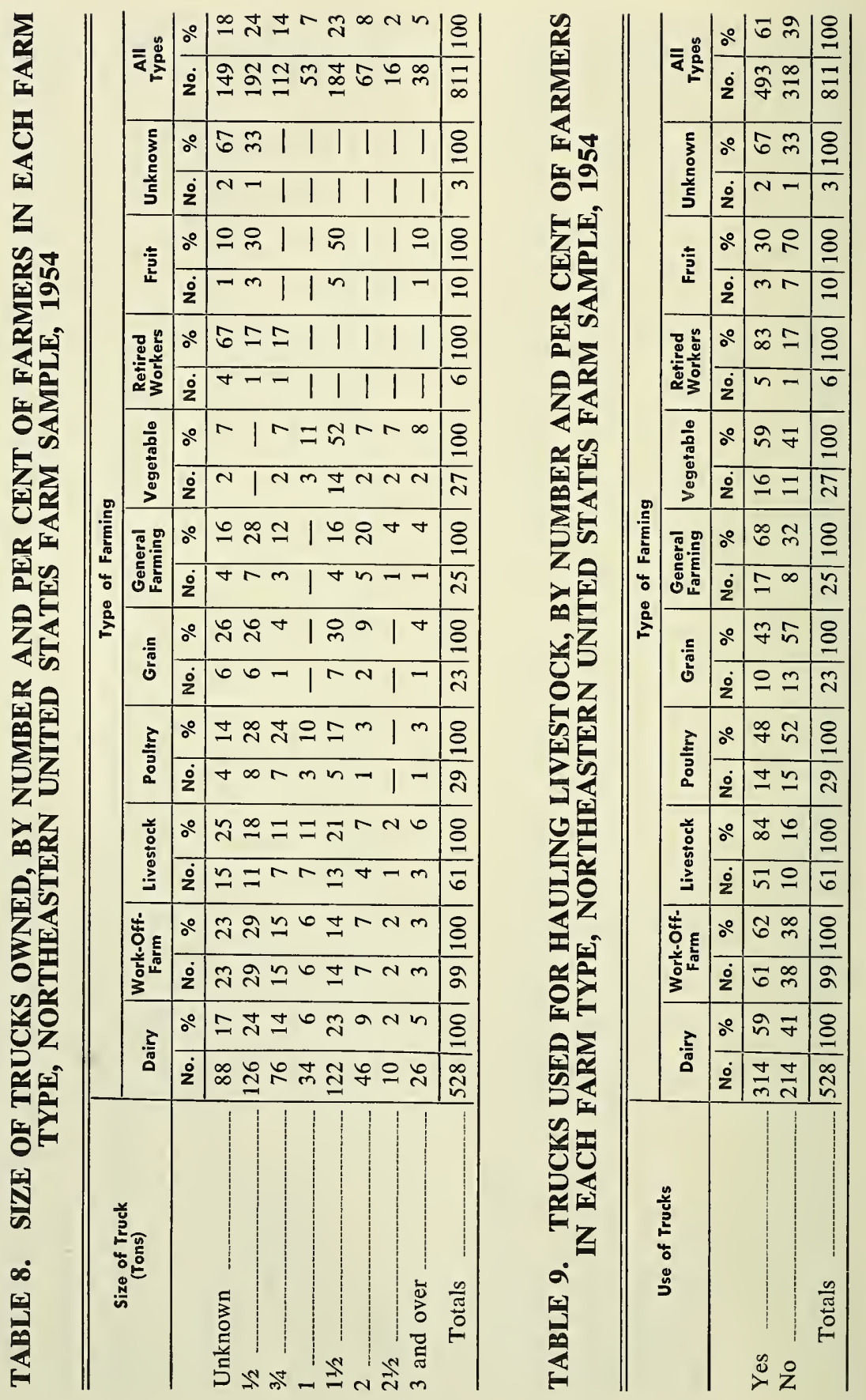


In general, the use of trucks in hauling livestock tends to be greatest where livestock contributes substantially to farm income.

\section{NUMBER AND KIND OF LIVESTOCK ON FARMS}

The survey obtained an inventory of animals on farms January 1, 1954. Data in Table 10 show the average numbers of livestock on the different types of farms. With the exception of livestock producers, most farmers in each farm type had very few hogs, beef-type cattle, sheep, and lambs on their farms January 1, 1954 (Tables 11 through 14). In addition to dairy farmers a large number of the respondents in each farm type had four or more dairy animals on the farm.

The data in Table 11 show the relatively large size of dairy herds, with the typical herd numbering between 31-50 animals. Less than a fourth of the dairy farmers had herds of 20 or fewer animals, and only 12 per cent had less than 15 animals. The data in Tables 12 through 14 also point out some exceptionally large dairy herds among types of farming other than dairying. Two vegetable producers had over a hundred dairy animals and yet vegetables, not dairying, was their principal source of income. A number of persons who depended upon work-off-farms for their principal source of income also owned rather sizeable numbers of dairy animals. Overwhelmingly, the practices and procedures used in marketing livestock in the Northeast are concerned with marketing dairy cattle and calves. As most dairy farmers consider this a by-product of milk production, efforts to improve the efficiency of marketing these animals have been rather meager.

\section{MEMBERSHIP IN HERD IMPROVEMENT ASSOCIATIONS}

Approximately 12 per cent of the respondents belonged to some type of herd improvement association (Table 15). Most of the producers belonging to an association were dairy farmers who were members of DHIA. Even among the dairy producers less than 20 per cent of the farmers belonged to a herd improvement association.

\section{DISTANCE TO LIVESTOCK DEALERS AND/OR AUCTIONS}

The importance of livestock dealers as a marketing agency varies among the Northeastern states, with their influence generally increasing as one moves northeast from West Virginia, Maryland, and Pennsylvania into New York, Vermont, and Maine. These dealers are widely scattered and, for the most part, their operations are on a part-time basis. Many are farmers who entered the dealer business to supplement their farm income. 


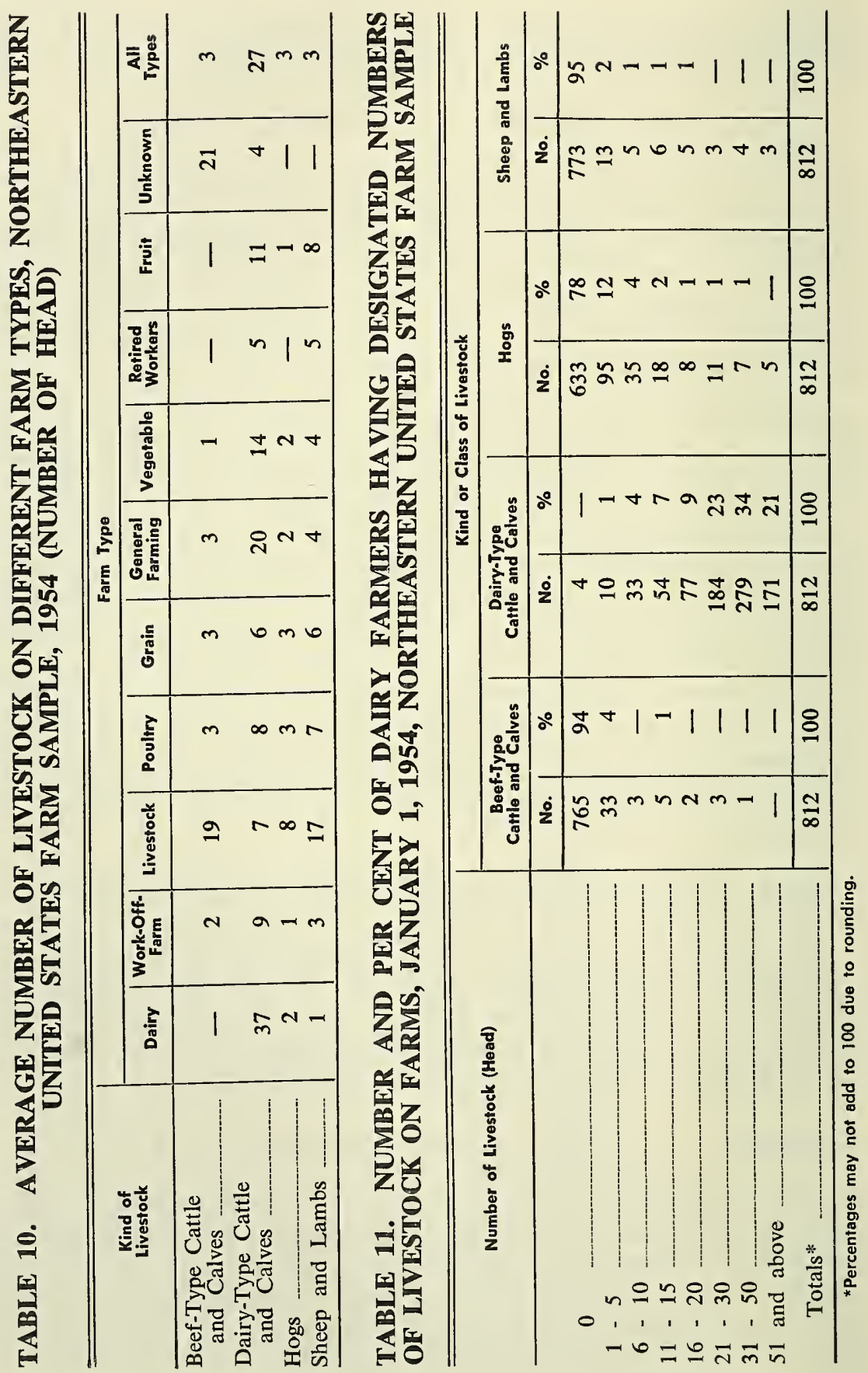


TABLE 12. NUMBER AND PER CENT OF WORK-OFF-FARM FARMERS HAVING DESIGNATED NUMBERS OF LIVESTOCK ON FARMS, JANUARY 1, 1954, NORTHEASTERN UNITED STATES FARM SAMPLE

\begin{tabular}{|c|c|c|c|c|c|c|c|c|c|}
\hline \multirow{2}{*}{\multicolumn{2}{|c|}{$\begin{array}{l}\text { Number of } \\
\text { Livestock (Head) }\end{array}$}} & \multicolumn{8}{|c|}{ Kind or Class of Livestock } \\
\hline & & \multicolumn{2}{|c|}{$\begin{array}{c}\text { Beef-Type } \\
\text { Cattle and Calves }\end{array}$} & \multicolumn{2}{|c|}{$\begin{array}{l}\text { Deiry-Type } \\
\text { Cattle and Calves }\end{array}$} & \multicolumn{2}{|c|}{ Hogs } & \multicolumn{2}{|c|}{ Shoep and lambs } \\
\hline & & No. & $\%$ & No. & $\%$ & No. & $\%$ & No. & $\%$ \\
\hline & 0 & 161 & 78 & 43 & 21 & 160 & 77 & 177 & 86 \\
\hline 1 & -5 & 15 & 7 & 79 & 38 & 39 & 19 & 5 & 2 \\
\hline 6 & -10 & 14 & 7 & 38 & 18 & 5 & 2 & 7 & 3 \\
\hline 11 & $-15 \ldots$ & 7 & 3 & 11 & 5 & - & - & 2 & 1 \\
\hline 16 & -20 & 2 & 1 & 9 & 4 & 2 & 1 & 2 & 1 \\
\hline 21 & -30 & 6 & 3 & 13 & 6 & 1 & - & 8 & 4 \\
\hline 31 & -50 & 2 & 1 & 9 & 4 & - & - & 4 & 2 \\
\hline 51 & and above & - & - & 5 & 2 & - & - & 2 & 1 \\
\hline & Totals* & 207 & 100 & 207 & 100 & 207 & 100 & 207 & 100 \\
\hline
\end{tabular}

*Percentages may not add to 100 due to rounding.

TABLE 13. NUMBER AND PER CENT OF LIVESTOCK FARMERS HAVING DESIGNATED NUMBERS OF LIVESTOCK ON FARMS, JANUARY 1, 1954, NORTHEASTERN UNITED STATES FARM SAMPLE

\begin{tabular}{|c|c|c|c|c|c|c|c|c|c|}
\hline \multirow{2}{*}{\multicolumn{2}{|c|}{$\begin{array}{l}\text { Number of } \\
\text { Livestock (Head) }\end{array}$}} & \multicolumn{8}{|c|}{ Kind or Class of Livestock } \\
\hline & & \multicolumn{2}{|c|}{$\begin{array}{l}\text { Beef-Type } \\
\text { Cattle and Calves }\end{array}$} & \multicolumn{2}{|c|}{$\begin{array}{c}\text { Dairy-Type } \\
\text { Cottle and Calves }\end{array}$} & \multicolumn{2}{|c|}{ Hogs } & \multicolumn{2}{|c|}{ Sheop and Lambs } \\
\hline & & No. & $\%$ & No. & $\%$ & No. & $\%$ & No. & $\%$ \\
\hline & 0 & 46 & 44 & 39 & 37 & 53 & 50 & 73 & 70 \\
\hline & - 5 & 11 & 10 & 32 & 30 & 22 & 21 & - & - \\
\hline 6 & -10 & 11 & 10 & 15 & 14 & 11 & 10 & 2 & 2 \\
\hline 11 & 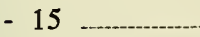 & 6 & 6 & 4 & 4 & 5 & 5 & 5 & 5 \\
\hline 16 & -20 & 6 & 6 & 5 & 5 & 3 & 3 & 1 & 1 \\
\hline 21 & -30 & 6 & 6 & 3 & 3 & 5 & 5 & 10 & 10 \\
\hline 31 & -50 & 9 & 9 & 6 & 6 & 2 & 2 & 6 & 6 \\
\hline 51 & and above & 10 & 10 & 1 & 1 & 4 & 4 & 8 & 8 \\
\hline & Totals* & 105 & 100 & 105 & 100 & 105 & 100 & 105 & 100 \\
\hline
\end{tabular}

*Percentages may not add to 100 due to rounding.

About one-third of the producers interviewed had no idea how far it was to the dealer nearest their farm (Table 16). About three-fifths of all producers lived within 30 miles of the nearest dealer and one-tenth lived more than 30 miles from the nearest dealer.

Approximately nine-tenths of all the producers knew how far it was from their farm to the nearest auction, whereas only two-thirds knew 
TABLE 14. NUMBER AND PER CENT OF POULTRY, GRAIN, VEGETABLE, RETIRED, FRUIT, UNKNOWN AND GENERAL FARMING TYPE FARMERS HAVING DESIGNATED NUMBERS OF LIVESTOCK ON FARMS JANUARY 1, 1954, NORTHEASTERN UNITED STATES FARM SAMPLE*

\begin{tabular}{|c|c|c|c|c|c|c|c|c|c|}
\hline \multirow{2}{*}{\multicolumn{2}{|c|}{$\begin{array}{c}\text { Number of } \\
\text { Livestock (Head) }\end{array}$}} & \multicolumn{8}{|c|}{ Kind or Class of Livestock } \\
\hline & & \multicolumn{2}{|c|}{$\begin{array}{c}\text { Beef-Type } \\
\text { Cattle and Calves }\end{array}$} & \multicolumn{2}{|c|}{$\begin{array}{c}\text { Dairy-Type } \\
\text { Cattle and Calves }\end{array}$} & \multicolumn{2}{|c|}{ Hogs } & \multicolumn{2}{|c|}{ Sheep and Lambs } \\
\hline & & No. & $\%$ & No. & $\%$ & No. & $\%$ & No. & $\%$ \\
\hline & 0 & 151 & 79 & 35 & 18 & 129 & 68 & 160 & 84 \\
\hline & -5 & 16 & 8 & 77 & 41 & 37 & 19 & 2 & 1 \\
\hline & -10 & 11 & 6 & 22 & 12 & 8 & 4 & 3 & 2 \\
\hline 11 & -15 & 3 & 2 & 18 & 9 & 6 & 3 & 1 & 1 \\
\hline 16 & $-20 \ldots$ & 4 & 2 & 13 & 7 & 8 & 4 & 5 & 3 \\
\hline 21 & -30 & - & - & 12 & 6 & 1 & 1 & 5 & 3 \\
\hline 31 & $-50 \ldots$ & 3 & 2 & 7 & 4 & 1 & 1 & 9 & 5 \\
\hline 51 & and above ... & 2 & 1 & 6 & 3 & - & - & 5 & 3 \\
\hline & Totals $\dagger$ & 190 & 100 & 190 & 100 & 190 & 100 & 190 & 100 \\
\hline
\end{tabular}

* Since the number of farmers in each of these farm types was relatively small the data were combined.

tPercentages may not add to 100 due to rounding.

how far it was to the nearest livestock dealer. About 63 per cent of all farmers lived within 30 miles of the nearest auction and 84 per cent lived within 50 miles of the nearest auction (Table 17).

\section{Livestock Sales}

Very few Northeast producers raise livestock primarily for sale as meat animals. Instead, the large majority sell livestock simply because they are by-products of their dairy enterprises. In some cases farmers raise and sell meat animals to supplement their primary source of income. The relatively small number of livestock sold by all producers, in addition to the small numbers sold by most individual farmers in each farm type, creates problems of concentration, adequate and timely marketing information, effective competition, and the maintenance of a continuous supply of livestock to support markets, prices, and marketing channels. In addition to the problems associated with relatively small numbers of livestock in scattered areas, a majority of the animals marketed in the Northeast do not cut out high quality meats. These problems of supply and meat quality are overcome by massive inter-regional purchases of livestock and meat by Northeastern livestock slaughterers.

\section{TYPE AND NUMBER SOLD}

The survey results indicated that during 1954 producers sold about three times the number of dairy-type cattle as of beef-type cattle (Table 


\begin{tabular}{|c|c|c|c|c|}
\hline & & $\circ 1$ & $\simeq \infty^{m}$ & 8 \\
\hline 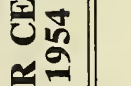 & $\bar{\alpha}$ & $\stackrel{0}{2}$ & 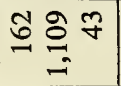 & $\vec{m}$ \\
\hline & $\bar{z}$ & $\therefore$ & 181 & 8 \\
\hline $\bar{\varepsilon}$ & 咅 & i & 101 & 6 \\
\hline & & $\circ$ & $1 \cong 2$ & 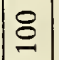 \\
\hline$\sum$ & 芯 & $\begin{array}{l}0 \\
\end{array}$ & $10 \mathrm{~m}$ & $\simeq$ \\
\hline & 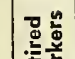 & $\therefore$ & $\infty \underset{\infty}{+\infty}$ & 8 \\
\hline & 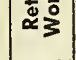 & io & $-=-$ & $m$ \\
\hline & $\frac{9}{0}$ & $\therefore$ & $m \sigma^{\circ}$ & 8 \\
\hline 6 & $\stackrel{\Phi}{ \pm}$ & $\dot{0}$ & $-\infty$ & $\bar{m}$ \\
\hline 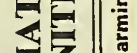 & 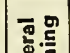 & $\therefore$ & $\infty$ a $m$ & 8 \\
\hline$\frac{}{0}$ & 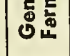 & $\dot{0}$ & $m$ Nల - & m \\
\hline 2 & & $\circ$ & Nan & 8 \\
\hline 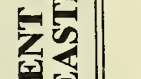 & 50 & $\frac{\dot{0}}{2}$ & $-\infty$ & $\bar{F}$ \\
\hline 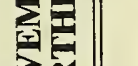 & 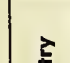 & $\circ$ & $\infty \infty_{\infty}^{\infty}$ & 8 \\
\hline 8 & ב⿳亠口冋े & $\dot{0}$ & $\nabla \forall m$ & $\bar{n}$ \\
\hline & 苂 & $\circ$ & - & 8 \\
\hline & 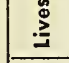 & $\dot{0}$ & rá & 气 \\
\hline & 峞 & 2 & $-\infty+$ & 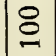 \\
\hline & $\sum^{3}$ & i & $\pm \underset{\infty}{\infty}$ & i) \\
\hline & . & $\circ$ & $=\bar{\infty}^{m}$ & 8 \\
\hline 4 & อ & i & $\overline{2}$ ह్రి & $\frac{\pi}{\infty}$ \\
\hline
\end{tabular}

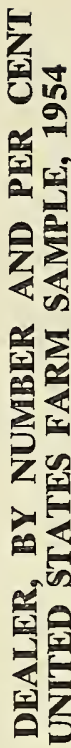

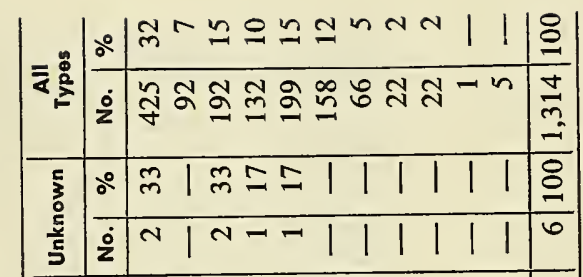

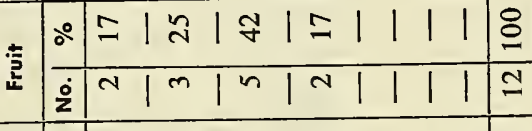

일

高

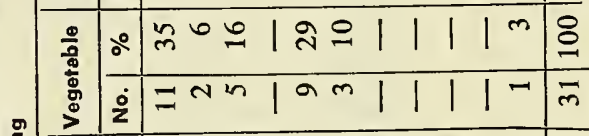

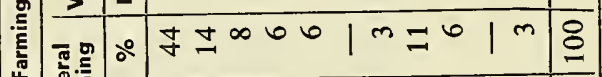

రิ

告灵

8

보의

단

2 덜

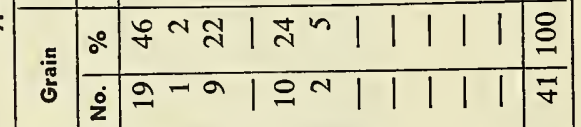

등

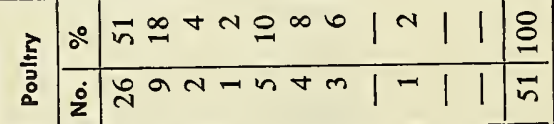

즌

द्व

둘

될

룰

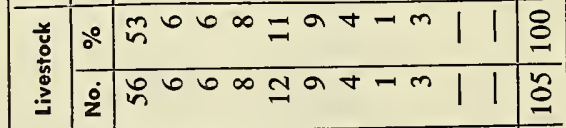

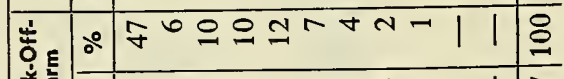

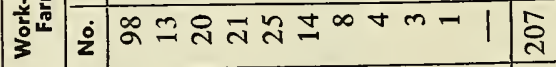

인

동

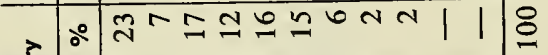

寉

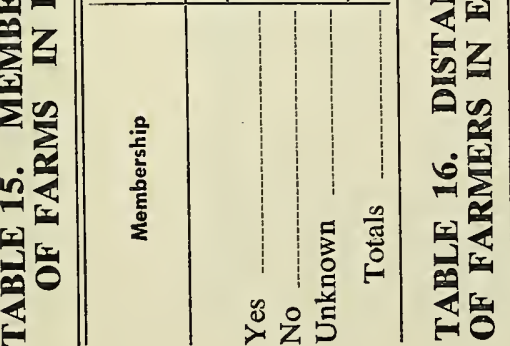

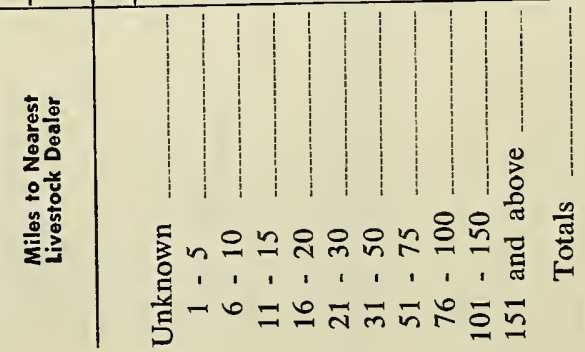




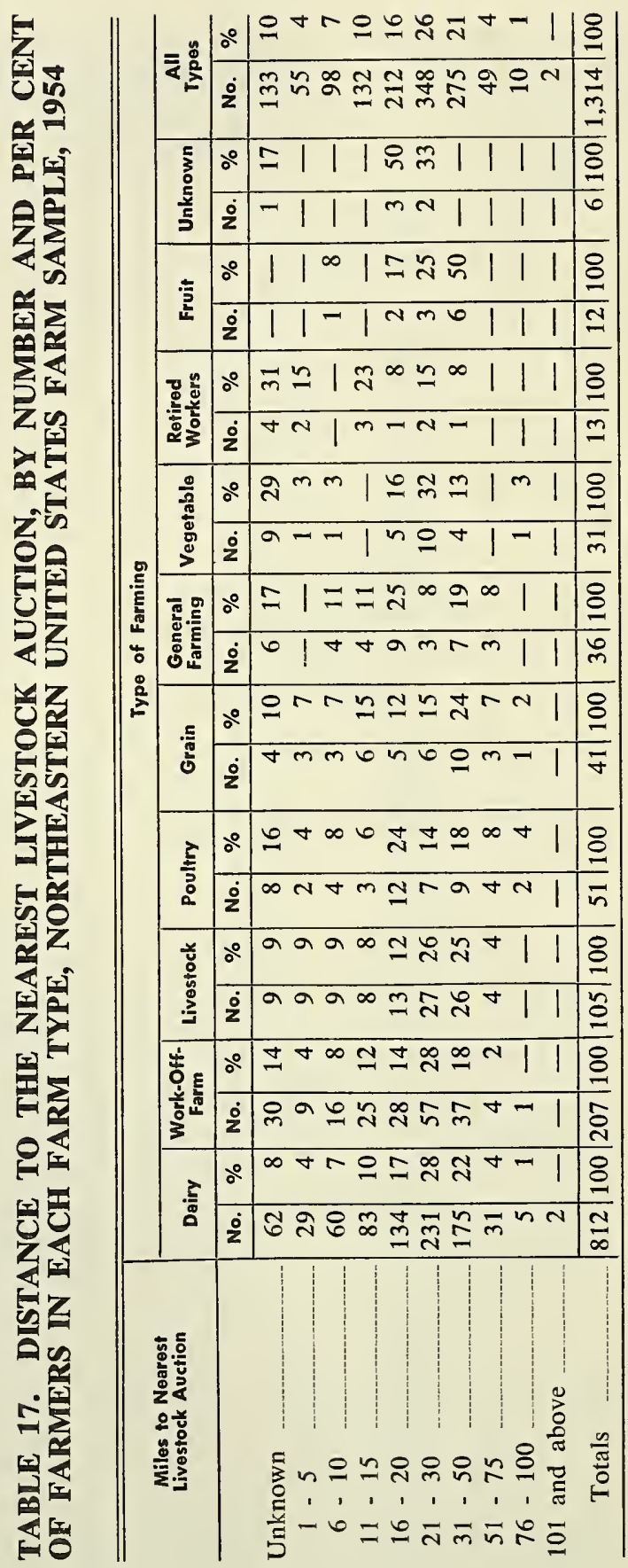




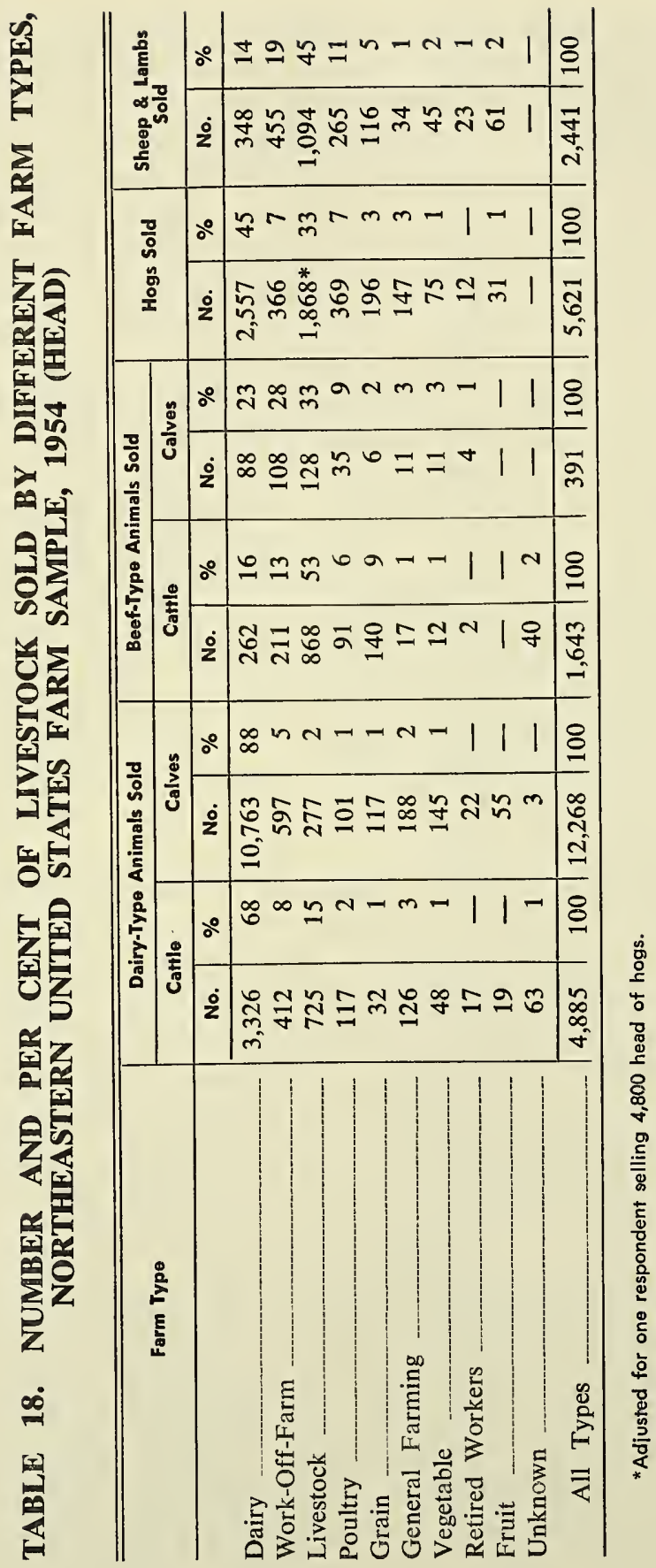


18). During the same period, the number of dairy-type calves sold was approximately 30 times greater than the number of beef-type calves sold. The number of hogs and sheep sold was quite low and for all practical purposes can be considered insignificant.

Livestock sales by livestock and unknown type producers averaged 21.2 and 17.3 animal units, respectively. Excluding livestock farmers and those few farmers who did not give their principal source of income, the average number of livestock animal units sold by producers was slightly under 7 (Table 19). For all producers the average number of animal units sold was approximately 8 .

By type of farming, dairying and livestock accounted for 83 per cent of the dairy-type cattle sold, 69 per cent of the beef-type cattle, 90 per cent of the dairy-type calves, and 56 per cent of the beef-type calves (Table 18). Dairy producers accounted for 68 per cent of the dairy-type cattle, 16 per cent of the beef-type cattle, 88 per cent of the dairy-type calves, and 23 per cent of the beef-type calves. Those farmers who depended upon work-off-farm for their principal source of income ranked third in the numbers of livestock sold. These part-time farmers marketed 8 per cent of the dairy-type cattle sold, 13 per cent of the beeftype cattle, 5 per cent of the dairy-type calves, and 28 per cent of the beeftype calves. The sales for all other farm types were very small with no farm type accounting for more than 11 per cent of each kind of class of livestock sold.

The number of hogs and sheep sold was so small for all types of farming except livestock and dairying that such sales are not considered in much detail. Together, livestock and dairy farmers sold 78 per cent of all hogs and 59 per cent of all sheep (Table 18). Livestock farmers alone sold 33 per cent of all hogs and 45 per cent of all sheep. An analysis of variance test using all comparisons among means indicated, at the 5 per cent level of significance, that dairy farmers marketed significantly more animal units than all other farm types. Livestock farmers and producers who work-off-farm each sold a significantly larger number of animal units than all other farm types except dairy.

\section{SALES OUTLETS}

Auctions represented the single most important outlet for livestock sold by Northeastern farmers (Table 20). About half of all cattle, calves, sheep, and lambs were marketed through this outlet. Dealers were the second most important outlet with approximately one-fourth of all cattle and calves sold to these buyers. Together, auctions and dealers accounted for 71 per cent of all cattle sold, 79 per cent of the calves, 38 per cent of the hogs, and 62 per cent of the sheep and lambs. The third, fourth, and fifth ranking outlets were, respectively, terminals, meat packers, 


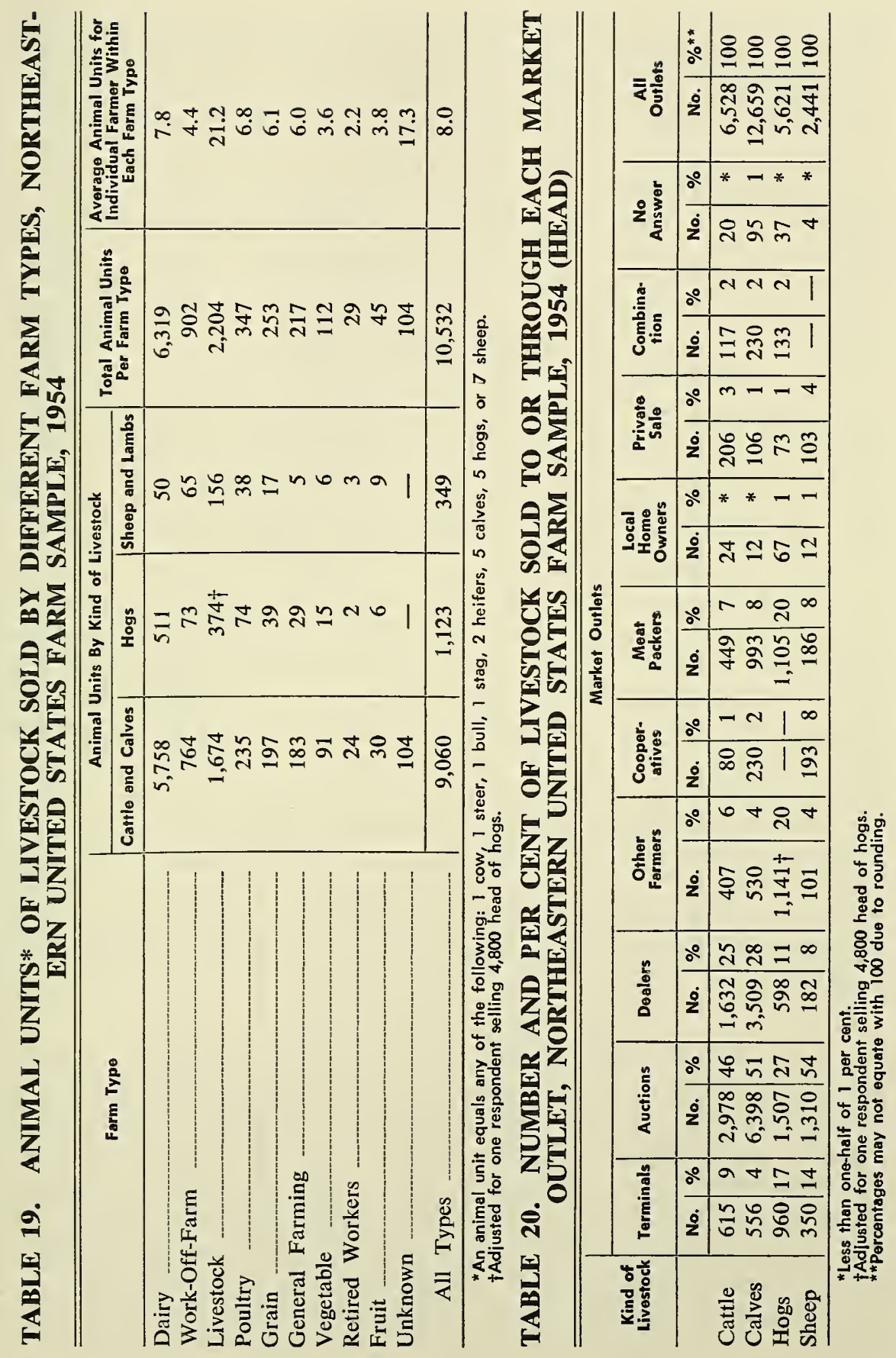


and other farmers. About equal proportions of livestock animal units were sold through those outlets (Table 21). Sales through each of the remaining outlets were generally responsible for less than 15 per cent of each kind of meat animal sold. Hog sales were rather evenly divided among auctions, meat packers, other farmers, and terminals.

An analysis of variance test indicated at the 5 and 1 per cent levels of significance that there were significant differences in the numbers of livestock (animal units) marketed through the several outlets. A more refined test of all comparisons among markets at the 5 per cent level of significance indicated that the number of animal units marketed through auctions were significantly larger than the numbers marketed through all outlets except dealers. The differences in numbers marketed through auctions and dealers were not significant. Sales to livestock dealers were significantly larger than those to "private buyers," but no different from all other outlets. Excluding the significant difference between dealers and "private buyers" and between auctions and all outlets except dealers, there were no other significant differences in animal units marketed through the several agencies.

Dairy producers, retired workers, off-farm workers, and vegetable farmers sold a large majority of their livestock through auctions and to livestock dealers (Tables 21 and 22). More than two-thirds of all animal units sold by each of these farm types were marketed through those two outlets. Livestock, grain, fruit, and general farming types sold more than half of their livestock through auctions or to dealers. Poultry farmers had no clear-cut marketing patterns, but tended to market more of their livestock through auctions and to meat packers. Of the total animal units marketed, 30 per cent were sold through auctions, 25 per cent to meat packers, 20 per cent through terminals, 13 per cent to other farmers, and 11 per cent to dealers (Tables 21 and 22). Farmers not knowing their principal source of income sold most of their livestock to dealers.

\section{LIVESTOCK DELIVERY}

Since most Northeastern producers live within 30 miles of the nearest auction or 25 miles of the nearest livestock dealer, transportation of livestock to market does not generally present a problem. Animals purchased from dealers are usually delivered to the farm by the dealers and those purchased at auctions or from other farmers are transported by the farmers buying the livestock. Many of the producers who do not own trucks make arrangements to have their livestock hauled by neighbors; others contract truckers to transport animals bought and sold. A number of these hired truckers are livestock dealers who transport livestock as a supplementary source to their dealer income. There are some 


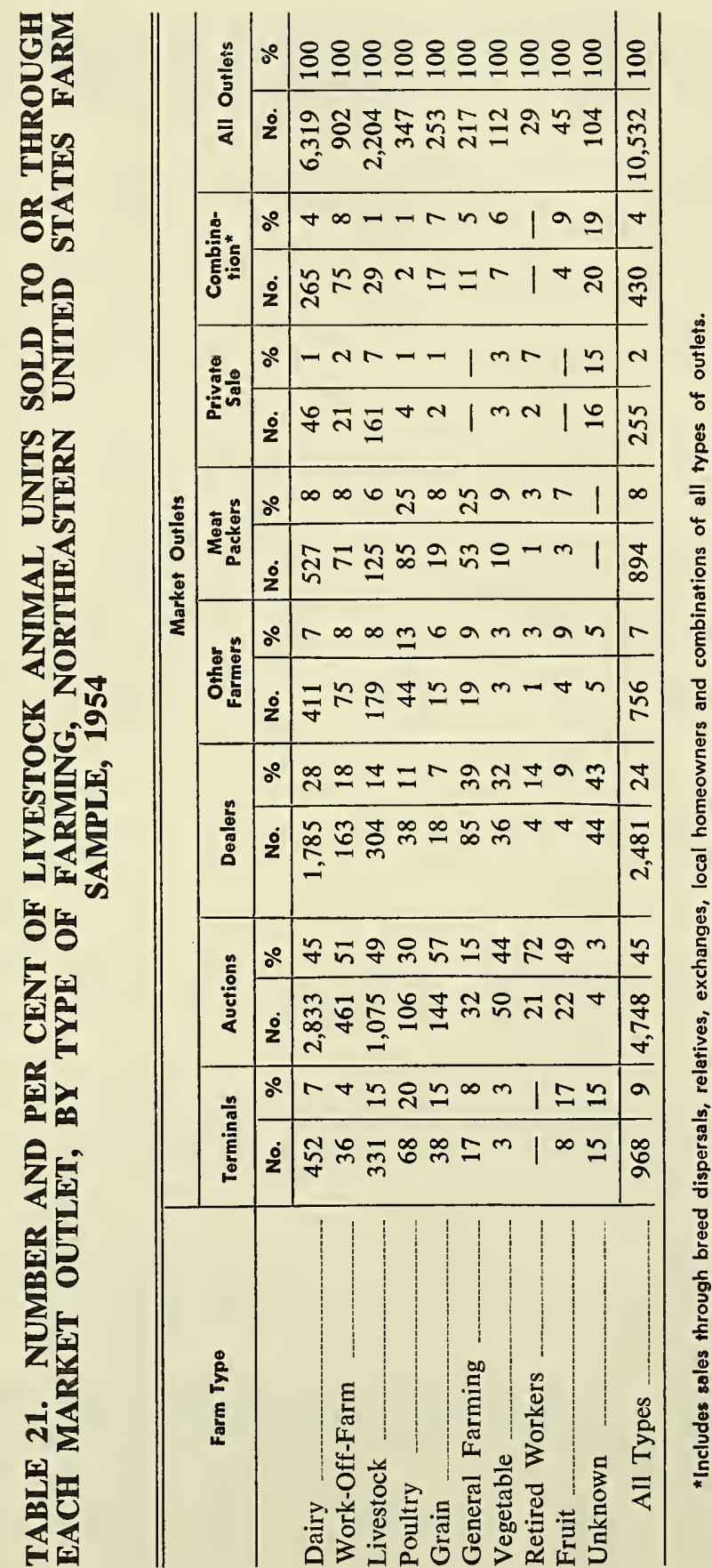




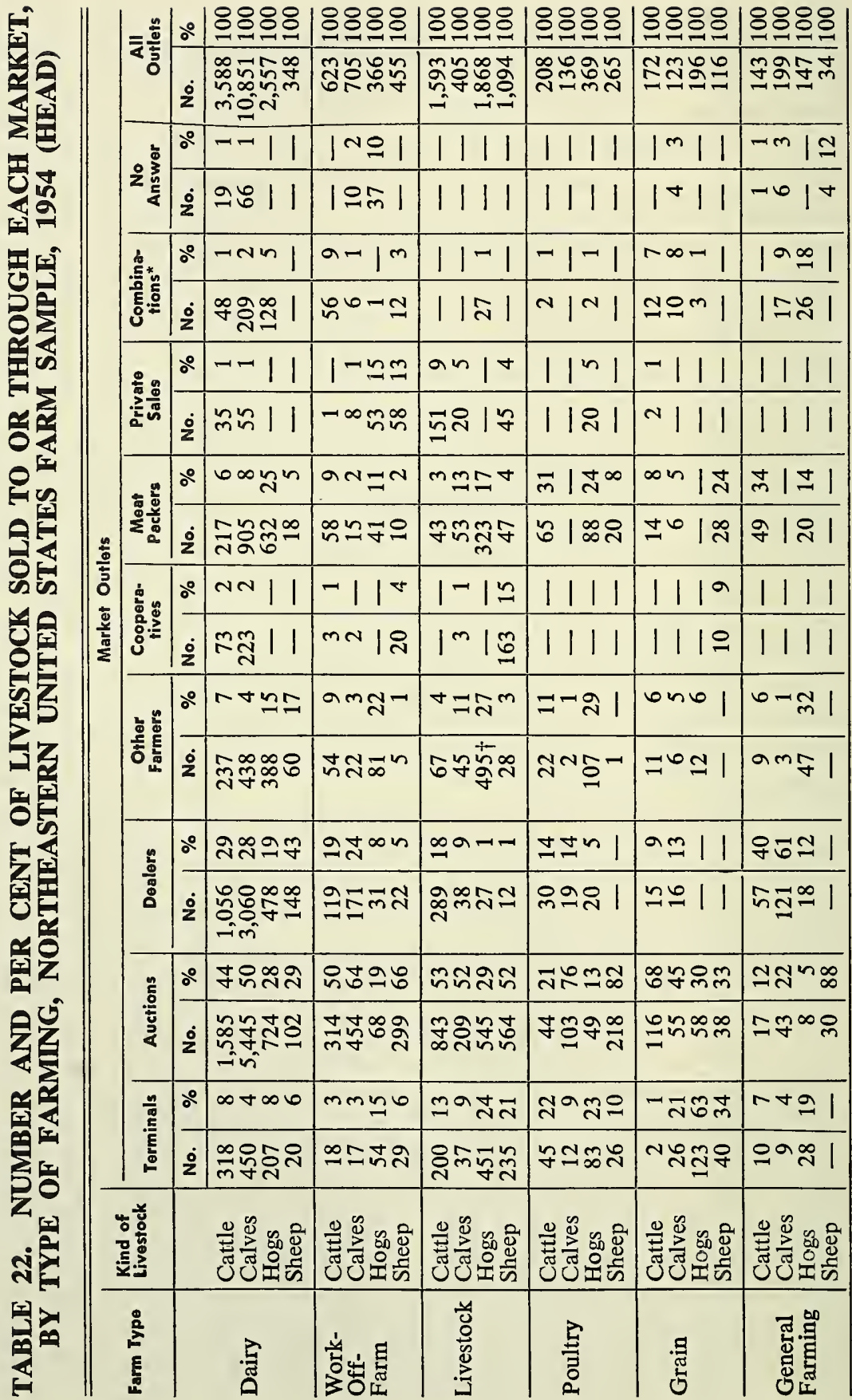




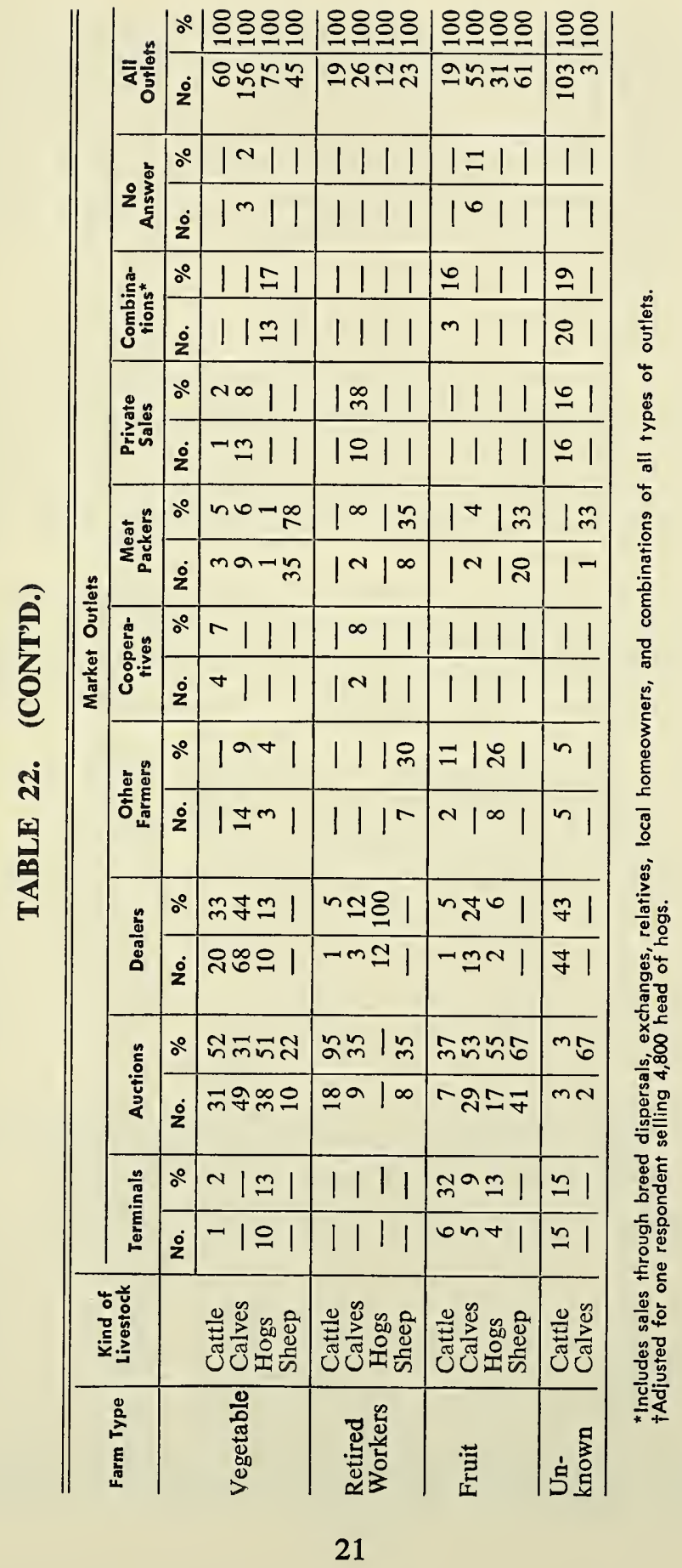


producers who incur no direct transportation costs by selling all of their livestock at the farm and raising all of their replacement stock.

The data in Table 23 show that Northeast producers delivered about two-thirds of all animals sold in 1954. At the same time producers bore the costs of transporting approximately 60 per cent of all the livestock they purchased (Table 24). Thus, farmers in the region paid directly some 60 to 65 per cent of all transportation costs for delivering livestock bought and sold.

\section{LIVESTOCK MARKET NEWS INFORMATION}

Producers who are well informed about conditions existing in the market place may be in a much better bargaining position than those who are not so well informed. Like other livestock buyers, farmers need adequate and timely information to get the best returns from buying and selling, or at least to know what the best possible returns could have been.

The data in Table 25 indicate that a large majority of Northeast producers are in a position to be informed. During 1954 approximately two-thirds of all farmers surveyed received information regularly on livestock market prices. Of those producers receiving information, 70 per

\section{TABLE 23. TRANSPORTING LIVESTOCK SOLD BY NORTH- EASTERN FARM PRODUCERS, NORTHEASTERN UNITED STATES FARM SAMPLE, 1954 (HEAD)}

\begin{tabular}{l|r|r|r|r|r|r|r|r|}
\hline \hline \multicolumn{1}{c|}{ Kind of Livestock } & Buyer Delivered & \multicolumn{2}{c|}{ Seller Delivered* } & \multicolumn{2}{|c|}{ No Answer } & \multicolumn{2}{|c|}{ Total } \\
\hline & No. & $\%$ & No. & $\%$ & No. & $\%$ & No. & $\%$ \\
\hline Cattle and Calves & 7,266 & 38 & 11,510 & 60 & 411 & 2 & 19,187 & 100 \\
Hogs & 1,951 & 35 & 3,597 & 64 & 73 & 1 & 5,621 & 100 \\
Sheep and Lambs & 510 & 21 & 1,918 & 79 & 13 & 1 & 2,441 & 100 \\
\hline
\end{tabular}

*Livestock delivered in the seller's own truck or in a hired truck.

\section{TABLE 24. TRANSPORTING LIVESTOCK BOUGHT BY NORTH- EASTERN FARM PRODUCERS, NORTHEASTERN UNITED STATES FARM SAMPLE, 1954 (HEAD)}

\begin{tabular}{|c|c|c|c|c|c|c|c|c|}
\hline \multirow[t]{2}{*}{ Kind of Livestock } & \multicolumn{2}{|c|}{ Buyer Delivered* } & \multicolumn{2}{|c|}{ Seller Delivered } & \multicolumn{2}{|c|}{ No Answer } & \multicolumn{2}{|c|}{ Total } \\
\hline & No. & $\%$ & No. & $\%$ & No. & $\%$ & No. & $\%$ \\
\hline Cattle and Calves ... & 1,674 & 54 & 1,061 & 34 & 357 & 12 & 3,092 & 100 \\
\hline Hogs ___ _ _ _ & 657 & 61 & 377 & 35 & 40 & 4 & 1,074 & 100 \\
\hline Sheep and Lambs & 113 & 71 & 45 & 28 & 2 & 1 & 160 & 100 \\
\hline
\end{tabular}

* Livestock delivered in the buyer's truck or in a hired truck.

7 On 63 per cent of all questionnaires, this question was left blank. Enumerators were instructed to leave it blank only if the respondent gave no answer and to enter "no" if the respondent said no. It is now known that some enumerators left blank spaces when the interviewee actually said no, but there is no reliable way of isolating the no's from no answer. In view of this, questions that were left blank have been combined under no answer. 


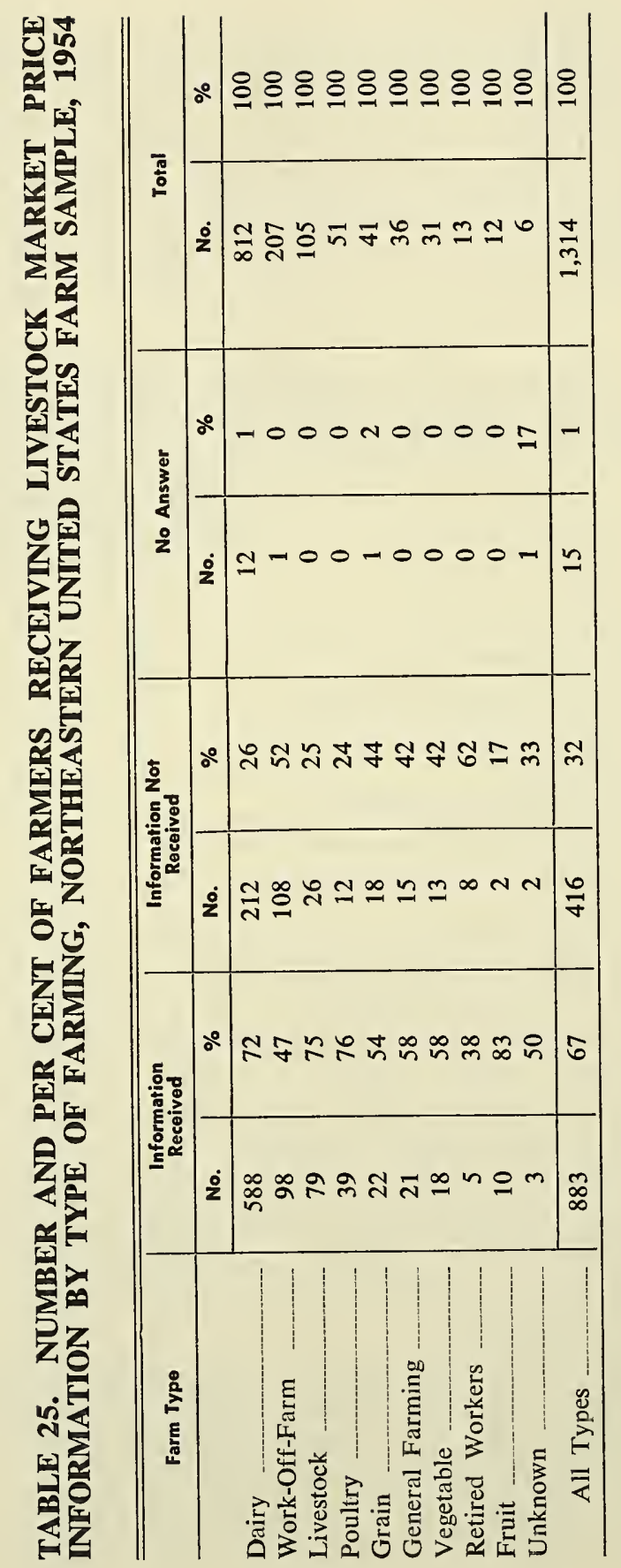


cent listed newspapers as a source of information, 57 per cent listed radio, and 18 per cent listed farm magazines (Table 26). For those receiving information, more than three-fourths said it met their needs, one-sixth said it did not, and 4 per cent expressed no opinion (Table 27).

The data in Table 28 are not conclusive enough to indicate a need for more livestock market information. Only 15 per cent of all respondents indicated a positive need for more information, and one-fourth stated positively that they were satisfied with the present market information. ${ }^{7}$

\section{TABLE 26. SOURCES OF LIVESTOCK MARKET PRICE INFOR- MATION FOR PRODUCERS RECEIVING INFORMATION, NORTH- EASTERN UNITED STATES FARM SAMPLE, 1954}

\begin{tabular}{l|c|c}
\hline \multicolumn{1}{c|}{ Sources } & $\begin{array}{c}\text { Number of Respondents } \\
\text { Receiving Information } \\
\text { From Each Source }\end{array}$ & $\begin{array}{c}\text { Per Cent of Total } \\
\text { Receiving Information } \\
\text { From Each Source }\end{array}$ \\
\hline Newspapers & 614 & 70 \\
Radio & 500 & 57 \\
Farm Magazines & 156 & 18 \\
U.S.D.A. Market News Report & 64 & 7 \\
Market Letters from Commission Agencies & 25 & 3 \\
Television & 23 & 3 \\
Inquiries and Local Sources & 16 & 2 \\
\hline Total Number Receiving Information & $883 *$ & \\
\hline
\end{tabular}

* Many respondents listed two or more sources of information.

\section{REASONS FOR SELLING LIVESTOCK}

The most commonly quoted reason for selling livestock was "ready for market" (Table 29). It is debatable that this reason answers the question asked. From the appearance of some animals that have been sold on public markets, it is highly questionable whether the livestock or the farmer were ready. "Ready for market" has different meanings among farmers. Often its meaning depends upon the type of farming and particular kind of livestock enterprise carried out by an individual producer. To livestock farmers feeding beef-type cattle for slaughter, "ready for market" probably means that the animal is carrying the finish and grade demanded by the market. To dairy farmers, it may mean that the dairy cows are dry and at relatively heavy weights, or the bob calves are six hours old.

A sizeable number of calves were sold because farmers had no desire to raise them, their parents were poor producers, they were bull calves, and producers felt they could obtain more income from selling milk as milk rather than marketing it through calves.

Many of the livestock were sold because they were "culls." Again an animal may be called a cull for one of many reasons. Very likely, 


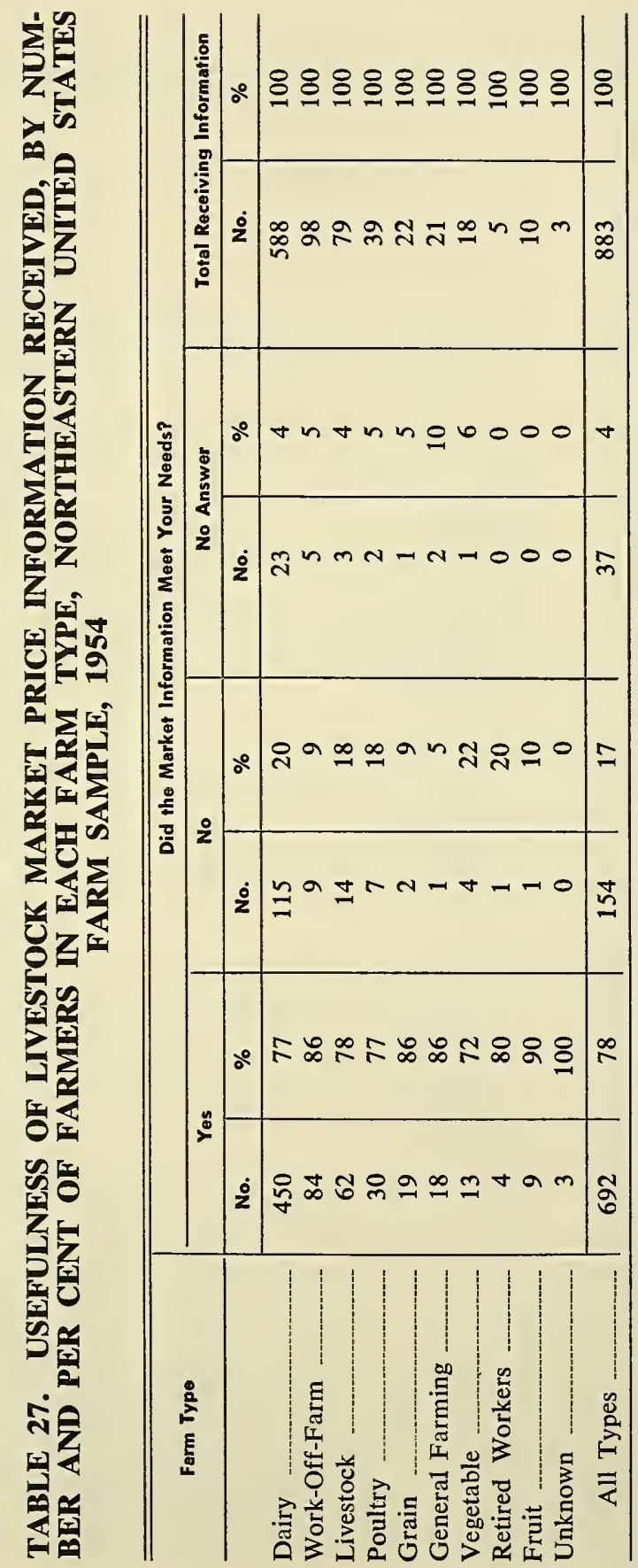




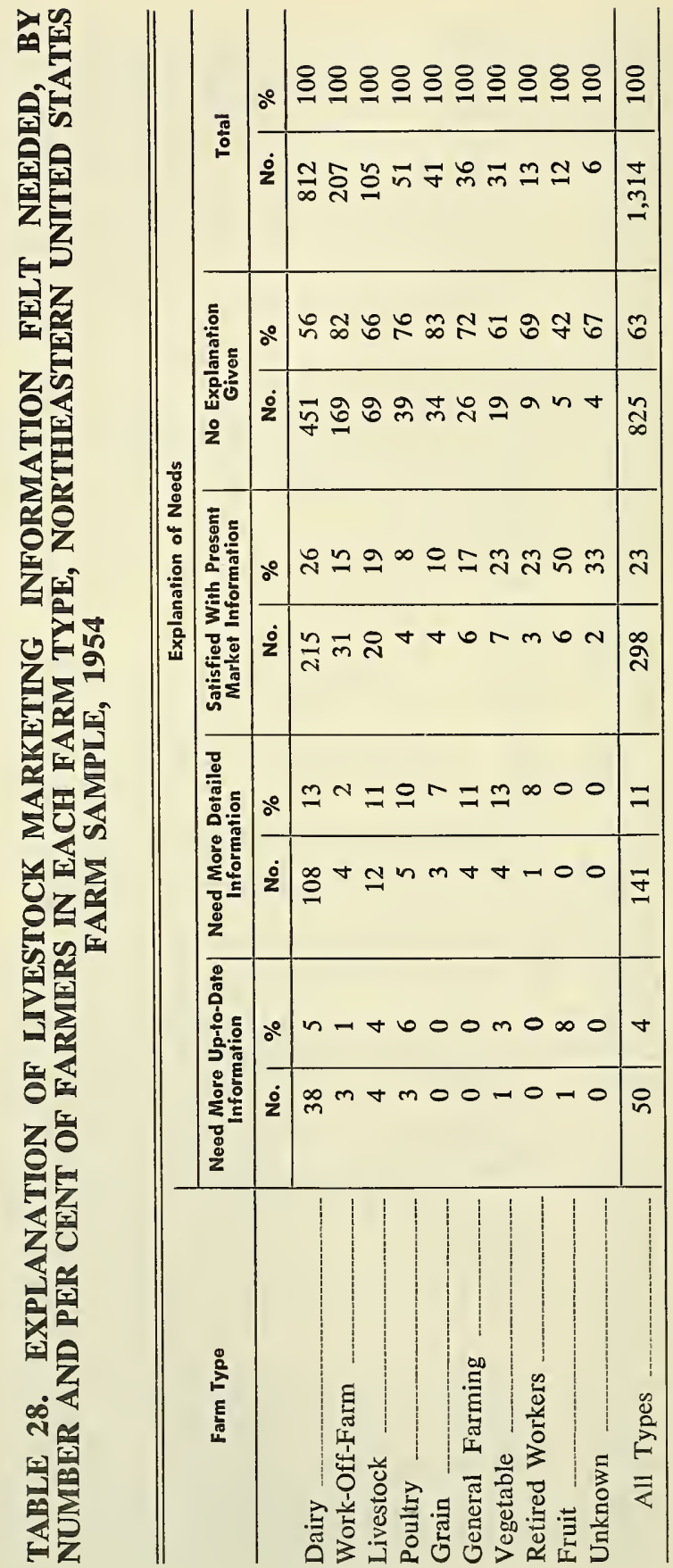


뭉

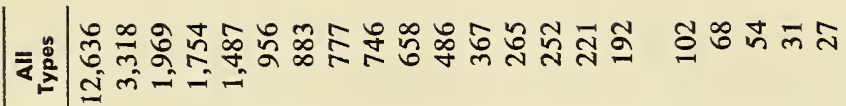

$\sum_{2}^{0}$

द年

踏

뇌

:

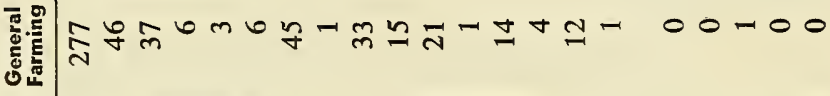
mon

$\rightarrow 0$

$\geqslant$

늘

2

ह

产

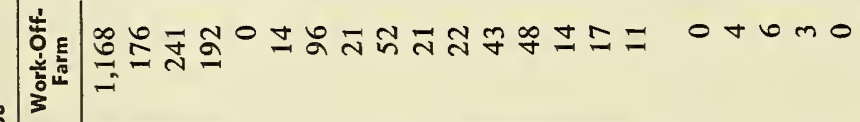

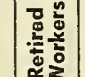

要造

ลิ่

되

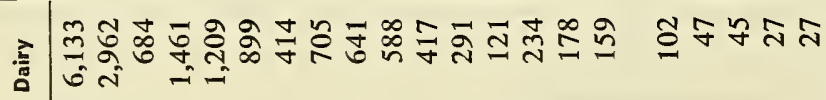

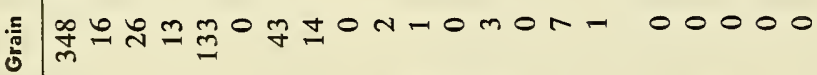
要

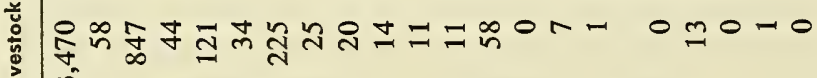
党

$7-80-000000 n 000000-00$

5

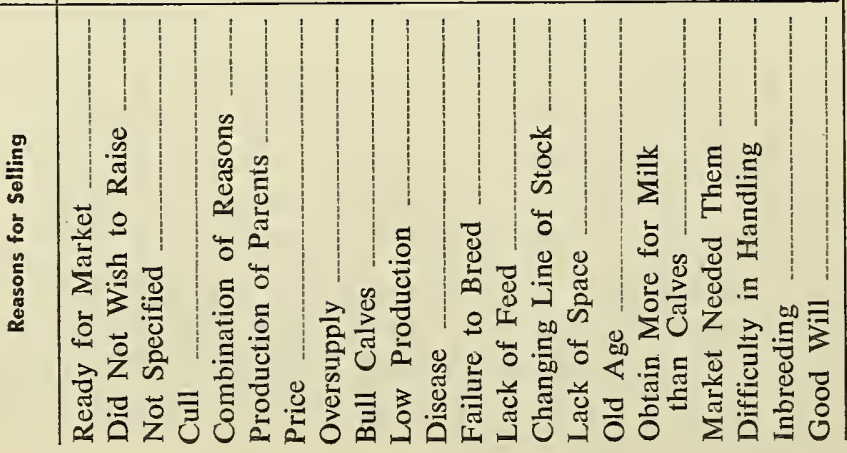


animals were termed culls for some of the more specific reasons listed in Table 29, such as low production, disease, old age, failure to breed, and difficulty in handling.

\section{CONDITION OF ANIMALS SOLD}

Among beef-type cattle of the same grade, prices paid for steers are generally a few dollars more per hundred pounds than prices paid for cows and heifers. Further, prices are usually lower for dairy-type cows and heifers than for beef-type cows and heifers due to lower meat quality and dressing percentages. Aside from differentials paid because of differences in meat quality and dressing percentages, which probably accounts for most of the variation in prices, some buyers state that cow and heifer prices are also discounted because these animals are often in an advanced stage of pregnancy when sold and this in turn lowers the dressing percentage. The evidence in Table 30 indicates that half of the cows and heifers sold were carrying calves and half were not. In view of these data, buyers are probably justified in discounting half of the females sold. When animals are being purchased, however, it is sometimes difficult to ascertain if a certain animal is carrying a calf. This is especially true among cows with large roomy stomachs. Consequently, there may be a tendency to discount all cows and heifers as an insurance factor and to the extent that there is such a policy, those producers who sell cows and heifers that are not pregnant receive lower returns than they should.

The data in Table 30 also show that more dairy cows are sold when milking than are sold when dry. The evidence also points out the failure of farmers to keep production records. Less than 10 per cent of all dairy cows sold had milk and butterfat production records.

Slightly more than half of the respondents ( 54 per cent) indicated they had a feeding program for finishing slaughter cattle (Table 31). Most commonly it was pasture alone or in combination with some grain. Only 12 per cent of the producers finished livestock on grain alone, and the period of feeding grain was usually 151 day or more (Table 32).

In the immediate 12 hours prior to selling livestock, producers sometimes "fill" their animals to increase marketing weights. Experienced buyers can detect excessive fill in livestock and those animals which have been given extra feed are generally discounted in price. From a regional viewpoint, there is no indicated problem with excessive filling. The data in Table 33 show that only 2 per cent of all producers fill their livestock, and 5 per cent actually remove their animals from feed in the 12 hours before they are sold. 


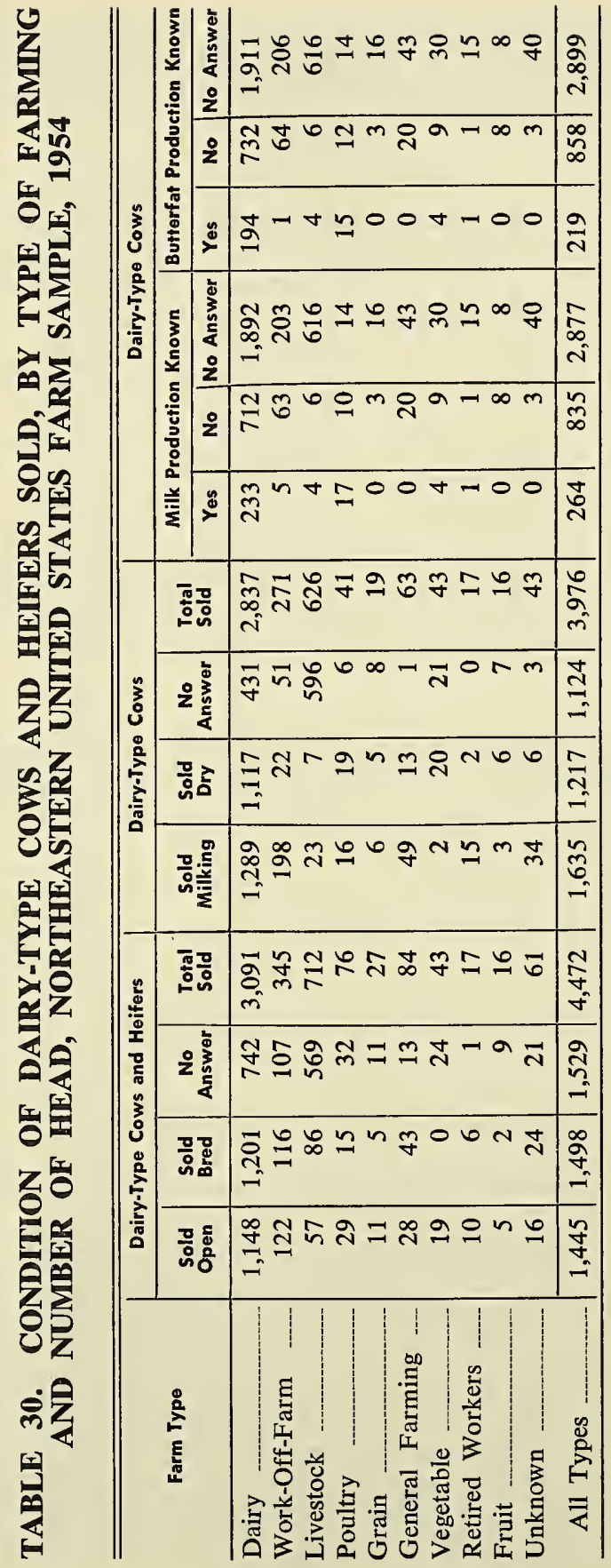


TABLE 31. FEEDING PROGRAM FOR FINISHIING SLAUGHTER CATTLE, BY NUMBER AND PER CENT OF FARMERS IN EACH FARM TYPE, NORTHEASTERN UNITED STATES FARM SAMPLE, 1954

\begin{tabular}{|c|c|c|c|c|c|c|c|c|}
\hline \multirow{3}{*}{ Ferm Type } & \multicolumn{8}{|c|}{ Feeding Program } \\
\hline & \multicolumn{2}{|c|}{ Pasture Alone } & \multicolumn{2}{|c|}{ Pasture and Grain } & \multicolumn{2}{|c|}{ Grain Alone } & \multicolumn{2}{|c|}{ No Answer } \\
\hline & No. & $\%$ & No. & $\%$ & No. & $\%$ & No. & $\%$ \\
\hline Dairy & 142 & 17 & 156 & 19 & 69 & 8 & 445 & 55 \\
\hline Work-Off-Farm & 73 & 35 & 42 & 20 & 19 & 9 & 73 & 35 \\
\hline Livestock & 39 & 37 & 26 & 25 & 27 & 26 & 13 & 12 \\
\hline Poultry & 16 & 31 & 6 & 12 & 10 & 20 & 19 & 37 \\
\hline Grain & 5 & 12 & 12 & 29 & 11 & 27 & 13 & 32 \\
\hline General Farming & 12 & 33 & 3 & 8 & 8 & 22 & 13 & 36 \\
\hline Vegetable & 8 & 26 & 4 & 13 & 8 & 26 & 11 & 35 \\
\hline Retired Workers - & 8 & 62 & 一 & - & - & - & 5 & 38 \\
\hline Fruit & 2 & 17 & 6 & 50 & 一 & - & 4 & 33 \\
\hline Unknown & 1 & 17 & 1 & 17 & - & - & 4 & 67 \\
\hline All Types & 306 & 23 & 256 & 19 & 152 & 12 & 600 & 46 \\
\hline
\end{tabular}

TABLE 32. NUMBER OF DAYS LIVESTOCK WERE FED GRAN, NORTHEASTERN UNITED STATES FARM SAMPLE, 1954

\begin{tabular}{cc|r|r}
\hline & $\begin{array}{c}\text { Feeding Period } \\
\text { (Days) }\end{array}$ & \multicolumn{2}{|c}{ Respondents } \\
\hline 0 & & 1,031 & 78 \\
$1-30$ & & 32 & 2 \\
$31-60$ & & 61 & 5 \\
$61-90$ & 48 & 4 \\
$91-150$ & 12 & 1 \\
151 and over & 130 & 10 \\
\hline
\end{tabular}

\section{INSPECTION OF LIVESTOCK SOLD}

Producers in the Northeast do not generally have their livestock inspected by veterinarians before they are sold (Table 34). As a rule this is only done to comply with the requests of certain buyers. For instance, farmers buying replacement stock for dairy herds often demand that the cows be given tests for brucellosis. Hog feeders generally request that feeder pigs be given cholera shots. During 1954 producers made arrangements to have 15 per cent of the cattle and calves and 8 per cent of the hogs inspected by veterinarians. 


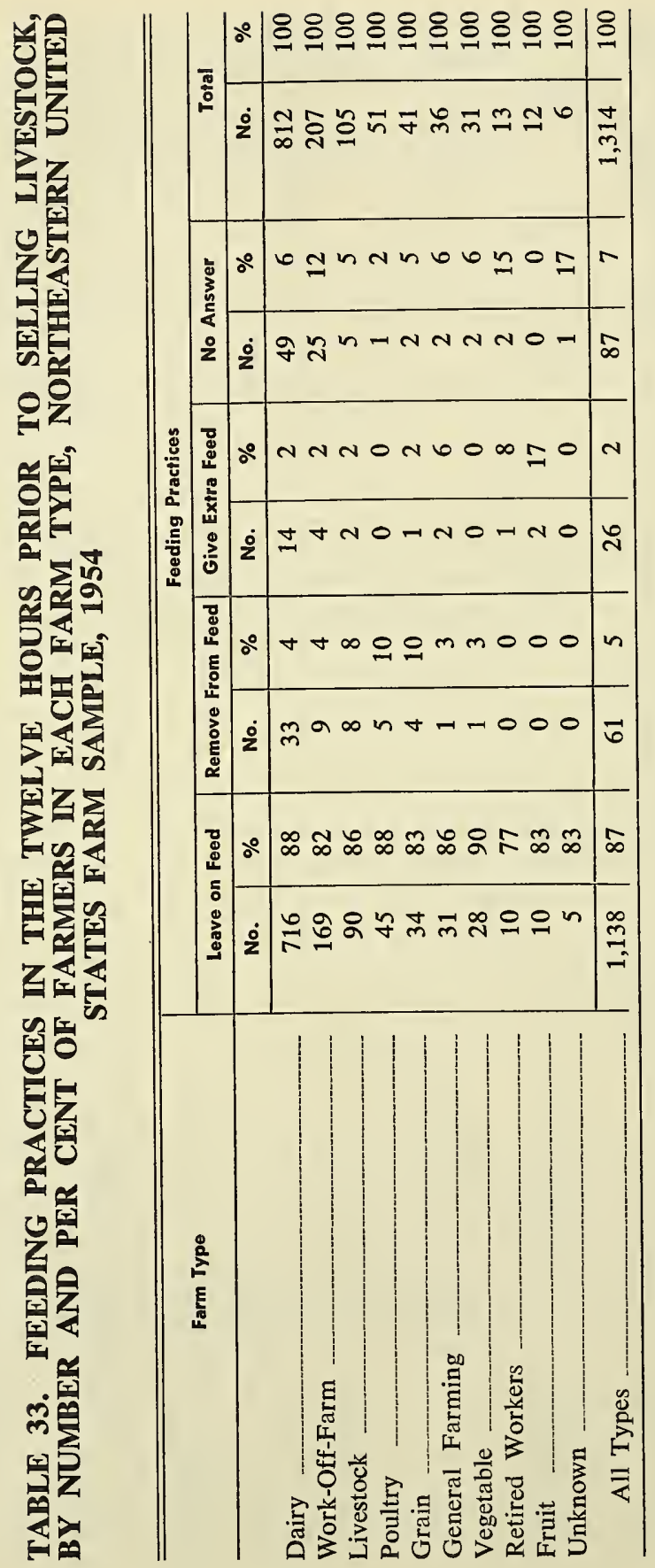




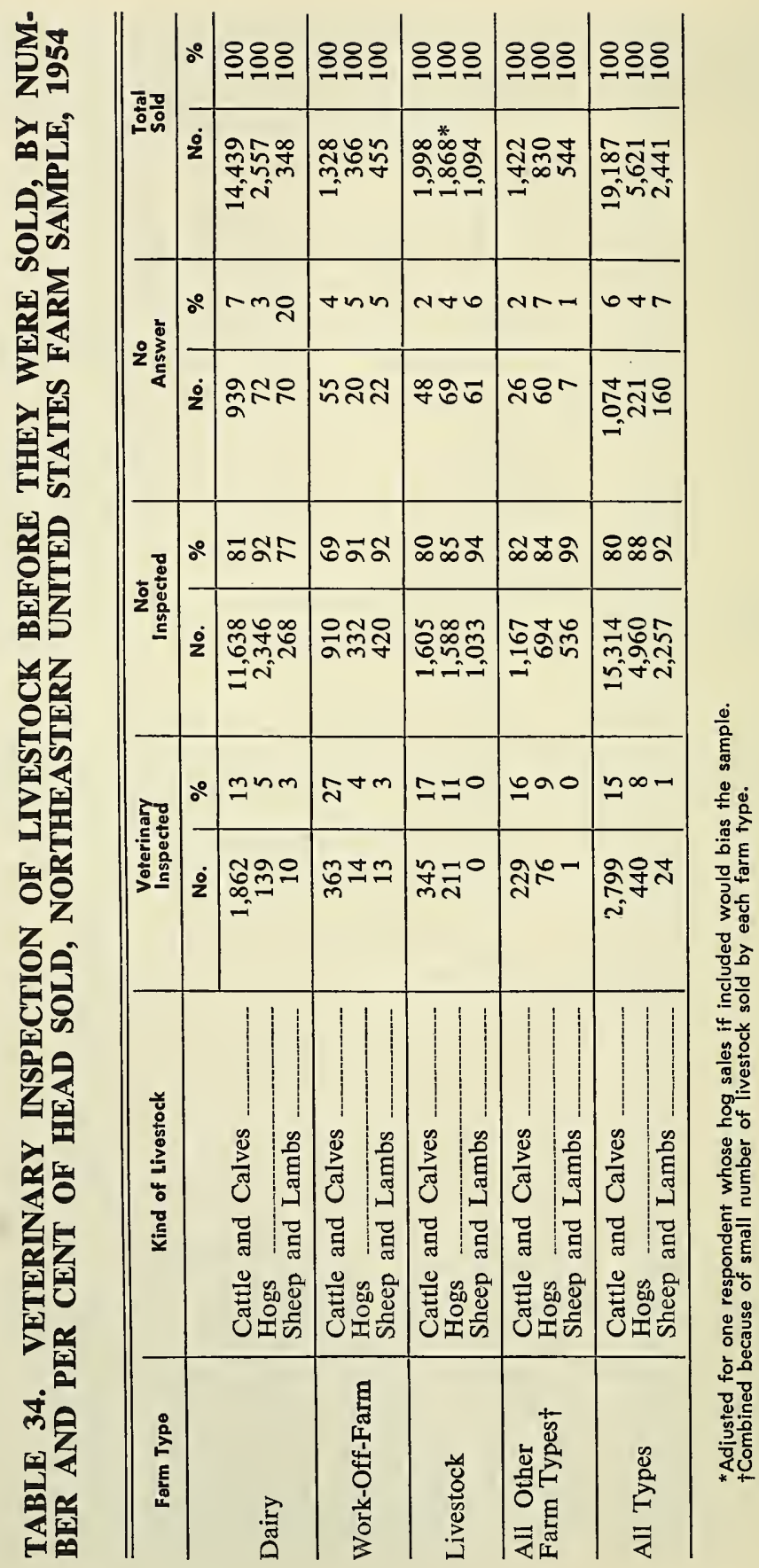




\section{AGE OF LIVESTOCK SOLD}

The age of livestock sold varies considerably between kinds of livestock and among classes within any one kind of livestock. Some of the more important factors contributing to the variations are the time required for each kind of slaughter animal to reach maturity, type of farming program carried out by the producer, production ability of animals, and the occurrence of disease or ill health. Slaughter hogs and lambs usually attain market weights and are sold by the time they are six months of age. Slaughter steers and heifers, excluding baby beeves, do not as a rule reach desirable market weights and grades until they are over one year of age. Farmers who have animals for milk production often raise only enough calves for herd replacements and sell all other calves before they are a week old. In many cases milk producers sell all calves before they are a week old and buy all of their replacement stock. Dairy cows are usually five or more years old when sold and in general are marketed because of low production. Some cattle are sold at all ages because of brucellosis, mastitis, hardware trouble, or other injuries and diseases, but these animals make up a small proportion of all animals sold.

During 1954 nine out of every ten dairy calves were sold by the time they were three months old. In fact, 60 per cent of the dairy calves were less than 5 days old when sold and another 39 per cent were between 5 days and 3 months old when sold. Very few dairy cattle and calves between the ages of three months and two years were sold (Table 35). As explained above, most of the calves retained by milk producers were for herd replacements and unless they became sick or the farmer was confronted with an unusual situation for making a profit or obtaining funds, these animals would be two years old or more before their production could be ascertained. At that time they might be sold due to low production, failure to breed, or other reasons.

The data in Table 35 show that a considerable number of the hogs sold by Northeast producers were sold as feeder pigs. About equal numbers of slaughter hogs were sold when six months to a year of age as were sold 3 to 6 months of age. Slaughter hogs would normally be ready for the market before they were 6 months of age. The data suggest that many farmers required a longer period of time than normally recommended for producing hogs to desirable market weights.

A majority of the beef-type cattle were one year old or over when sold. More than half of the dairy calves were under five days of age when sold, but less than 3 per cent of the beef calves were under 5 days of age when sold.

Approximately two-thirds of all lambs sold were between the ages of 3 and 6 months. Some feeder lambs were sold before 3 months of 


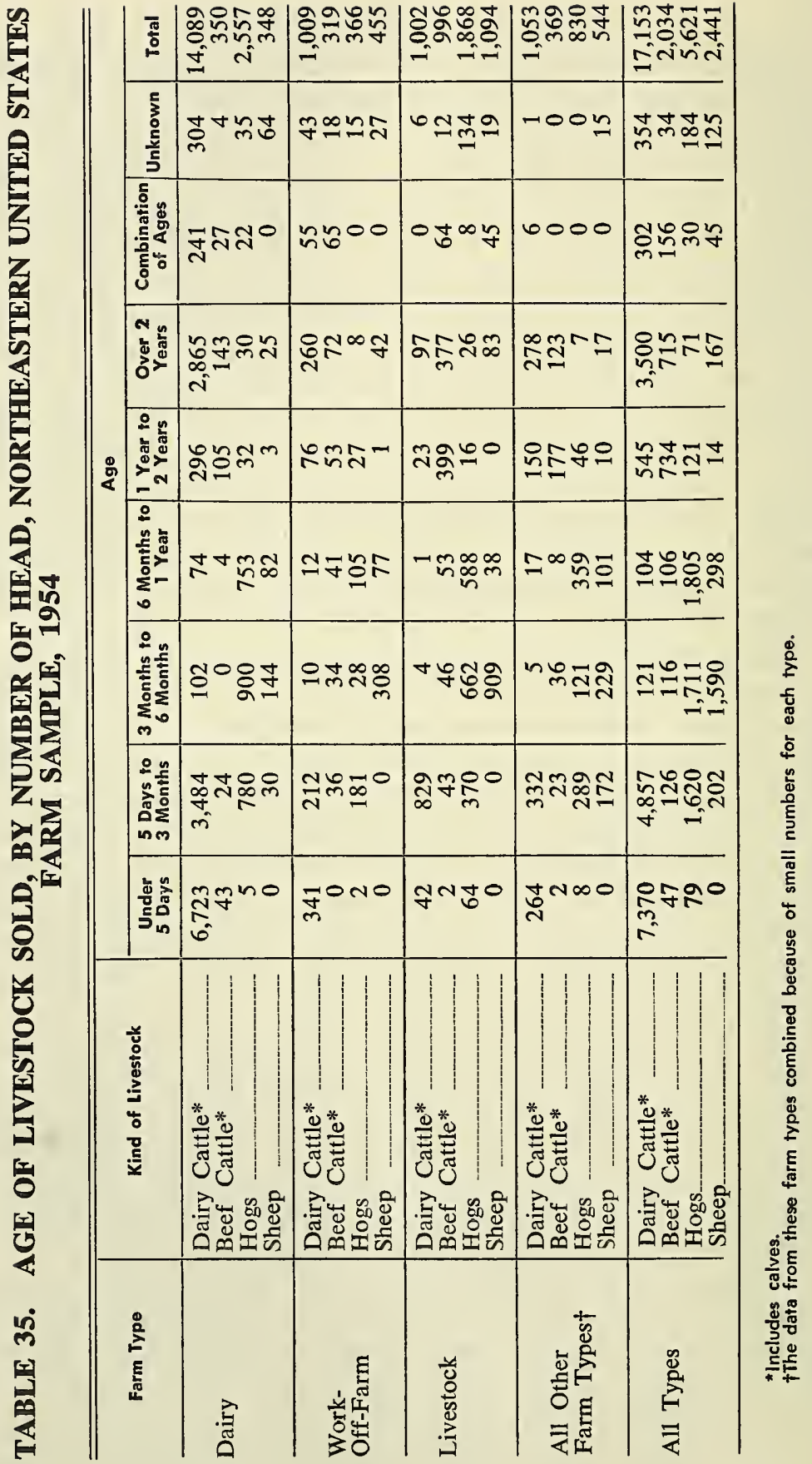


age and some slaughter lambs required more than 6 months to reach desirable market weights and grades.

\section{SEASONALITY OF SALES}

The data on all lots of livestock sold during each month were combined to point out the seasonal marketings of livestock. For all farm types and for all livestock there was a minor peak in lots of livestock marketed in the spring months of March and April followed by a period of relatively low numbers of lots marketed in June, July, and August (Table 36). During September, October, and November, the number of lots marketed rose to an annual peak and then declined in December, January, and February to their annual low.

The secondary peak of marketings in the spring was largely due to the increased number of calves being marketed by dairy farmers. At the same time, producers were culling some low-producing cows from their herds. During the major marketing peak in September, October, and November, the marketings of beef-type cattle, hogs, dairy calves, and cull dairy animals were all increased.

\section{LOT SIZE}

The number of animals in each lot sold by a Northeast farmer varies considerably with the kind and class of livestock sold and the rules, regulations, and customs followed in each state. Some states have arrangements for selling vealers, lambs, and hogs in pooled lots. These lots are pooled according to grades assigned livestock by state graders. Farmers have the option of allowing their animals to be pooled or sold one at a time. In other states habits and customs of buyers and sellers prevent the buying and selling of several animals in one lot. In general, replacement stock and slaughter cattle are sold in lots containing one animal, while calves, lambs, and hogs are sold in either single or multiple numbers per lot.

During 1954 more than 60 per cent of the cattle and calf lots sold contained one animal each and about 85 per cent of all lots had 5 head or less (Table 37). For all cattle and calves sold, the average lot size was 3.6 head. The average size of hog lots was much larger-just over 13 head. Sheep lots averaged 12 head per lot sold. Even among hogs and sheep, the proportion of lots containing 5 head or under was rather high, amounting to more than 40 per cent of all lots in each case.

\section{TYPE SALE}

The method used most frequently in selling livestock varied among states and among markets. At some markets practically all animals were sold by the head, while selling by weight predominated at others. The 


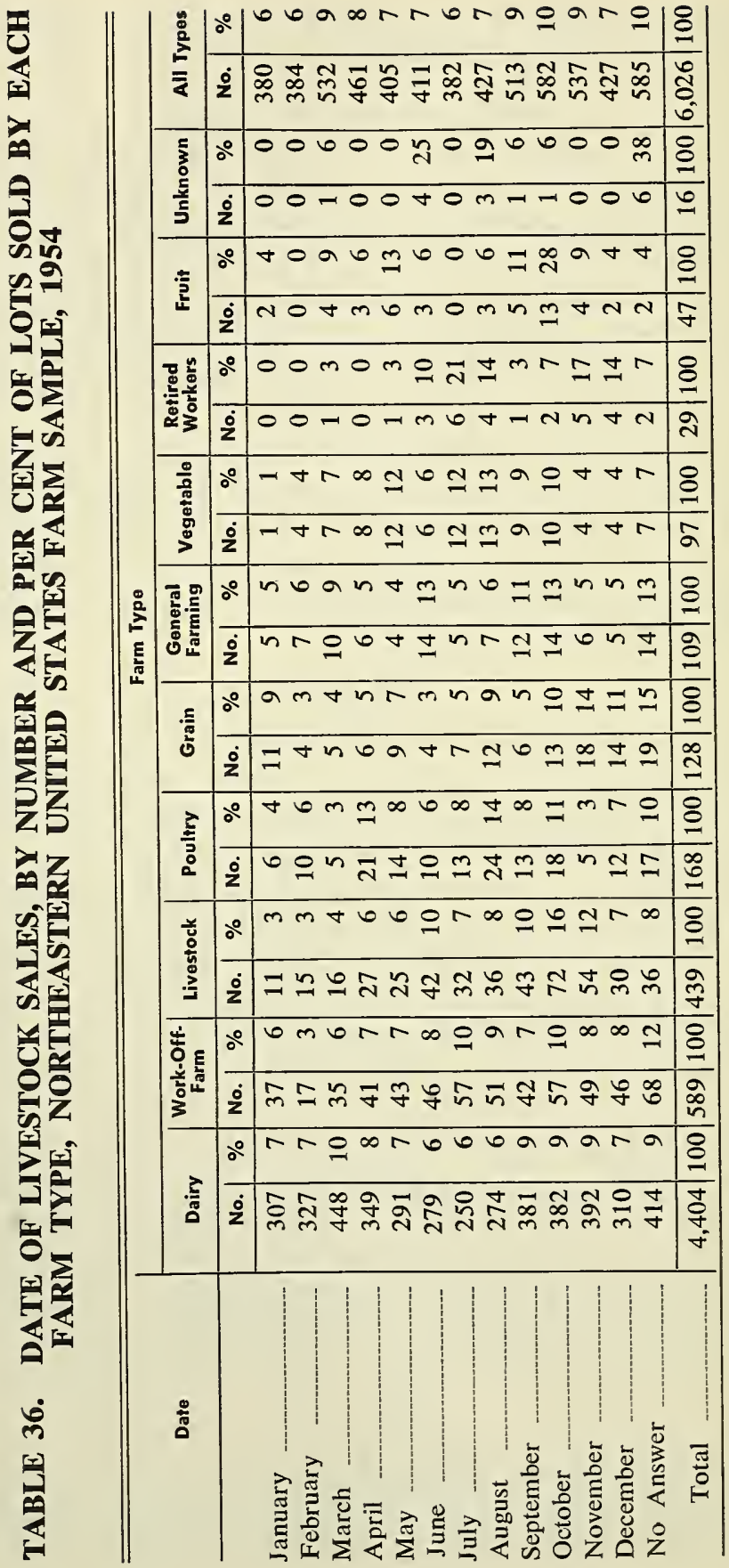




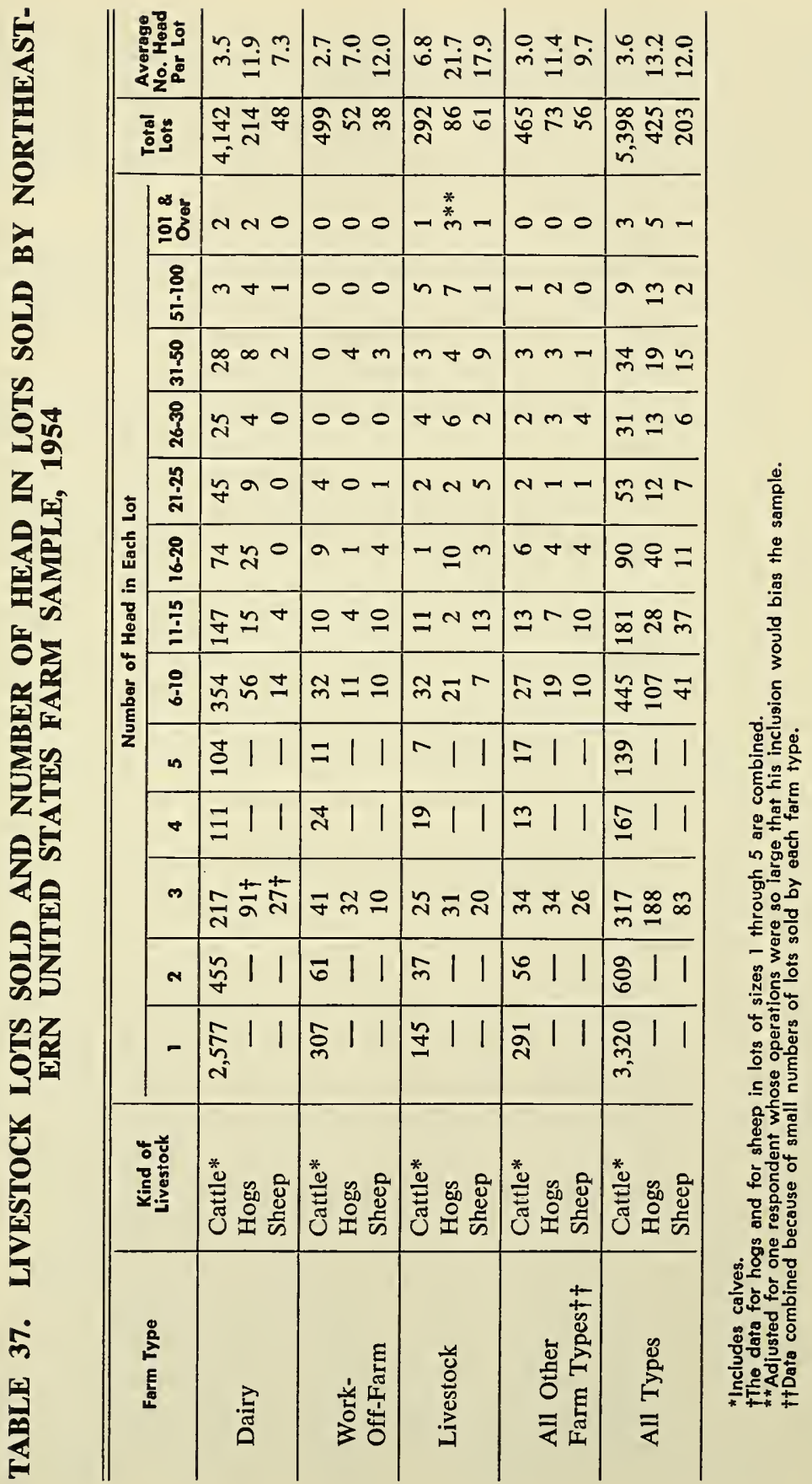


data in Table 38 show that more than 60 per cent of the dairy cattle were sold by the head and 25 per cent by weight. Since these animals constitute a major portion of all livestock sold, figures for hogs, sheep, and beef cattle were not obtained. It is estimated, however, that the proportion of all livestock sold by the head would still be substantially above 50 per cent if all livestock had been accounted for.

Among the farm types, there was a slight difference in the method of selling dairy animals. Livestock farmers sold a major proportion of their dairy cattle by weight, while 8 of the 10 farm types, including dairy farmers, sold a majority of their animals by the head.

At public livestock markets, animals were usually sold on a cash basis. Livestock sales between farmers and sales by dealers to farmers were sometimes made on a credit basis. The data in Table 38 show that more than 95 per cent of the dairy animals were sold for cash. As pointed out in Table 20 very few dairy animals were sold to other farmers. This may be one reason why credit sales were such a small percentage of the total sales.

It was pointed out earlier that very few farmers have their livestock veterinary-inspected before selling them. Many of these animals will be sold at auctions, however, and a large number of the auctions have veterinary services either for all livestock sold or for replacement stock. Although this is an invaluable safeguard against disease and ill health, it offers no protection against poor-producing stock, and the inspecting service, valuable as it is, does not extend to all markets and all livestock sold. As a rule farmers do not furnish any type of written or oral description guaranteeing health, breeding, or production. Nearly all cattle and calves ( 96 per cent), all sheep, and 99 per cent of all hogs were sold "as is" (Table 39). Under these circumstances, it is understandable why so many farmers interested in improving herd production prefer to raise their own replacements or else buy them from sources they consider highly reliable. Farmers who do buy replacements at public markets where there are no veterinary services nor statements available concerning the breeding and production of animals probably have their qualms during some periods thinking that they may have bought livestock which are poor producers or worse yet, diseased animals.

\section{FARMERS' OPINIONS ABOUT CHOICE OF OUTLET, PRICES RECEIVED, AND MARKETING SERVICES}

Communications have become so instantaneous, transportation so rapid, rules and regulations so standardized and encompassing, and refrigeration so adaptable and commonplace that differences in livestock prices among markets are probably mere reflections of transportation or quality differentials. Of course, occasional market price imperfections 


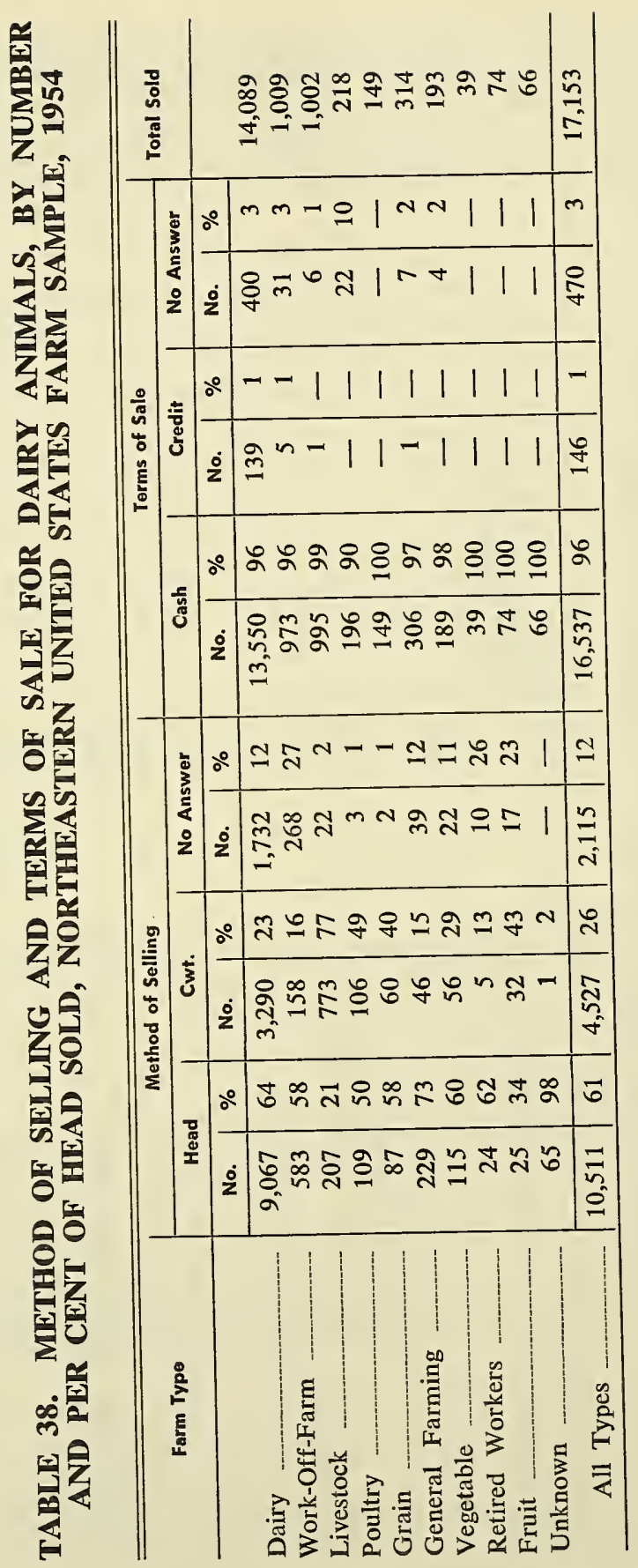




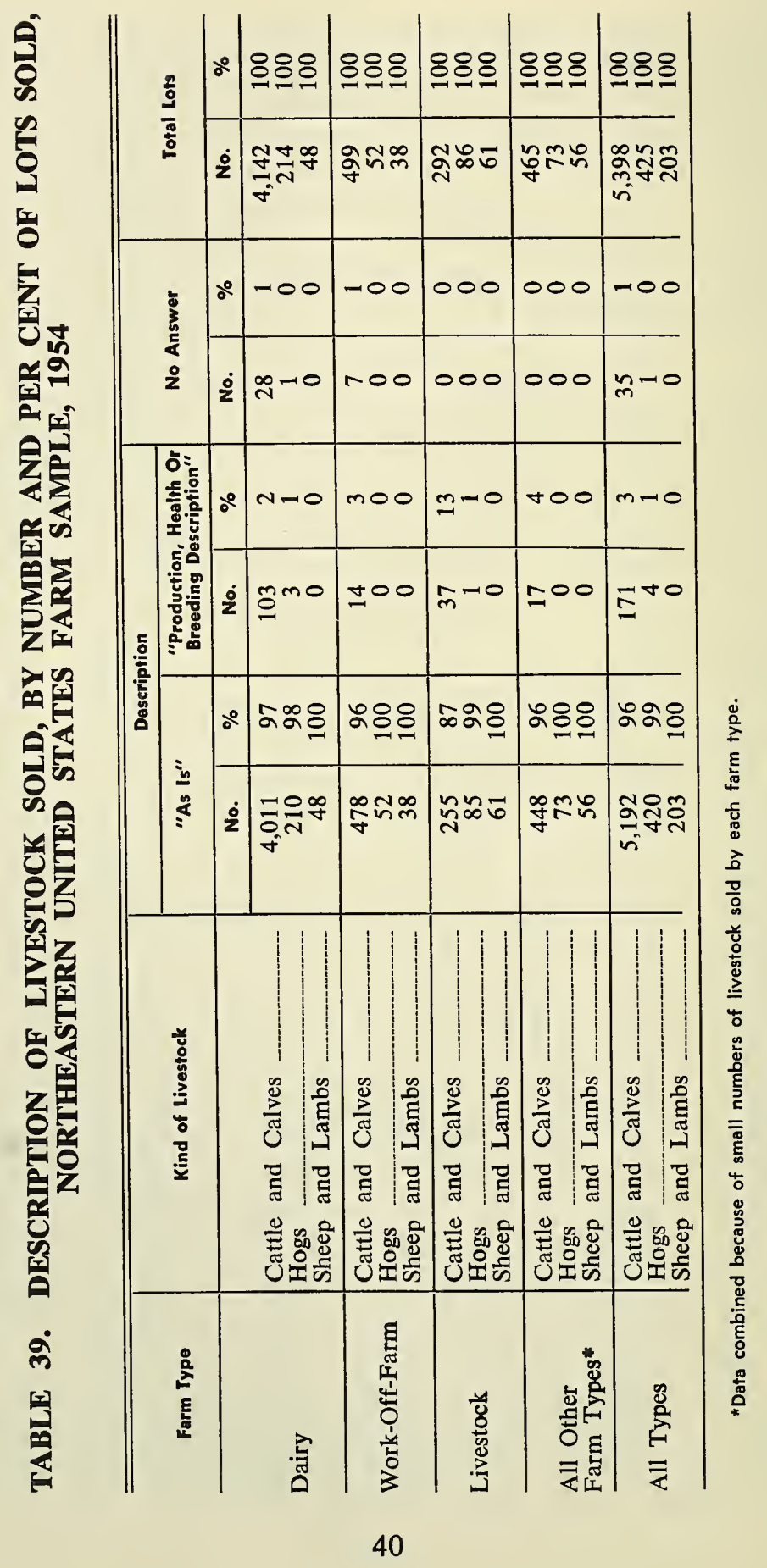


exist, but they appear to be short-run market corrections, and even these are apparently becoming fewer and fewer and their duration shorter and shorter. Each farmer plays a role in this equalization of market prices by keeping informed on prices, weights, grades, etc. at alternative markets and then selling his livestock at or to those agencies which he feels will return the greatest net profit.

The data in Tables 40 through 44 point out that factors other than price for animals influence a large number of farmers in their choice of market. However, many farmers believe that there are differences in livestock prices between markets and these farmers apparently sell their stock at or to markets which they believe pay the "best price."

Price, however, was not listed as the most important reason for selling livestock to certain agencies (Tables 40,41, 42, 43, and 44). It was the most important reason for selling livestock through terminals, but for all other outlets, it was second in importance. "Convenience" was listed as the most important reason for selling to or through all outlets except terminals. Indirectly, this lends support to the suggestion that differences in livestock prices among markets are likely based on quality or transportation differentials. "Convenience and best price" was ranked as the third most important factor influencing the choice of market. "Habit" was the only other major reason given for selling livestock to certain outlets.

\section{TABLE 40. REASONS FOR SELLING LIVESTOCK THROUGH AUCTIONS, BY NUMBER OF LOTS SOLD, NORTHEASTERN UNITED STATES FARM SAMPLE, 1954}

\begin{tabular}{|c|c|c|c|c|c|}
\hline \multirow[b]{2}{*}{ Reasons for Selling } & \multicolumn{5}{|c|}{ Farm Type } \\
\hline & Dairy & $\begin{array}{c}\text { Work-Off- } \\
\text { Farm }\end{array}$ & Livestock & $\begin{array}{c}\text { All Other } \\
\text { Farm Types* }\end{array}$ & All Types \\
\hline Convenience & 1,272 & 129 & 120 & 110 & 1,631 \\
\hline Best Price & 511 & 40 & 81 & 44 & 676 \\
\hline Convenience and Best Price & 270 & 39 & 14 & 16 & 339 \\
\hline Habit & 76 & 110 & 1 & 6 & 193 \\
\hline No Alternative Market & 39 & 2 & 3 & 6 & 50 \\
\hline Honesty & 21 & 0 & 1 & 1 & 23 \\
\hline New Market & 14 & 2 & 0 & 4 & 20 \\
\hline Combination of Reasons & 8 & 0 & 0 & 0 & 8 \\
\hline Agreement & 2 & 2 & 0 & 0 & 4 \\
\hline Club Sale & 2 & 0 & 1 & 1 & 4 \\
\hline Public Relations & 4 & 0 & 0 & 0 & 4 \\
\hline Market Needs Them & 1 & 0 & 0 & 0 & 1 \\
\hline No Answer _ & 137 & 28 & 6 & 52 & 223 \\
\hline
\end{tabular}

*All other farm types combined because of the small number of lots sold by each farm type. 


\section{TABLE 41. REASONS FOR SELLING LIVESTOCK TO LIVE- STOCK DEALERS, BY NUMBER OF LOTS SOLD, NORTHEASTERN UNITED STATES FARM SAMPLE, 1954}

\begin{tabular}{|c|c|c|c|c|c|}
\hline \multirow[b]{2}{*}{ Reasons for Selling } & \multicolumn{5}{|c|}{ Farm Type } \\
\hline & Dairy & $\begin{array}{c}\text { Work-Off- } \\
\text { Farm }\end{array}$ & Livestock & $\begin{array}{c}\text { All Other } \\
\text { Farm Types* }\end{array}$ & All Types \\
\hline Convenience & 383 & 34 & 27 & 53 & 497 \\
\hline Best Price & 211 & 29 & 7 & 27 & 274 \\
\hline Habit & 98 & 21 & 0 & 12 & 131 \\
\hline Convenience and Best Price & 102 & 6 & 0 & 7 & 115 \\
\hline No Alternative Markets & 31 & 2 & 0 & 4 & 37 \\
\hline Honesty & 18 & 1 & 0 & 9 & 28 \\
\hline Market Needs Them & 22 & 0 & 2 & 1 & 25 \\
\hline Combination of Reasons & 13 & 0 & 0 & 0 & 13 \\
\hline Exchange & 7 & 0 & 0 & 3 & 10 \\
\hline Public Relations & 5 & 2 & 0 & 0 & 7 \\
\hline New Market & 3 & 0 & 0 & 0 & 3 \\
\hline Agreement & 2 & 0 & 0 & 0 & 2 \\
\hline No Answer & 77 & 7 & 7 & 23 & 114 \\
\hline
\end{tabular}

*All other farm types combined because of the small number of lots sold by each farm type.

TABLE 42. REASONS FOR SELLING LIVESTOCK AT TERMUNAL MARKETS, BY NUMBER OF LOTS SOLD, NORTHEASTERN UNITED STATES FARM SAMPLE, 1954

\begin{tabular}{|c|c|c|c|c|c|}
\hline \multirow[b]{2}{*}{ Reasons for Selling } & \multicolumn{5}{|c|}{ Farm Type } \\
\hline & Dairy & $\begin{array}{c}\text { Work-Off- } \\
\text { Farm }\end{array}$ & Livestock & $\mid$\begin{tabular}{c|} 
All Other \\
Farm Types*
\end{tabular} & All Types \\
\hline Best Price & 87 & 19 & 28 & 10 & 144 \\
\hline Convenience & 22 & 5 & 13 & 10 & 50 \\
\hline Convenience and Best Price & 5 & 0 & 0 & 17 & 22 \\
\hline No Alternative Markets & 9 & 0 & 0 & 6 & 15 \\
\hline Habit & 6 & 2 & 0 & 0 & 8 \\
\hline New Market & 1 & 0 & 0 & 1 & 2 \\
\hline Combination of Reasons & 1 & 1 & 0 & 0 & 2 \\
\hline Honesty & 1 & 0 & 0 & 0 & 1 \\
\hline Advised of Market & 1 & 0 & 0 & 0 & 1 \\
\hline No Answer & 18 & 1 & 4 & 4 & 27 \\
\hline
\end{tabular}

*All other farm types combined because of the small number of lots sold by each farm type.

Looking closer at the "convenience" factor, it becomes apparent that this is either a location or time convenience factor. Since it was an openended question and no depth probing was attempted, it is impossible to be sure how many of the lots were sold for one or the other convenience factors. "Best price" is in this same type of category. It could mean the highest gross price, the highest net price, or it could be some price in between. At the same time, it could refer to the highest price paid 
TABLE 43. REASONS FOR SELLING LIVESTOCK TO OTHER FARMERS, BY NUMBER OF LOTS SOLD, NORTHEASTERN UNITED STATES FARM SAMPLE, 1954

\begin{tabular}{l|c|c|c|c|c}
\hline \multicolumn{2}{c|}{ Reasons for Selling } & \multicolumn{5}{|c}{ Farm Type } \\
\cline { 2 - 6 } & Dairy & $\begin{array}{c}\text { Work-Off- } \\
\text { Farm }\end{array}$ & Livestock & $\begin{array}{c}\text { All Oother } \\
\text { Farm Types* }\end{array}$ & All Types \\
\hline Convenience & 87 & 18 & 19 & 25 & 149 \\
Best Price - & 86 & 9 & 22 & 7 & 136 \\
Market Needed Them & 40 & 6 & 8 & 6 & 60 \\
Convenience and Best Price & 17 & 4 & 0 & 4 & 25 \\
Exchange - & 5 & 1 & 0 & 0 & 6 \\
No Alternative Markets & 4 & 0 & 0 & 1 & 5 \\
Club Sales & 3 & 0 & 0 & 1 & 4 \\
Combination of Reasons & 2 & 0 & 2 & 0 & 4 \\
Agreement & 2 & 0 & 0 & 1 & 3 \\
Public Relations & 3 & 0 & 0 & 0 & 3 \\
Advised of Market & 0 & 0 & 0 & 1 & 1 \\
New Market & 1 & 0 & 0 & 0 & 1 \\
No Answer & 49 & 13 & 8 & 16 & 86 \\
\hline
\end{tabular}

*All other farm types combined because of the small number of lots sold by each farm type.

TABLE 44. REASONS FOR SELLING LIVESTOCK TO MEAT PACKERS, RELATIVES, LOCAL HOME OWNERS AND THROUGH OTHER MINOR OUTLETS, BY NUMBER OF LOTS SOLD, NORTHEASTERN UNITED STATES FARM SAMPLE, 1954

\begin{tabular}{|c|c|c|c|c|c|}
\hline \multirow[b]{2}{*}{ Reasons for Selling } & \multicolumn{5}{|c|}{ Farm Type } \\
\hline & Dairy & $\begin{array}{l}\text { Work-Off- } \\
\text { Farm }\end{array}$ & Livestock & $\begin{array}{c}\text { All Other } \\
\text { Farm Types* }\end{array}$ & All Types \\
\hline Convenience & 284 & 23 & 18 & 31 & 356 \\
\hline Best Price & 121 & 12 & 36 & 23 & 192 \\
\hline Convenience and Best Price --- & 68 & 2 & 3 & 19 & 92 \\
\hline Habit & 21 & 0 & 2 & 5 & 28 \\
\hline No Alternative Markets & 12 & 6 & 1 & 1 & 20 \\
\hline Club Sale & 16 & 0 & 0 & 0 & 16 \\
\hline Agreement & 14 & 0 & 0 & 0 & 14 \\
\hline Market Needed Them & 7 & 2 & 1 & 0 & 10 \\
\hline Honesty & 6 & 0 & 0 & 0 & 6 \\
\hline Public Relations & 3 & 0 & 0 & 0 & 3 \\
\hline Exchange & 1 & 0 & 0 & 0 & 1 \\
\hline New Market & 1 & 0 & 0 & 0 & 1 \\
\hline Combination of Reasons & 0 & 1 & 0 & 0 & 1 \\
\hline No Answer & 51 & 10 & 4 & 26 & 89 \\
\hline
\end{tabular}

*All other farm types combined because of the small number of lots sold by each farm type.

per cwt., or highest price per head of livestock sold. Again no depth probing was made, and one can only hope that "best price" means the highest net price. 
Since farmers indicated approximately the same reasons for selling livestock through or to each of the several outlets, the data may seem inconsistent at first glance. The geographical dispersion of markets and farmers is such that some farmers are closer to auctions, some closer to terminals, some closer to meat packers, etc. Therefore, "convenience" of location can be the major reason why certain groups of farmers sell their livestock to each of the several outlets.

"Best price" can also be a valid reason for selling to or through each market outlet. When the cost of transportation is taken into account, net prices received would likely be better for a particular farmer at a particular market. For example, a farmer living within five miles of one market and ten miles of another market would have lower transportation costs to sell animals at the nearest market. Assuming price equality for comparable livestock at the two markets, to sell livestock at the nearest one would, in fact, lead to the highest net price or the "best price."

Farmers, like everyone else, tend to be creatures of habit. Once a practice or procedure has been done in a certain manner for a period of time, it becomes rather automatic to continue doing it in the same old way. The same thing applies to the marketing of livestock. Some farmers consistently sell through auctions, whereas others consistently sell to dealers, even though it might occasionally be desirable to sell through or to another agency. The same applies to other farmers and other markets. Thus, habit is an associated reason for marketing livestock to or through each of the several outlets.

The data in Table 45 indicate that most livestock were sold at satisfactory prices. At the same time, producers registered satisfaction with marketing services received when selling livestock. A higher proportion of the hogs sold at satisfactory prices than either cattle or sheep. The difference in rates of satisfaction between the kinds of livestock sold may be due to the smaller price differentials among hogs when compared to the price differentials among cattle. Apparently producers feel that marketing services in the Northeast region are very good for all kinds of livestock sold and that prices are in line with their expectations.

On the basis of lots sold, more dissatisfaction with market price was registered when livestock were sold either through auctions or at private sales (Table 46). Marketing services were most unsatisfactory when livestock were sold through minor outlets such as relatives, local homeowners, and through breed dispersals. It would be interesting to know how many of the lots sold at unsatisfactory prices were deemed unsatisfactory because of "low prices" regardless of the market used. 


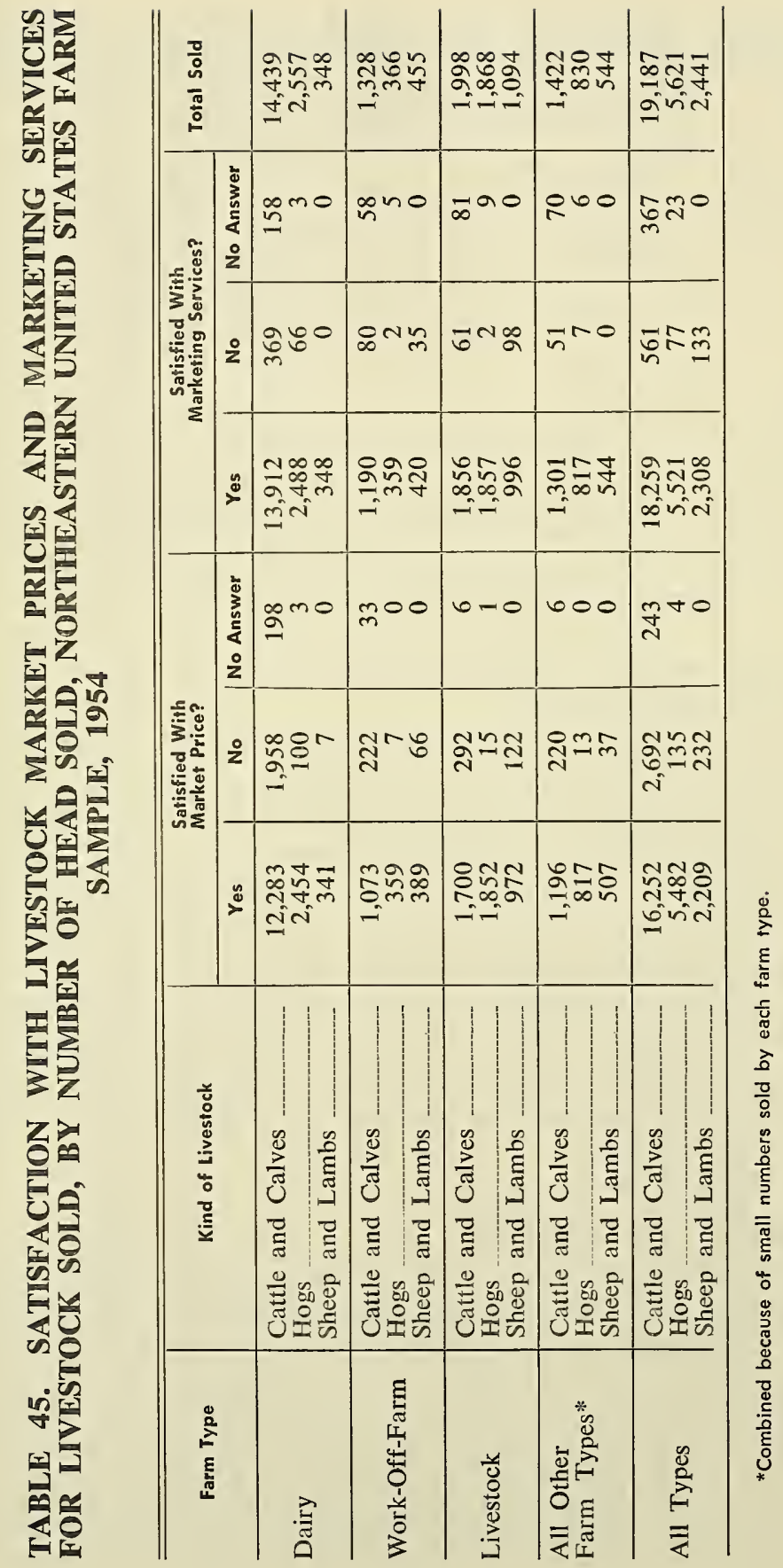


TABLE 46. SATISFACTION WITH PRICES RECEIVED AND MARKETING SERVICES FOR LIVESTOCK SOLD, BY TYPE OF OUTLET AND NUMBER OF LOTS SOLD, NORTHEASTERN UNITED STATES FARM SAMPLE, 1954

\begin{tabular}{l|r|r|r|r|r|r|r}
\hline \multirow{2}{*}{ Market Outlets } & \multicolumn{2}{|c|}{ Satisfied With Prices Received } & \multicolumn{3}{c|}{$\begin{array}{c}\text { Satisfied With } \\
\text { Marketing Services? }\end{array}$} & \multirow{2}{*}{ Total Lots } \\
\cline { 2 - 7 } & \multicolumn{1}{|c|}{ Yes } & \multicolumn{1}{|c|}{ No } & No Ans. & Yes & \multicolumn{1}{|c|}{ No } & No Ans. & \\
\hline Auctions & 2,625 & 515 & 42 & 3,002 & 146 & 34 & 3,182 \\
Dealers & 1,110 & 112 & 36 & 1,217 & 28 & 13 & 1,258 \\
Farmers & 439 & 24 & 8 & 457 & 6 & 8 & 471 \\
Packers & 384 & 32 & 2 & 409 & 6 & 3 & 418 \\
Terminals & 255 & 37 & 0 & 288 & 3 & 1 & 292 \\
Cooperatives & 214 & 7 & 0 & 207 & 14 & 0 & 221 \\
Combination* & 80 & 12 & 8 & 85 & 11 & 4 & 100 \\
Private Sale & 67 & 17 & 0 & 81 & 3 & 0 & 84 \\
\multicolumn{1}{c|}{ All Outlets } & 5,174 & 756 & 96 & 5,746 & 217 & 63 & 6,026 \\
\hline
\end{tabular}

*Includes sales to homeowners, relatives, through breed dispersals, efc.

Undoubtedly some farmers would complain that prices were too low no matter how high they were.

It appears that the large percentage of lots sold at satisfactory prices to each market lends support to the suggestion of equitable prices among markets and validates the "best price" reason given for selling to each of the markets. The data in Table 46 show that services received were most satisfactory when stock was sold through terminals, to farmers, and to dealers. Quite often livestock sold through auctions, cooperatives, and minor outlets must be transported and unloaded by the farmer when he arrives at the market. These services are generally performed by others when livestock is sold through terminals, to dealers, and other farmers. Of course, producers pay for these services, but it still does not change the fact that more services are available when selling stock through certain outlets.

\section{Livestock Procurement}

With more than 60 per cent of Northeastern farmers engaged in dairying, most of the livestock purchased during 1954 were replacement dairy animals (Table 47). Most of these were cattle rather than calves.

\section{NUMBER AND SOURCES OF LIVESTOCK PURCHASED}

For all respondents the average number of livestock animal units purchased in 1954 was slightly more than two (Table 48). The number of animal units bought by average farmers in each farm type varied from zero to just over five units. Livestock farmers bought the largest average 


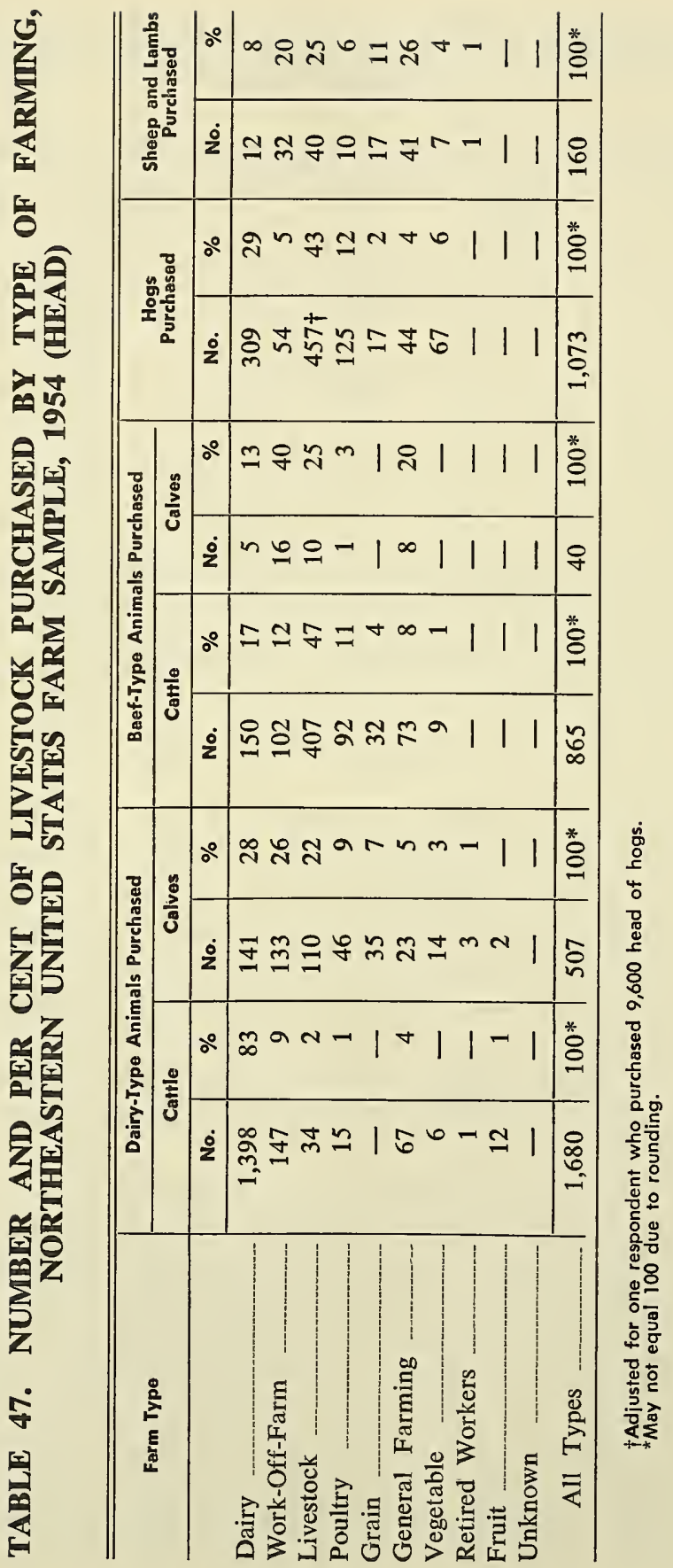




\section{TABLE 48. ANIMAL UNITS* OF LIVESTOCK PURCHASED BY EACH FARM TYPE, NORTHEASTERN UNITED STATES FARM SAMPLE, 1954}

\begin{tabular}{|c|c|c|c|c|c|}
\hline \multirow[b]{2}{*}{ Farm Type } & \multicolumn{3}{|c|}{ Animal Units By Kind of Livestock } & \multirow{2}{*}{$\begin{array}{l}\text { Total Animal } \\
\text { Units Per } \\
\text { Farm Type }\end{array}$} & \multirow{2}{*}{$\begin{array}{l}\text { Animal Units } \\
\text { Purchased by the } \\
\text { Average Farmer } \\
\text { Within Each } \\
\text { Farm Type }\end{array}$} \\
\hline & $\begin{array}{l}\text { Caftle } \\
\text { and } \\
\text { Calves }\end{array}$ & Hogs & Sheep & & \\
\hline Dairy & 1,577 & 62 & 2 & 1,641 & 2.0 \\
\hline Work-Off-Farm & 279 & 11 & 5 & 295 & 1.4 \\
\hline Livestock & 465 & $91 \dagger$ & 6 & 562 & 5.4 \\
\hline Poultry _-__ & 116 & 25 & 1 & 142 & 2.8 \\
\hline Grain & 39 & 3 & 2 & 44 & 1.1 \\
\hline General Farming ---- & 146 & 9 & 6 & 161 & 4.5 \\
\hline Vegetable & 18 & 13 & 1 & 32 & 1.0 \\
\hline Retired Workers & 2 & - & - & 2 & 0.2 \\
\hline Fruit - & 12 & - & - & 12 & 1.0 \\
\hline Unknown & 一 & - & - & - & 一 \\
\hline All Types & 2,654 & 214 & 23 & 2,891 & 2.2 \\
\hline
\end{tabular}

5 hogs, 7 An animal unit equals any of the following: 1 cow, 1 bull, 1 steer, 1 stag, 2 heifers, 5 calves,

$\dagger$ Adjusted for one respondent who purchased 1,920 animal units of hogs.

number and "unknown" type of farmers the least average number of animal units. At the 5 per cent level of significance, an analysis of variance indicated the purchases reported for dairy and livestock farmers averaged significantly more animal units than other types of farming. There were no significant differences in number of animals purchased between dairy and livestock farmers. Livestock farmers procured a significantly larger number of animal units than did grain, vegetable, fruit, retired workers and "unknown" farm types. Among all farm types except dairy and livestock, no significant differences were noted in the number of animal units purchased.

The data in Table 49 indicate that in general farmers in the Northeastern region purchased more than 60 per cent of their livestock from dealers and other farmers. In 1954, purchases from dealers ranked first, with 32 per cent of all animal units bought from this market agency (Table 50). Procurements from other farmers were second, accounting for 30 per cent of all animal units, and auction purchases ranked third, amounting to 20 per cent of all animal units bought. The data in Tables 49 and 50 indicate there is considerable variation in the number of livestock purchased from each source by type of farming. However, at the 5 per cent level of significance there is no significant difference in the number of animal units purchased from each of the sources. 


\begin{tabular}{|c|c|c|c|c|c|c|c|c|}
\hline$\underline{\underline{\mu}}$ & g & $\therefore$ & 888 & 웅요응으 & 8888 & 8888 & 888: & \\
\hline$\underbrace{0}_{0}$ & $\bar{\Sigma}$ & ì & 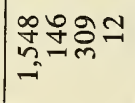 & 궘ํำ & 겁슴워 & 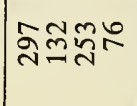 & 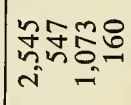 & 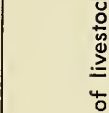 \\
\hline$\Leftrightarrow$ & 芯 & $\therefore$ & =6NO & NaOO & m000 & $0=+m$ & Nar- & $\frac{E}{\underline{z}}$ \\
\hline$\sum_{\substack{1 \\
\Leftrightarrow}}$ & 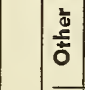 & io & mano & $0 \pm 00$ & $m_{-\infty}^{\infty} 0-0$ & ong & 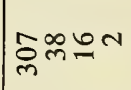 & : \\
\hline 든 둘 & है & 20 & møing & ㅊำ욤 & 경m & 음ำ는 & สุตูซ & $\frac{7}{10}$ \\
\hline 武武 & 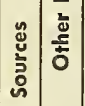 & io & ิํำ & ทำำ & 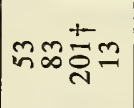 & 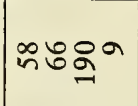 & 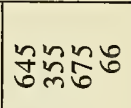 & ह \\
\hline 象芯 & & 2 & भत् & & mrno & 워는 & 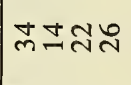 & ष्ठ \\
\hline อ른 & ดั๊ & ì & ڤ & $\stackrel{m}{m} \underset{-}{ }$ & $\pm \infty \stackrel{0}{ \pm}$ & 으눅움 & 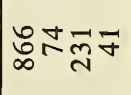 & \\
\hline$\sum_{1}^{6}$ & .ొ & 20 & mnno & Nูnoo & 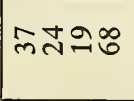 & ิํำกู & 즈ఃల్ & 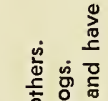 \\
\hline $\begin{array}{l}0 \\
\theta \\
{[}\end{array}$ & $\stackrel{5}{4}$ & $\dot{0}$ & $\overline{\mathrm{d}}^{-\infty}$ ino & $i^{+\infty}$ & گુำ & פฺn๓ & 융요 & 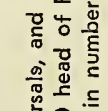 \\
\hline$\underset{0}{0}$ & $\frac{.}{\stackrel{n}{\leftrightarrows}}$ & $\circ$ & mooo & 0000 & 0000 & $m 000$ & 9000 & 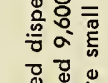 \\
\hline 是筫 & 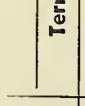 & $\dot{0}$ & Fo00 & 0000 & $=000$ & 8000 & $\frac{\infty}{N} 000$ & 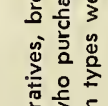 \\
\hline 果 & 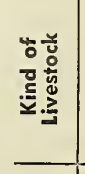 & & 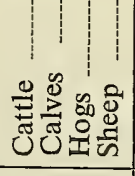 & 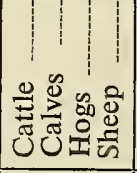 & 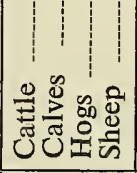 & 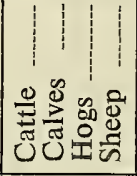 & 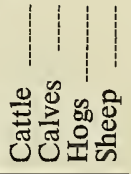 & 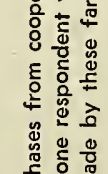 \\
\hline 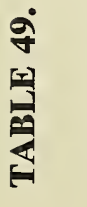 & 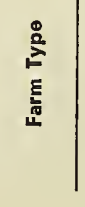 & & 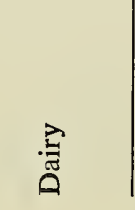 & 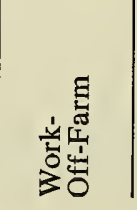 & 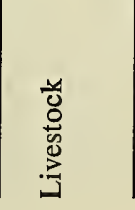 & 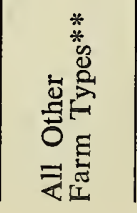 & 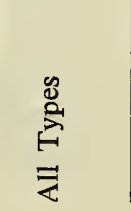 & 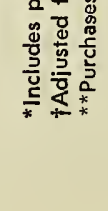 \\
\hline
\end{tabular}




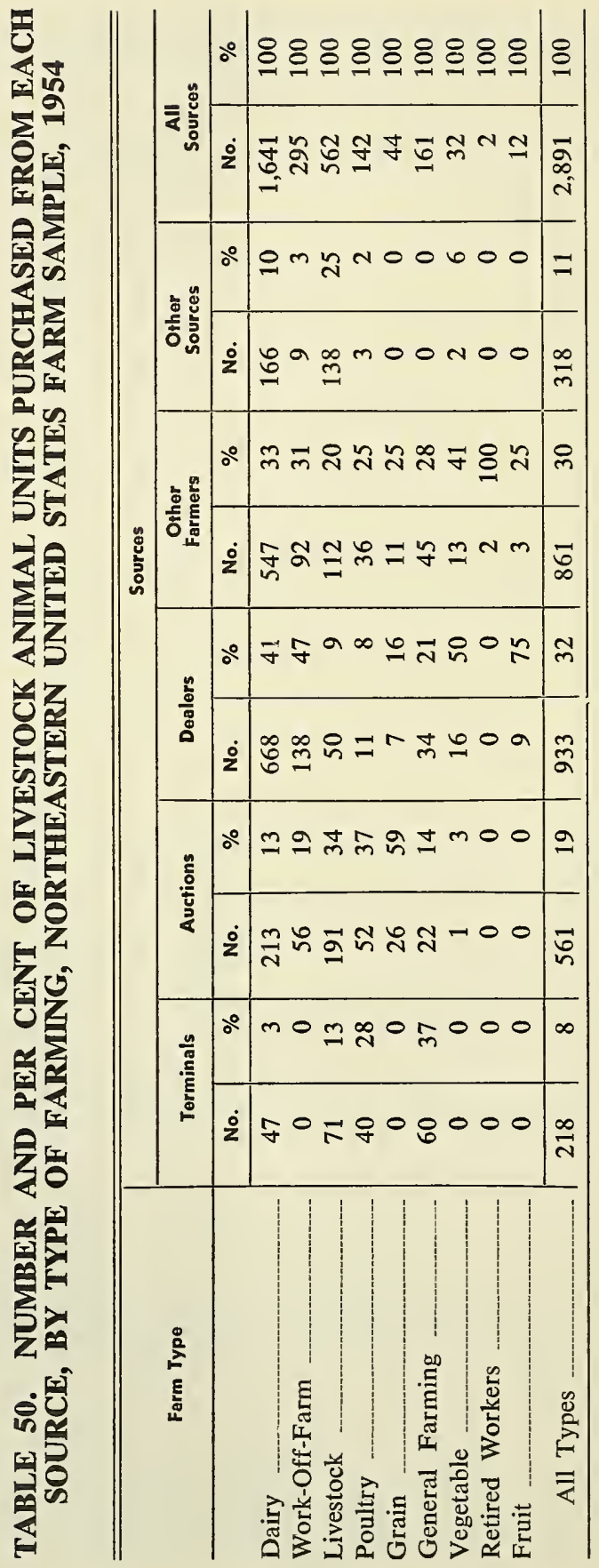


In general producers buy livestock for herd replacements or feeding. There are also other reasons, such as beginning a livestock enterprise, public relations, pets, speculation, etc., but these are usually minor and generally account for relatively small proportions of livestock bought by producers. During 1954, 96 per cent of all cattle and calves, 88 per cent of all hogs, and 70 per cent of all sheep bought by Northeast producers were purchased for herd replacements or feeding (Table 51). About 85 per cent of the dairy-type cattle and calves were bought for replacements, while the same percentage of beef-type cattle and calves were bought for feeding. More than 75 per cent of the hogs were bought for feeding, and a majority of the sheep were bought for replacements.

Almost 80 per cent of all respondents indicated a preference for raising their own replacements (Table 52). The 13 per cent who indicated a preference for buying replacements must be the ones making the purchases in Table 57 or else the 80 per cent are not doing what they prefer to do. The most commonly given reason for preferring to raise replacements was "knowledge of health and animal characteristics" (Table 53). "Obtain better stock" and "cheaper to raise than to buy" were ranked second and third, respectively. Other minor reasons concerning health, stock selection, and cost were given, but most of these were variations of the three major reasons. Those farmers preferring to buy their replacements gave as reasons for this choice two of the major reasons listed by those farmers preferring to raise their replacements. "Cheaper to buy than to raise" and "buy better stock than those owned" were ranked first and second, respectively (Table 54). "Lack of space" and "convenience" were also listed as reasons for buying replacement stock.

Since dairy-type cattle and calves are bought primarily for herd replacements, farmers should take as many precautionary steps as possible to guard against buying poor producers or diseased animals. As a rule of thumb, farmers should never buy replacement stock for which health and production records are not known. In practice, however, this rule cannot always be followed. It was noted in an earlier section that in the Northeast relatively few livestock were sold where such information was made available. One method of obtaining health and production data is by knowing the owners of livestock being considered as replacements. It is assumed that if a farmer knows the owner, he will be in a position to obtain the necessary information. Of course, this does not mean that the information received will be written, complete, and accurate. In fact, it may be oral, incomplete, and untrue. Yet, even with these shortcomings a pre-purchase check should be made, for some information is often better than none. 


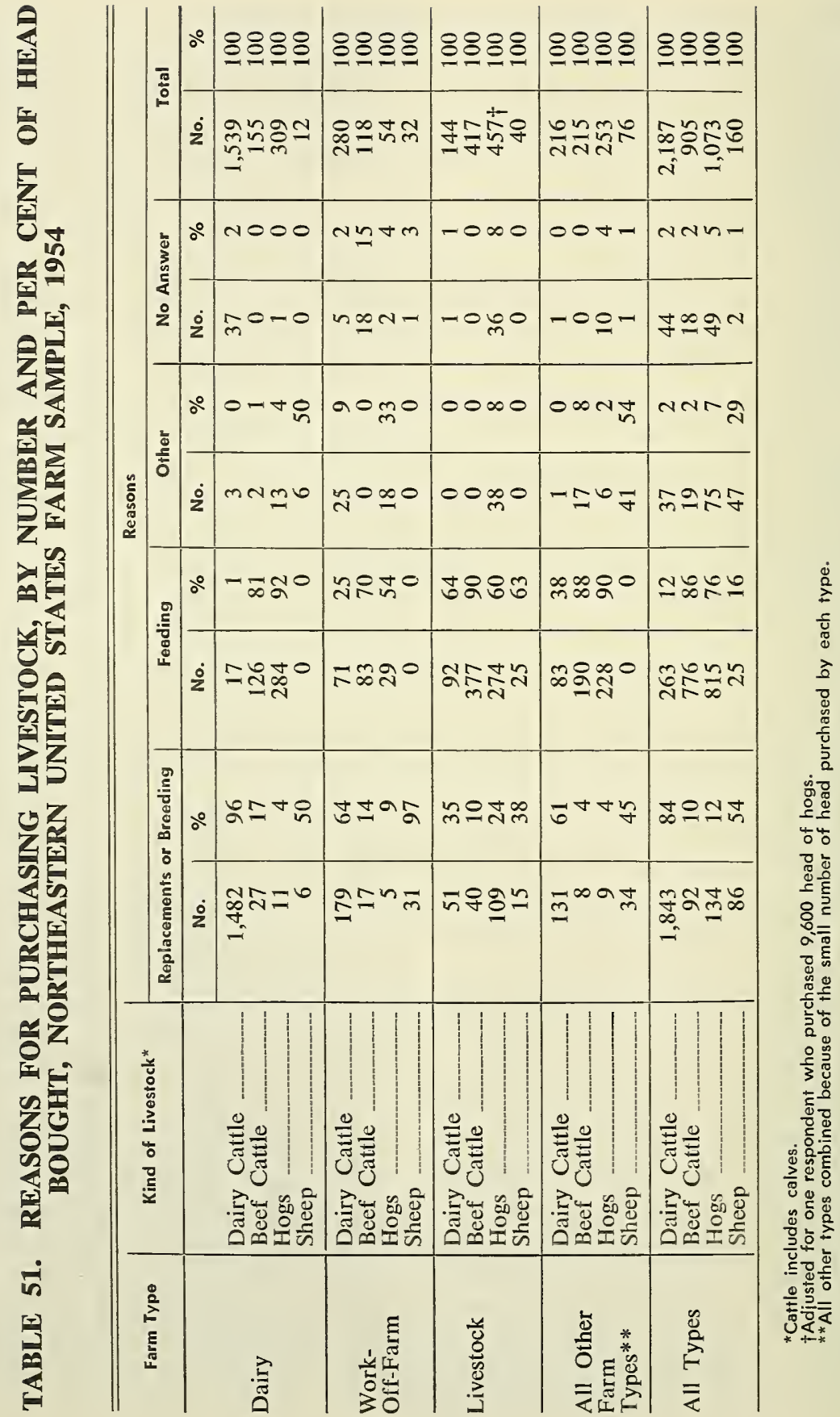




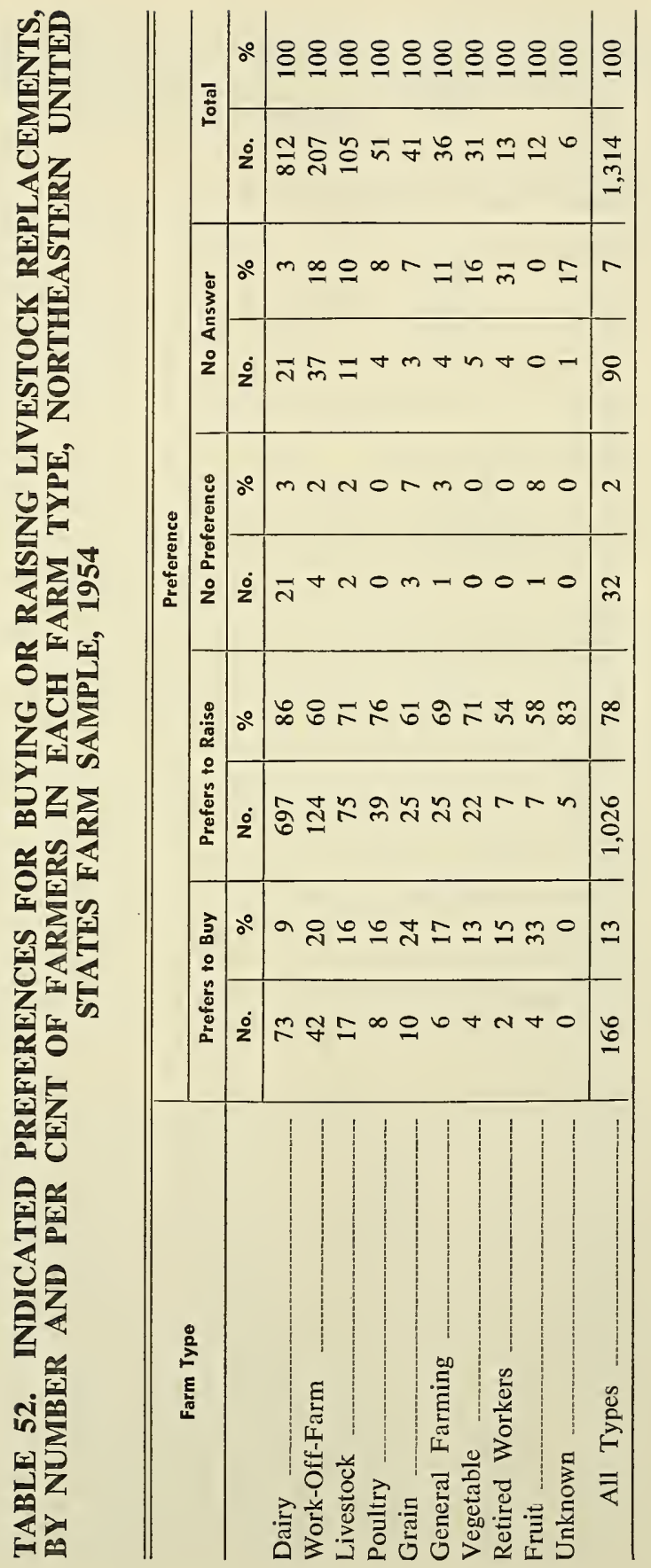




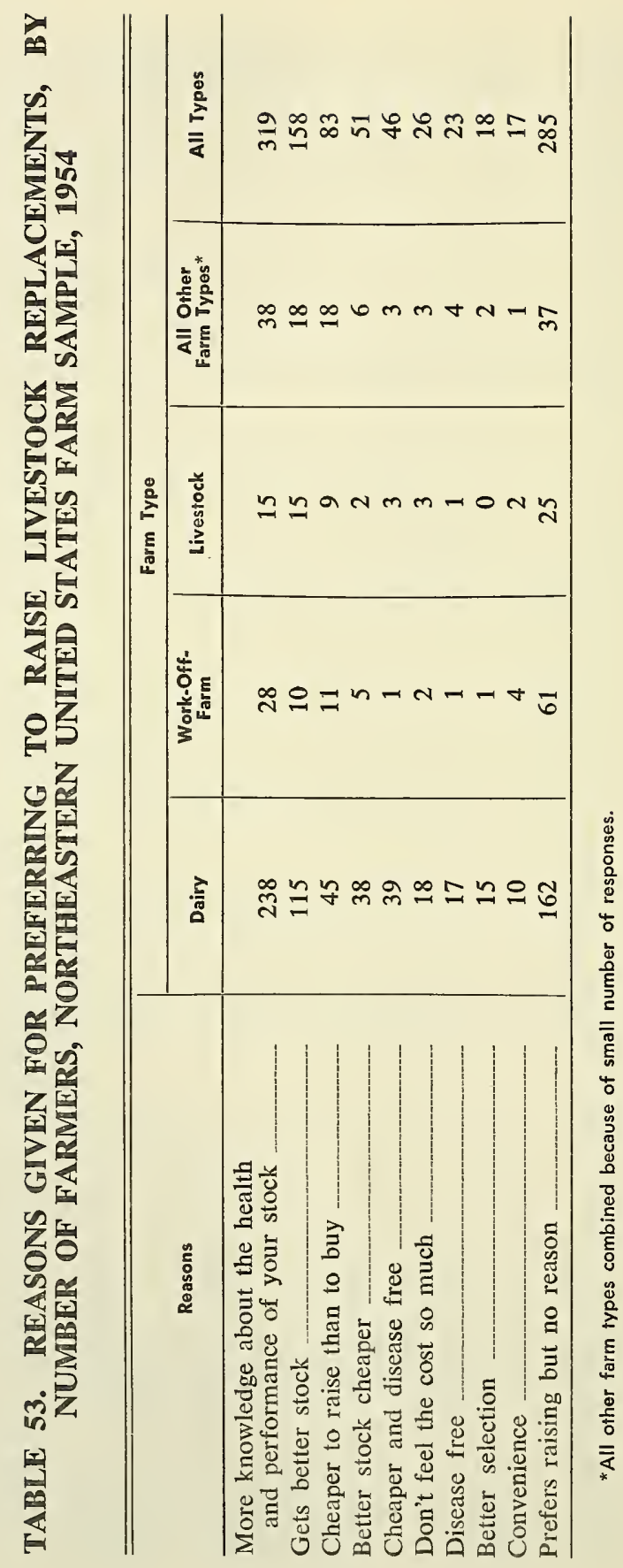




\section{TABLE 54. REASONS GIVEN FOR PREFERRING TO BUY RE- PLACEMENT LIVESTOCK, BY NUMBER OF FARMERS, NORTH- EASTERN UNITED STATES FARM SAMPLE, 1954}

\begin{tabular}{l|r|r|c|c|c}
\hline \multicolumn{1}{c|}{ Reasons } & \multicolumn{5}{|c}{ Farm Type } \\
\cline { 2 - 6 } & Dairy & $\begin{array}{c}\text { Work-Off- } \\
\text { Farm }\end{array}$ & Livestock & $\begin{array}{c}\text { All Other } \\
\text { Farm Types* }\end{array}$ & All Types \\
\hline $\begin{array}{l}\text { Cheaper to buy than to raise } \\
\text { Buy better stock }\end{array}$ & 40 & 10 & 6 & 12 & 68 \\
$\quad$ than those owned & 13 & 7 & 4 & 4 & 28 \\
Takes too long to raise them & 5 & 6 & 2 & 2 & 15 \\
Not enough help or space & 10 & 0 & 1 & 3 & 14 \\
$\quad$ to raise them & 2 & 7 & 1 & 2 & 12 \\
$\begin{array}{l}\text { Does not breed } \\
\text { Convenience }\end{array}$ & 3 & 4 & 1 & 1 & 9 \\
$\begin{array}{l}\text { Prefers to buy but } \\
\text { no reason given }\end{array}$ & 0 & 8 & 2 & 10 & 20 \\
\hline
\end{tabular}

*All other farm types combined because of small number of respondents.

\section{KNOWLEDGE OF PAST HISTORY-INSPECTION}

At the time they purchased livestock, Northeast producers knew the owners of one-half of the dairy-type cattle and calves purchased, 43 per cent of the hogs, 55 per cent of the sheep, and 16 per cent of the beef-type cattle and calves (Table 55). Since the previous owner was known for only one of two dairy replacements bought, it precluded buyers from knowing or obtaining information from original owners concerning the health and production for half of all dairy replacements purchased, and these two factors were given as primary reasons for preferring to buy replacements. This tends to indicate that the reasons listed for preferring to buy livestock may not always be adhered to in purchasing stock.

Even though farmers know the owners of livestock before purchasing them, it does not follow that they will obtain production records for the animals or make arrangements to have them inspected by veterinarians. The data in Table 56 show that annual milk production records were known for only 6 per cent of the dairy cows purchased by dairy farmers, and butterfat records were known for only 5 per cent. At the same time only 40 per cent of all cattle and calves bought by dairy farmers were known to have been veterinary-inspected (Table 57). The proportion of dairy cows inspected was not ascertained, but it could be lower than 40 per cent since that includes all cattle and calves. Thus, the owners of dairy cattle and calves were known for half of the cattle and calves bought, production records were obtained for about 5 per cent of the cows, and approximately 40 per cent of the dairy cattle and calves were 


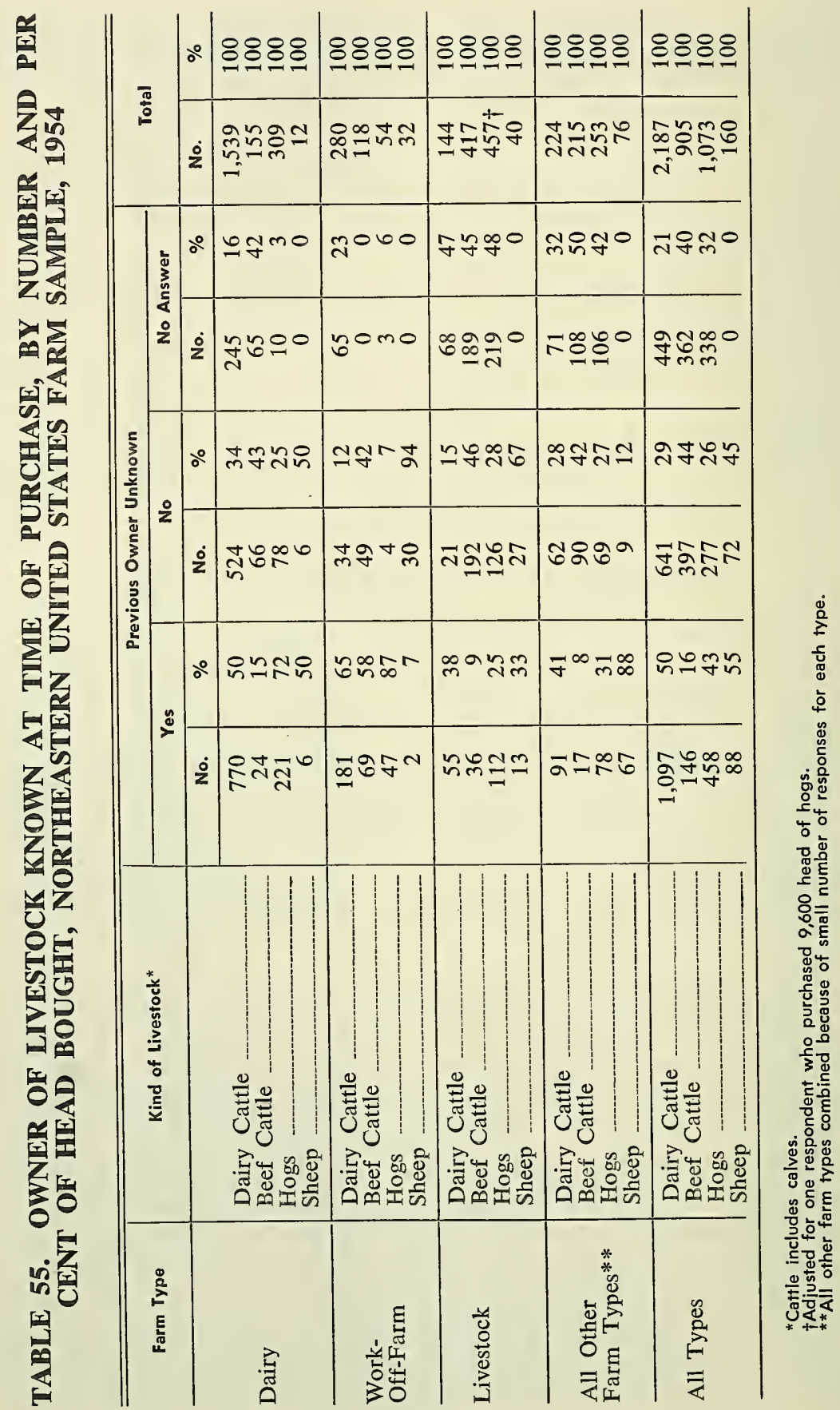




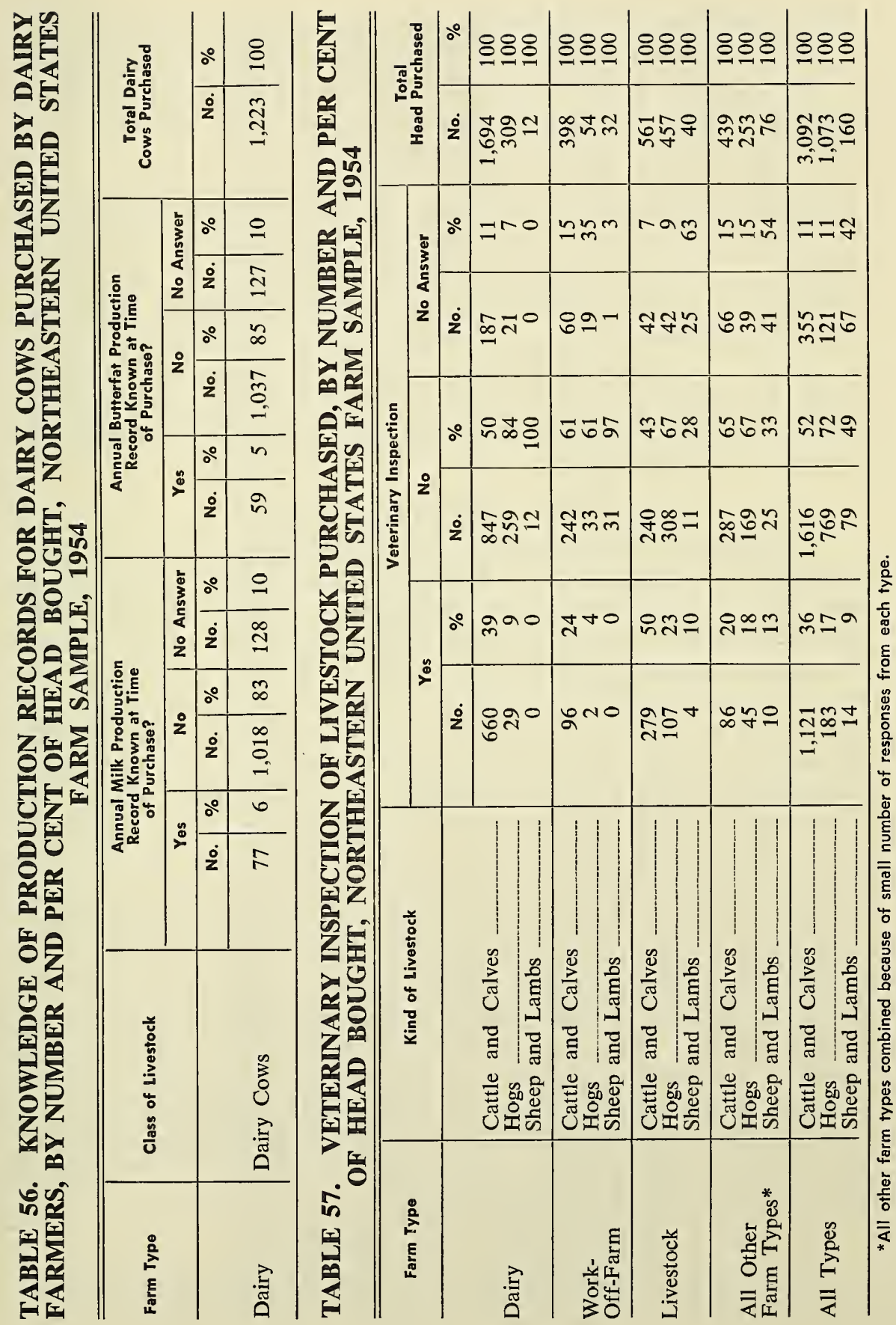


veterinary-inspected. In conclusion, it appears that many Northeast farmers are buying replacements on a "hit or miss" basis when they should be insisting upon written records for all livestock purchased. Furthermore, their actual buying practices are not in complete agreement with their stated reasons for buying replacements.

Veterinary inspection of livestock in the Northeast usually occurs at livestock auctions and not on farms. The data in Table 58 point out the rather large proportion of farmers who do not know about the availability of such services at livestock auctions near their farms. Since many farmers do not know whether there is or is not inspection at local auctions, the percentages in Table 57 may understate the proportion of livestock which are inspected. At any rate, the high proportion of farmers having no knowledge about veterinary services at auctions is indicative of the lack of producer knowledge about services available at auctions, terminals, and other markets.

\section{AGE OF LIVESTOCK PURCHASED}

Since most of the livestock purchased by producers were to be used either for herd replacements or else fed for some period and sold at a later date, the ages of livestock when purchased were associated with their intended use. Dairy herd replacements usually fell within two age groups when bought; calves under three months of age and cattle over two years of age (Table 59). The latter group ranked first, accounting for 56 per cent of dairy animals purchased, while calves under three months accounted for 20 per cent. One- to two-year-old heifers ranked third, accounting for 12 per cent of all dairy animals purchased. Almost all of the beef-type cattle and calves were over 6 months of age when purchased. The largest proportion (51 per cent) was between the ages of one and two years, and the second-ranking age group (31 per cent) was 6 months to 1 year. Practically all hogs were bought for feeding purposes. In addition to farmers who bought feeder pigs and later sold them as slaughter hogs, many farmers bought one or two hogs each year for home consumption. A large number of these hogs were at or very near slaughter weights when purchased. Feeder pigs under 3 months of age accounted for almost two-thirds of all hogs purchased, and hogs 3 months to 1 year of age made up one-fourth of the hogs purchased (Table 59). Although the number of sheep bought was relatively small, most of them were bought for replacements. Approximately 72 per cent of the sheep were 1 year old or more when purchased.

\section{SEASONALITY OF PURCHASES}

In 1954, June, September, October, and November were the months when Northeast farmers purchased the greatest number of livestock (Table 


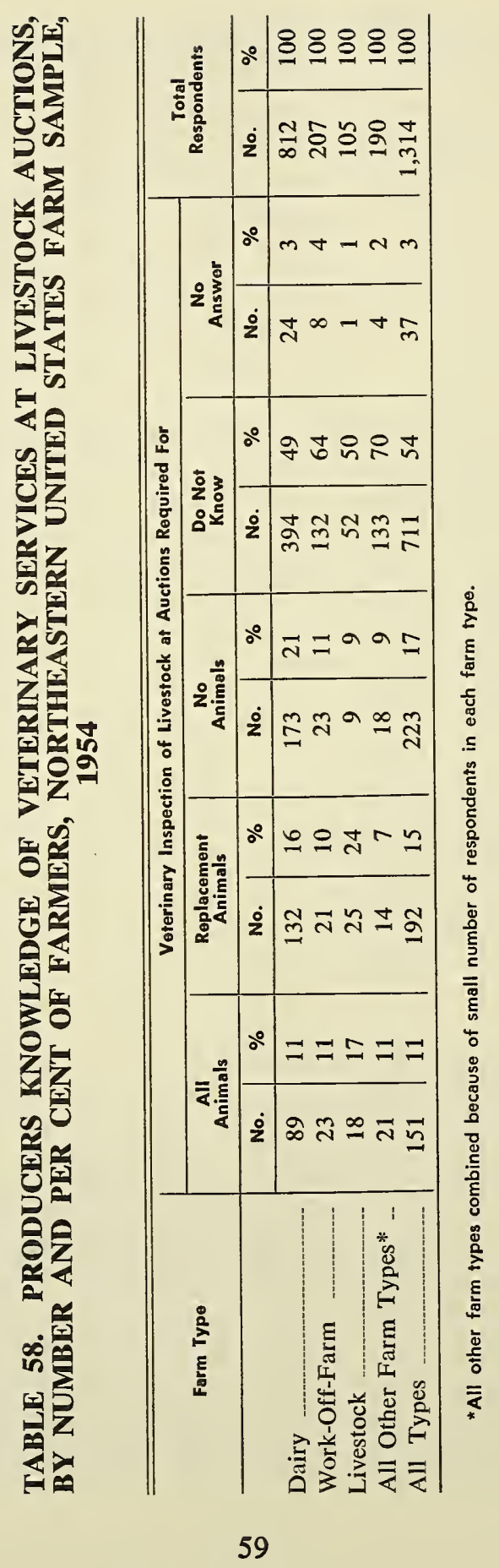




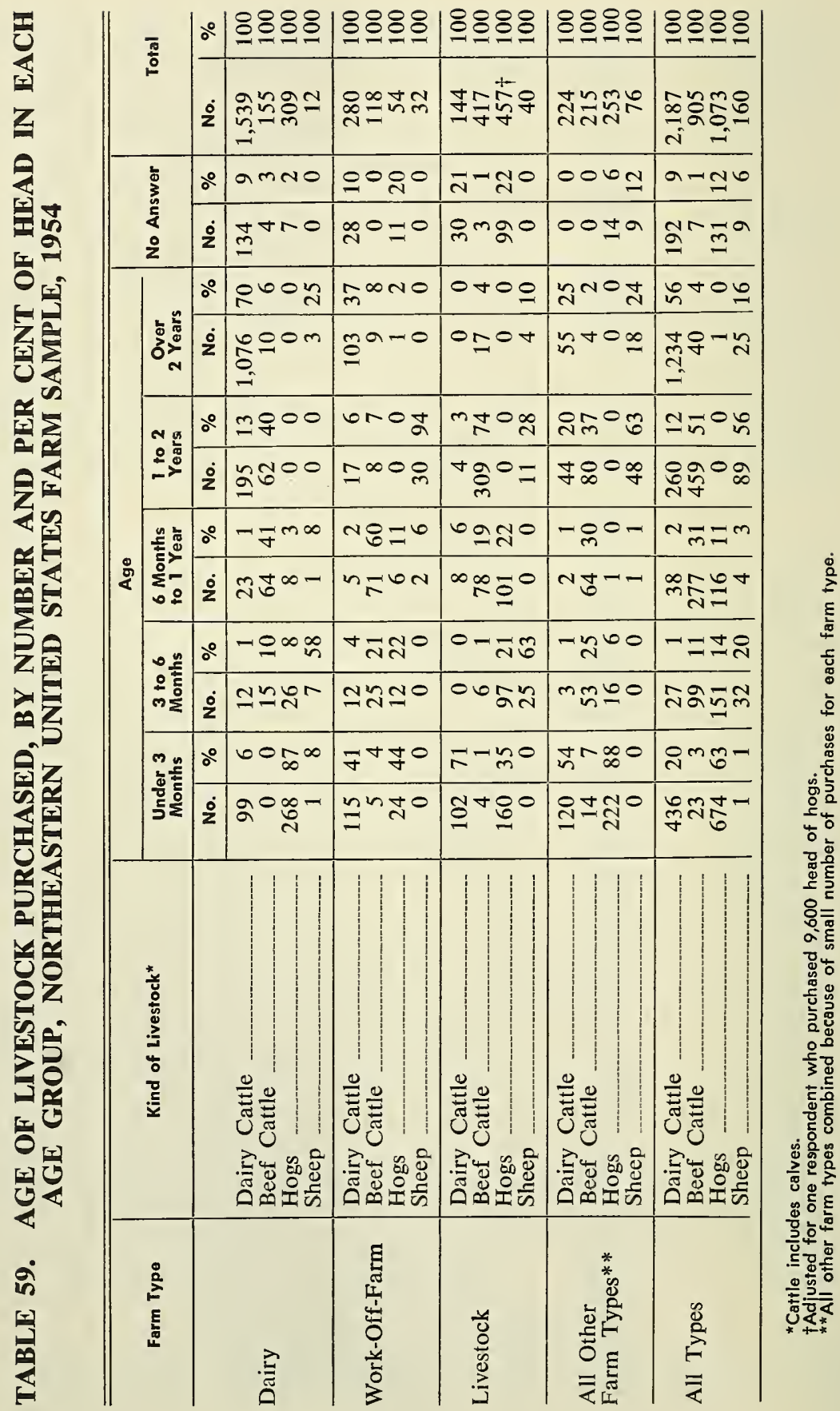


60 ). October was the leading month and January the lowest month in number of lots purchased. Beginning with an annual low in January, livestock purchases generally increased through the month of June. During June the number of livestock purchased reached a second, but minor peak for the year. In the month of July purchases decreased substantially, but from this low they increased at an increasing rate to an annual peak during the month of October. Following the October peak, purchases declined rapidly during November and December. From the data gathered, it was not possible to determine if this was the normal cycle followed in purchasing livestock. However, certain indicators tend to support the 1954 cycle as one we would normally expect.

Since dairy-type farmers bought 71 per cent of all cattle and calves purchased and two-thirds of all livestock lots purchased, factors which influenced their seasonal buying decisions had a great effect on the shape of the annual buying cycle. During the fall months economic incentives are generally higher, furnishing added inducement for dairy farmers to buy livestock, especially dairy cows. With higher seasonal prices for milk most farmers would like to either maintain or increase production. At this time of year, however, pastures are not as good as they were in earlier months and production per cow is generally lower. Therefore, to take the most advantage of higher milk prices more cows must be added to the herd, and one way to do this is to buy them.

Base excess plans also furnish added inducement for farmers to increase livestock procurements during the late summer and fall months. During these months milk bases are established, and these bases partially determine the total amount of income a farmer will receive from next year's milk sales. Thus, there is an economic incentive to increase or at least maintain production during the fall months, and many farmers do this by purchasing dairy cows.

\section{LOT SIZE}

As explained in the section on livestock sales, the number of animals in each lot bought or sold varies considerably and depends upon many factors. The most typical lot size for all livestock bought was one head (Table 61). Approximately 82 per cent of the cattle and calves were purchased in lots containing five or fewer head. Hog and sheep lots were slightly larger than those of cattle and calves, with 67 per cent of the hog and 71 per cent of the sheep lots containing five or fewer head. Since hog and sheep lots were relatively small in number, all lots containing five or fewer head were combined, and for this reason the number of lots containing one head is not specifically shown in Table 61. For all farm types, the average number of head in all lots of cattle and calves purchased was 4.1. For hogs and sheep, the numbers were 8.3 and 6.7, respectively. 


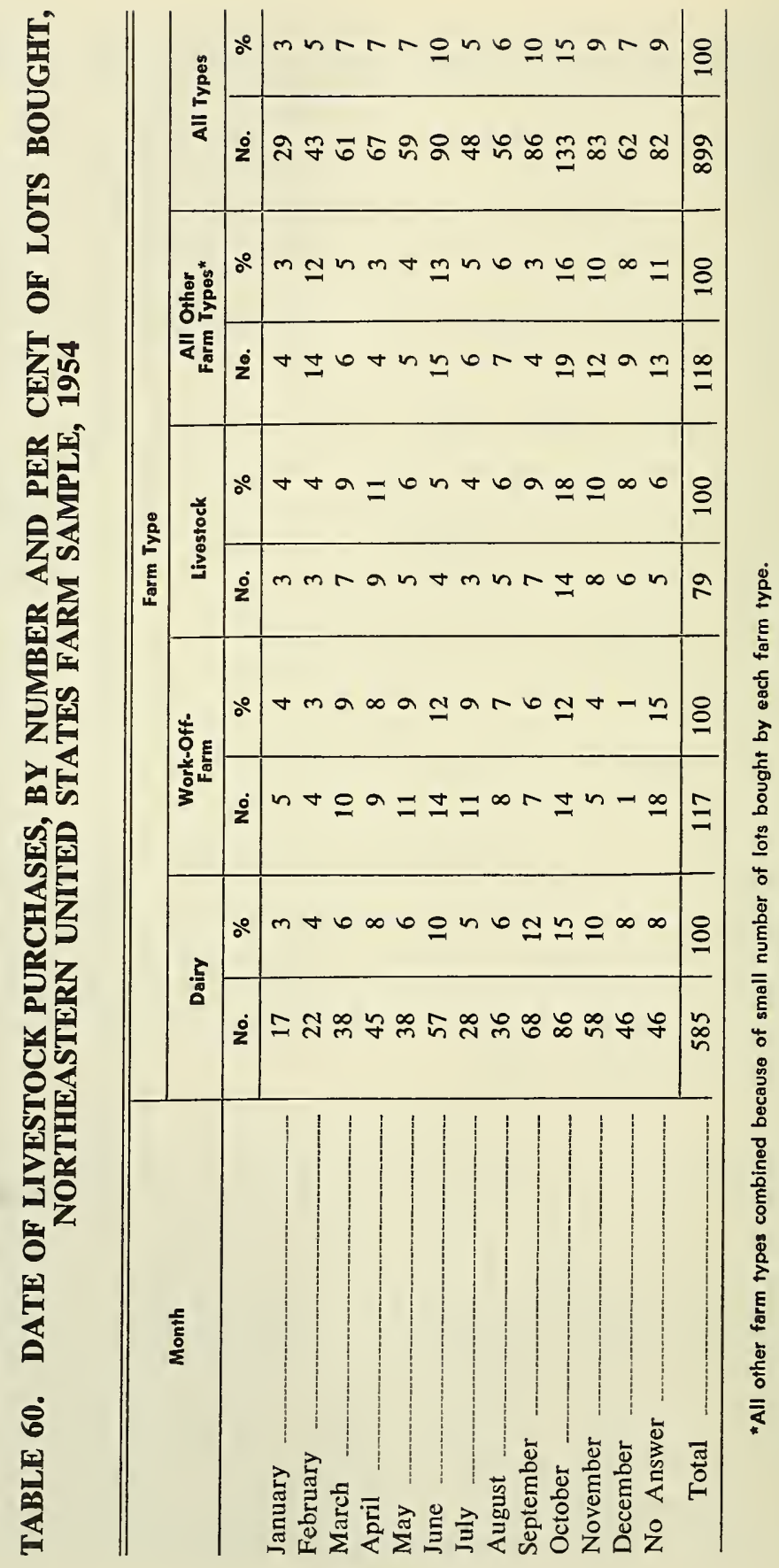




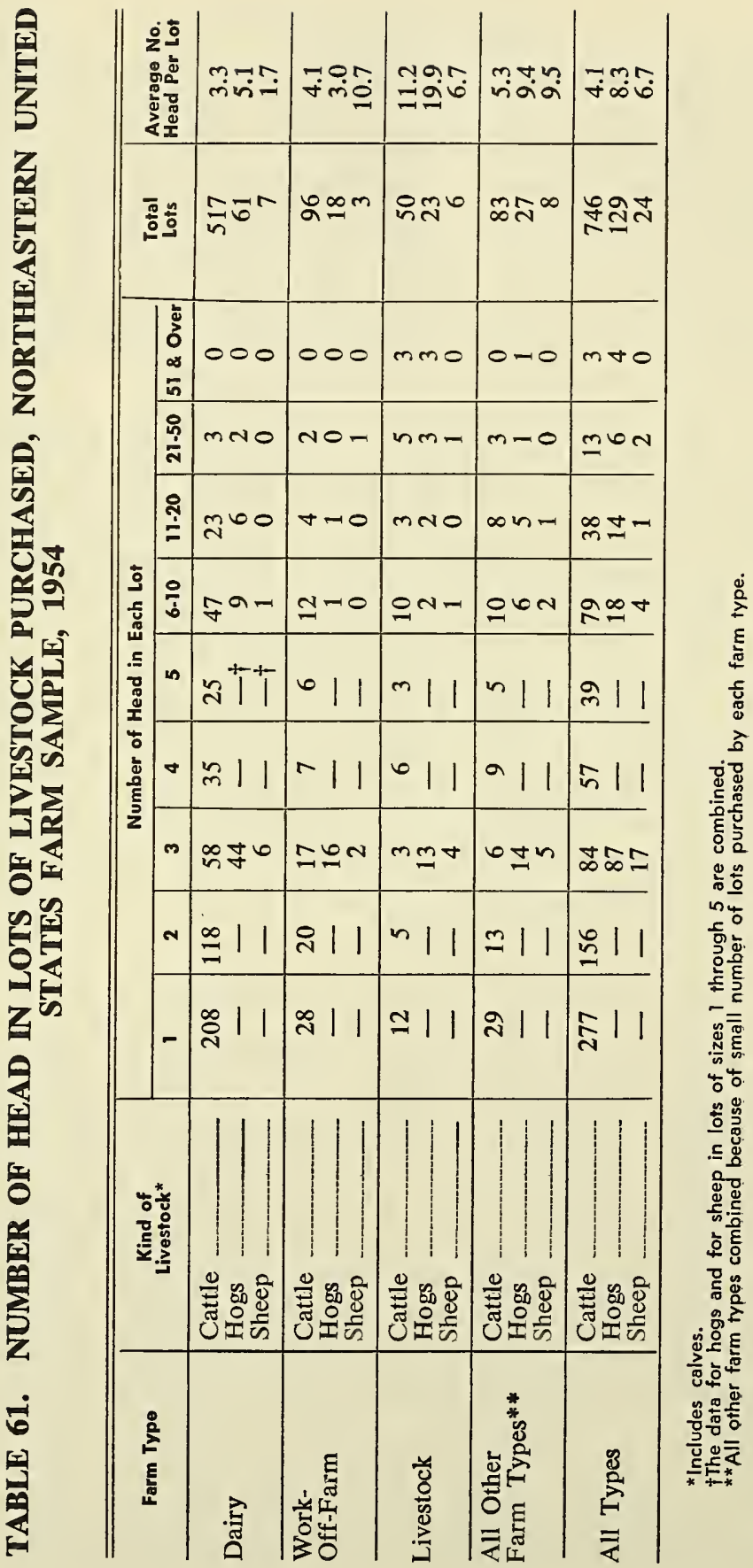




\section{TYPE PURCHASES}

Historically, and at the present time, most livestock trading at public markets is done on a cash basis. If credit is necessary to complete purchases, livestock farmers usually borrow from friends, relatives, bankers, and other lending institutions. The only livestock market agency that uses significant amounts of credit is livestock dealers. Merchant noted that during 1953-1954, more than 55 per cent of Northeastern livestock dealers extended varying amounts of credit. ${ }^{8}$ Extension of credit is no doubt one of the reasons why the number of dealers in this region has not declined as rapidly as it has in other regions.

Credit purchases during 1954 accounted for only 5 per cent of all cattle and calf lots bought (Table 62). Although small in number, none of the hog and sheep lots was obtained by using credit. In the absence of empirical data, it is not possible to assess the livestock credit needs of farmers in the region. It may or may not be a limiting factor for some farmers. This study merely determined the number of livestock bought by using credit, and this number is exceedingly small.

Within the region, replacement livestock is generally bought and sold by the head, and slaughter animals are sold by the pound. Considering that farmers purchase largely replacement stock, the large percentage of livestock bought by the head, as shown in Table 62, is not at all surprising. Another institutional factor contributing to the importance of "head" purchases is dealers. Since dealers are the major source of replacement animals, and very few dealers own scales, many farmers have no choice except buying by the head.

\section{HEALTH OF LIVESTOCK PURCHASED}

As stated earlier, most producers expressed a preference for raising their own replacements, and a major reason influencing this preference was the securing of healthy, disease-free livestock. If these farmers did in fact raise their replacements, it is logical that those animals purchased must have been bought by those producers indicating a preference for buying replacement livestock. With most of the animals intended for herd replacements, farmers should have taken all necessary precautions to avoid diseased animals. Therefore, a high rate of disease or other trouble among the stock purchased would indicate that farmers raising their own replacements might be using the best alternative in obtaining replacements.

Those farmers who bought livestock during 1954 stated that, of the animals purchased, one of every 5 cattle and calves, one of every

8 Merchant, Charles H., Livestock Dealers' Operations in Northeastern United States, Maine Agricultural Experiment Station Bulletin 555, University of Maine, May 1957, p. 22. 


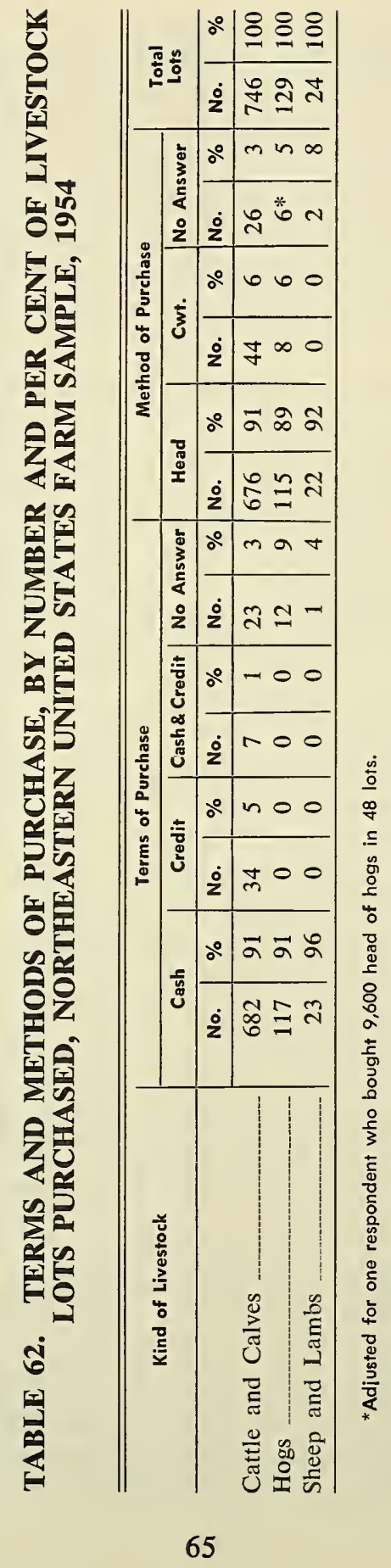


5 sheep, and one of every 50 hogs suffered illness or other trouble, such as failure to breed (Table 63). Livestock purchased by livestock, dairy, and work-off-farm type producers had the highest rates of illness or other trouble. The highest rate of illness or other trouble among cattle and calves occurred in the purchases made by work-off-farm producers. Among the sheep purchased, 80 per cent of those bought by livestock farmers had some type of illness or other trouble. The rates among sheep, cattle, and calves appear to be relatively high and if these are normally occurring rates, farmers who buy replacements might well consider raising them.

\section{SATISFACTION WITH LIVESTOCK PURCHASED}

It would be expected that farmers who purchased animals which were unhealthy or had other troubles would not be entirely satisfied with their purchases. However, the data in Table 63 indicate that farmers bought 609 cattle and calves that suffered illness or other trouble, but dissatisfaction was registered with only 247 cattle and calves. Apparently the sickness suffered in many cases was not too severe and was of short duration. It is possible that some farmers said they were satisfied when they were not.

By source of livestock, the data in Table 64 indicate that livestock purchased from farmers had the lowest rate of illness or other trouble, and those bought from minor sources had the highest rate. Purchases from other farmers had such an extremely low rate of illness or other trouble (half the rate of the next lowest source) that farmers should give this source a lot of consideration when deciding where to obtain replacements. Satisfaction with livestock purchases, by source of livestock, tended to be highest with terminal and minor sources and lowest with auctions and dealers (Table 64). It is difficult to understand why farmers displayed dissatisfaction with dealer purchases. Dealers likely provided the maximum amount of service and the animals bought from them had the second lowest rate of illness. It may be that the production of cows bought from dealers was not up to farmers' expectations, or producers may have felt that the prices they paid for the animals were too high.

\section{Farmers' Attitudes on Their Marketing Problems}

"What are your major marketing problems?" Responses to this question were so varied and numerous that they defy neat and precise classification. At first glance, many of the answers appear to be overlapping and express the same problem. For example, "low prices," "lack of competition," and "taking cut in prices" seem to be statements which 


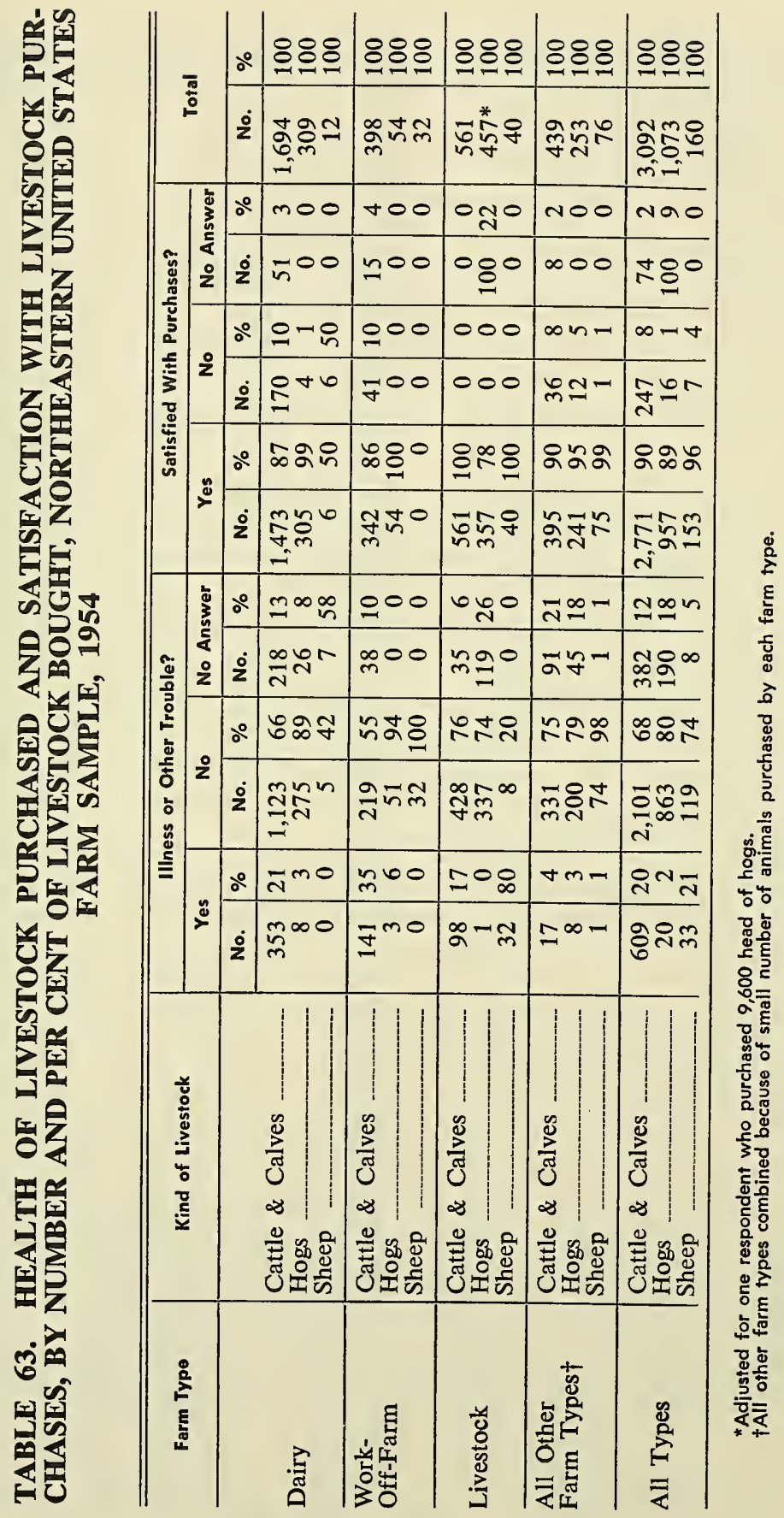




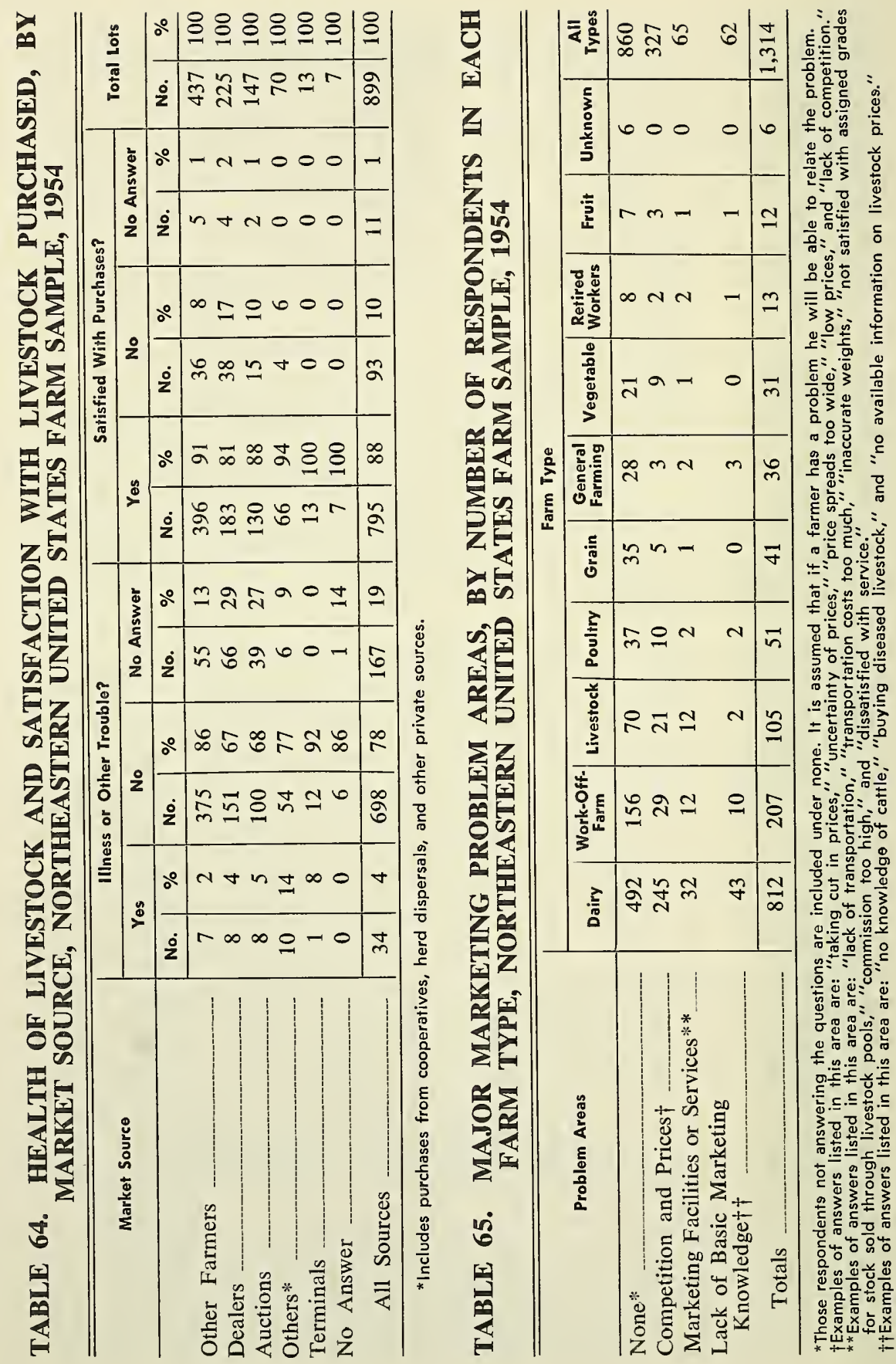


have essentially the same meaning. It is possible, however, that some producers would complain of low prices regardless of competition and some would bemoan the absence of competition if prices were abnormally high. This is one example pointing out interpretive problems involved in categorizing answers to open-ended questions.

One manner of classifying "stringbean" data is to make separate categories for all differently stated responses. This procedure was followed, and although it reduced the error in coding and classifying, it resulted in 30 separate categories. Since many of these categories seemed to be different shades of the same problem; and the list was so lengthy that it was unwieldy, it was decided to forsake this method of coding and classifying.

Another way of processing data of this type, and the one followed in this instance, is to combine into one problem area all those responses which have a bearing on one major topic. In other words, "low prices," "taking cut in prices," "price spreads too wide," "lack of competition," "uncertainty of prices," and other answers dealing with prices and competition are combined in one category- "competition and prices." It was this boiling-down process that led to the four major categories in Table 65 .

The category "none" in Table 65 combines those respondents who stated "none" with those who gave no answer. It is assumed that if a producer has a problem, he is capable and willing to express it, otherwise, he has no problem. If this presumption is correct, it can be seen that approximately two-thirds of the producers indicated they had no marketing problems. If those who did not answer the question are excluded, the proportion of producers who said positively that they had no marketing problems is still greater than half.

The findings indicate that approximately one-fourth of the respondents have "felt problems" in the area of prices and competition. It is well known that in certain areas of the Northeast, farmers essentially have one market outlet for their cull dairy cows and calves - livestock dealers. Of course, there are other market outlets, but for many farmers the time and expense necessary to reach them prohibits their use. In these circumstances there are likely some instances when farmers are faced with a less than purely competitive market. No doubt, these occasions are marked by livestock prices which are lower than they would normally be if effective competition prevailed. However, as noted by Tompkins and Tuthill, not all dealers make a positive income; some never see the rainbow, much less the end of it.? 
Another 5 per cent of the producers had problems which generally dealt with what they felt were inadequate market facilities and services. Some of the responses indicated that certain facilities such as scales and trucks were not available, whereas others stated that the facilities available were not adequate or inaccurate and cost too much for their use. Marketing services such as grading, weighing, and transporting were also criticized by some of these farmers. Since the number of farmers listing complaints in this problem area was rather small and their problems showed no really strong degree of concentration, these problems are likely of small import. 
Ear 0

BIGOS-JOHNSTON-WTTHROW, BECKLEY 
3

of

\%

eosisis

8 